UNIVERSIDADE DE SÃO PAULO

FACULDADE DE FILOSOFIA, LETRAS E CIÊNCIAS HUMANAS

DEPARTAMENTO DE LETRAS CLÁSSICAS E VERNÁCULAS

PROGRAMA DE PÓS-GRADUAÇÃO EM ESTUDOS COMPARADOS DE LITERATURAS DE LÍNGUA PORTUGUESA

CIRO MARTINS LUBLINER

\title{
Fragmento, Escrita do Desastre \\ e Testemunhos da Desrazão
}

versão corrigida

São Paulo

2016 
UNIVERSIDADE DE SÃO PAULO

FACULDADE DE FILOSOFIA, LETRAS E CIÊNCIAS HUMANAS

DEPARTAMENTO DE LETRAS CLÁSSICAS E VERNÁCULAS

PROGRAMA DE PÓS-GRADUAÇÃO EM ESTUDOS COMPARADOS DE LITERATURAS DE LÍNGUA PORTUGUESA

Fragmento, Escrita do Desastre

e Testemunhos da Desrazão

Ciro Martins Lubliner

Dissertação de Mestrado apresentada ao Programa de Pós-Graduação em Estudos Comparados de Literaturas de Língua Portuguesa da Faculdade de Filosofia, Letras e Ciências Humanas da Universidade de São Paulo para obtenção do título de Mestre em Letras.

Orientador: Prof. Dr. Maurício Salles Vasconcelos<smiles>CC(C)(C)OC(C)(C)C</smiles>

versão corrigida

São Paulo 
Nome: LUBLINER, Ciro Martins

Título: Fragmento, Escrita do Desastre e Testemunhos da Desrazão

Dissertação de Mestrado apresentada ao Programa de Pós-Graduação em Estudos Comparados de Literaturas de Língua Portuguesa da Faculdade de Filosofia, Letras e Ciências Humanas da Universidade de São Paulo para obtenção do título de Mestre em Letras, área de concentração de Estudos Comparados de Literaturas de Língua Portuguesa

Aprovado em:

Banca Examinadora

$\operatorname{Prof}(\mathrm{a}) . \operatorname{Dr}(\mathrm{a})$.

Instituição:

Julgamento:

Assinatura:

Prof(a). Dr(a).

Instituição:

Julgamento:

Assinatura:

$\operatorname{Prof}(\mathrm{a}) . \operatorname{Dr}(\mathrm{a})$.

Instituição:

Julgamento:

Assinatura: 
a M.B. - constelação inominável à amizade e aos bons encontros - eternas moradas 


\section{AGRADECIMENTOS}

À minha família, em especial a Sandra, Marcus, Caio, Theo e Bianca (é certamente um privilégio poder dizer que além de meus pais e meus irmãos, vocês são pessoas fascinantes);

Ao Professor Maurício Salles Vasconcelos, pelo extremo companheirismo e cumplicidade durante todo o período de orientação;

A Hiro Ishikawa, pela afinidade e afetividade fraterna e artística, na composição de Fukushima mon amour;

A Profa. Dra. Aurora Fornoni Bernardini, Prof. Dr. Gabriel José Corrêa Mograbi e Profa. Dra. Annita Costa Malufe, presenças bastante valiosas nas bancas de defesa e qualificação;

A Amanda Mendes Casal e Eclair Antonio Almeida Filho, pela generosidade e confiança em mim depositada para o envio de trabalhos, principalmente da tradução para L'Écriture du Désastre;

A Carla Castellotti, por ter me oferecido, de maneira tão gentil e sensível, o raro Hospício é Deus;

A Yuri, pela descoberta de novos encantamentos;

Agradeço finalmente aos meus amigos, sem os quais a vida não seria grande coisa: Alessandro, Anike, Caio, Danilo, Douglas, Gabriel, João, Lucas, Mariana, Marcos, Patrícia, Paula, Paulo, Stocco e Tiago. 
LUBLINER, C. M. Fragmento, Escrita do Desastre e Testemunhos da Desrazão. 2016. 122 f. Dissertação (Mestrado) - Faculdade de Filosofia, Letras e Ciências Humanas, Universidade de São Paulo, 2016.

\section{RESUMO}

Esta pesquisa pretende colocar em diálogo, em um movimento de mútua iluminação, parte dos conceitos expostos no livro L'Écriture du Désastre de Maurice Blanchot e da produção de um grupo de escritores brasileiros, reunidos aqui na forma de uma dita "comunidade da desrazão". Partiremos inicialmente dos estímulos em Blanchot para a prática de uma escrita fragmentária que se fará posteriormente presente no desastre e nos testemunhos da desrazão. Estas referências se baseiam, sobretudo, nos pensamentos de dois filósofos alemães: F. Schlegel e F. Nietzsche. Após a visitação da potência do fragmento na escrita, iremos diretamente ao levantamento de uma espécie de "composição alquímica" que parece haver no desastre blanchotiano. Isto será feito na identificação de alguns conceitos que pairam sobre ele, na formação de um corpo, molecularização e substancialização do desastre. Como exemplo para esta corporificação utilizaremos o filme Hiroshima mon amour de Alain Resnais, marcador de uma fissura no século XX através do acontecimento da barbárie atômica. Reuniremos então, por meio do conceito de comunidade tal qual colocado pelo filósofo francês Jean-Luc Nancy, autores da literatura brasileira que produziram escritos provenientes de estados de desatino, tendo parte de seus testemunhos registrados durante ou após períodos de internações psiquiátricas. Estes autores serão: Lima Barreto, Maura Lopes Cançado, Torquato Neto, Renato Pompeu e Rodrigo de Souza Leão. Por conta da carga confessional que muitos destes textos apresentam, nos apoiaremos ainda - para uma análise mais profunda na relação entre a ficção e o real - no pensamento quanto ao testemunho proposto por Jacques Derrida. Buscaremos também vislumbrar como os elementos da alquimia do desastre operam nestes escritos. Finalmente, veicularemos textualmente o trabalho poético-audiovisual por nós realizado Fukushima mon amour, expositor das diferenças e transmutações dos tempos através da mediação do desastre e da desrazão na arte produzida a partir de desdobramentos provenientes do acidente nuclear.

Palavras-Chave: Escrita do Desastre. Desrazão. Comunidade. Testemunho. Literatura Brasileira. 
LUBLINER, C. M. Fragment, Writing of Disaster and Testimonies of Unreason. 2016. 122 f. Dissertação (Mestrado) - Faculdade de Filosofia, Letras e Ciências Humanas, Universidade de São Paulo, 2016.

\begin{abstract}
This research aims to put in dialogue, in a mutual movement of enlightenment, the concepts exposed in the book L'Écriture du Désastre of Maurice Blanchot and the production of a group of Brazilian writers, gathered here in the form of a so-called "community of unreason". We will initially depart from Blanchot' stimuli to the practice of fragmentary writing that will later appear in the writing of disaster. These references are based, above all, in the thoughts of two German philosophers: F. Schlegel and F. Nietzsche. After visiting the fragment in writing we will go directly to the lifting of a kind of "alchemical composition" there seems to be in Blanchot's disaster. This will be done by the identification of some concepts that surrounds it, in the formation of a body, molecularization and substantiation of the disaster. As an example of this "bodyfication" we will use Alain Resnais' Hiroshima mon amour, work that exposes a cleft in the 20th century through the nuclear barbarism. We will gather then, through the concept of community, raised by French philosopher Jean-Luc Nancy, authors of Brazilian literature that produced writings from folly states. Part of their testimonies where even written during and after periods of psychiatric hospitalizations. This authors are: Lima Barreto, Maura Lopes Cançado, Torquato Neto, Renato Pompeu and Rodrigo de Souza Leão. Due to the confessional charge that many of these texts present, we will use the thought about testimony - that speculates the relation between fiction and reality - proposed by Jacques Derrida. We will also seek to glimpse how the disaster alchemy's elements hover and operate in these writings. Finally, we will present the poetic-audiovisual work created by us: Fukushima mon amour, displaying the differences and transmutations of time through the mediation of the disaster and the unreason in art produced again from nuclear accidents.
\end{abstract}

Keywords: Writing of Disaster. Unreason. Comunity. Testimony. Brazilian literature. 


\section{SUMÁRIO}

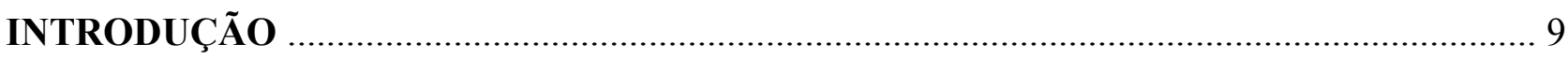

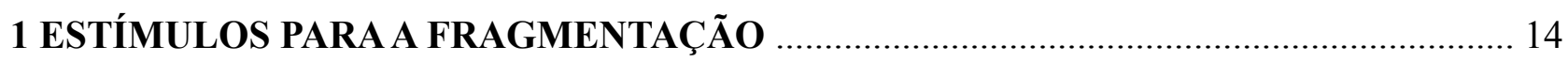

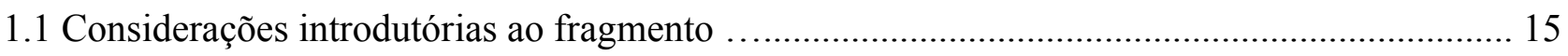

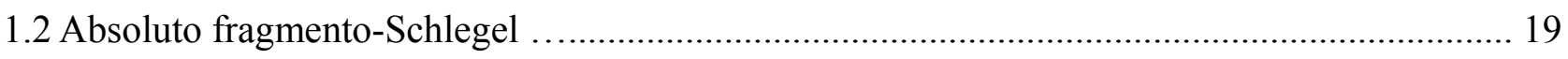

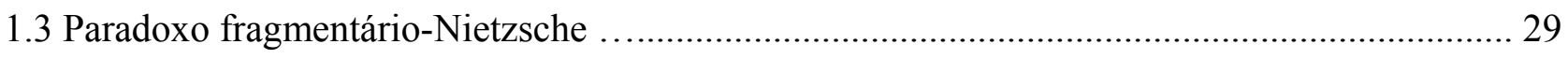

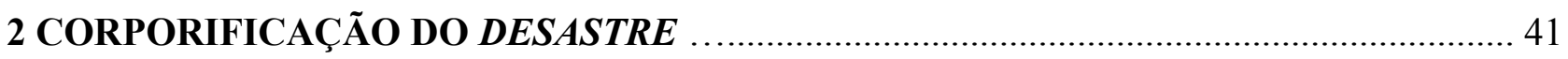

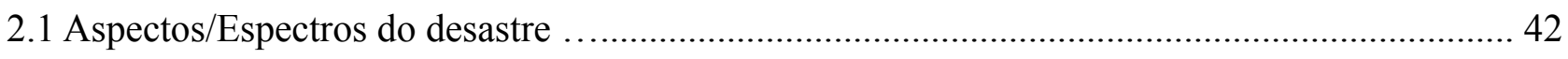

$2.2 \mathrm{O}$ desastre como substância alquímica: elementos de composição ............................................. 51

2.3 Três cenas primitivas a partir de Hiroshima mon amour .......................................................... 67

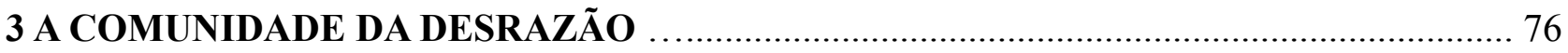

3.1 Diluindo a história: sobre crises e comunidades ................................................................... 77

3.2 Loucura e desrazão: desvio e distinção …………………………………………….......... 84

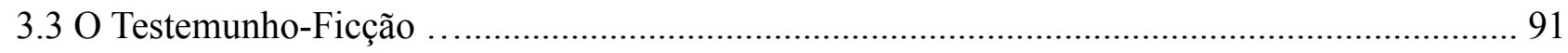

3.4 Uma língua-outra: todog ........................................................................................ 104

4/CONCLUSÃO FUKUSHIMA MON AMOUR: UM UPGRADE ATÔMICO …………….... 109

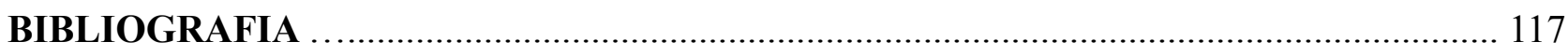




\title{
INTRODUÇÃO
}

\begin{abstract}
"O tempo todo me vi às voltas com palavras inadequadas, séries associativas viciadas, cadeias lógicas incontornáveis, armadilhas metafísicas, enfim, me espreitando nos interstícios mais inesperados da escrita. Tudo se passa como se a linguagem resistisse em liberar uma incerteza."
\end{abstract}

Peter Pál Pelbart

Este trabalho de pesquisa busca verificar como um pensamento múltiplo, de vieses os mais variados: literários, filosóficos, políticos, críticos, históricos, artísticos etc., que pode ser associado a aspectos do transcorrer das décadas do século XX até a chegada ao contemporâneo - dizendo bastante dos momentos e sintomas das épocas -, pode iluminar e ser iluminado por uma dada poética da desrazão em língua portuguesa, através da intermediação de alguns conceitos que nos serão bastante caros.

Nosso ponto de apoio principal orbitará as palavras do pensador francês Maurice Blanchot (1907-2003). Lidar com este autor é selar uma espécie de acordo tácito com um estranhamento premente e permanente. Tido - é comum escutarmos falas nesta direção - como filósofo e/ou escritor de difícil compreensão, hermético, Blanchot parece não ter feito qualquer questão de atentar para o perigo e a fraqueza destas adjetivações. Em nossa percepção, estas afirmações ocorrem principalmente pelo pensador francês desconcertar locais de sacramento e certeza na tradição filosófica e literária eurocêntrica. Seus escritos manejam e valorizam aspectos que causam efeitos de aversão no que diz respeito ao discurso em sua plena efetivação e na própria ideia da representação, da transmissão direta de um significado. O paradoxo, a incerteza, o enigma e a aporia são instâncias nas quais buscam transitar seus conceitos. Um dos intuitos deste estudo será portanto o de compor novas leituras para seu pensamento, na tentativa de escapar de supostos clichês que rondam as noções blanchotianas.

Talvez outra fonte de repelimento ao trabalho de Blanchot resida no fato dele ser um escritor de difícil classificação. Tanto as definições possíveis para seus livros (filosofia? Literatura? Romance? Crítica?) quanto sua própria nomeação (filósofo? Romancista? Crítico?) já incidem sobre uma extensa lista de indagações e indefinições. Esta constatação aproxima bastante seu pensamento do que ele próprio parecia pretender alcançar, na medida em que escapa do domínio classificatório e embaça vontades nomeadoras e fixadoras (rumo já a um neutro impessoal do qual falaremos adiante). Um simples exercício ilustra tais afirmações: a visitação a livrarias, bibliotecas ou sebos afim de encontrar suas obras. Nota-se que um mesmo livro de sua autoria pode se localizar nas mais diversas áreas do conhecimento: filosofia, literatura francesa, crítica de arte, teoria 
literária, psicologia...

$\mathrm{Na}$ esteira disto tudo, é possível saber tão pouco da biografia de Maurice Blanchot (até nisto ele pareceu fazer questão de se empenhar - desforçadamente - para conseguir advir seu pensamento, na intenção de dissolver a figura do autor, do que é pertencente ao caráter pessoal) que apenas nos resta nos direcionar ao que para ele deveria ser realmente importante: a escrita e seus conceitos. Ele não ministrou aulas, cursos ou palestras, nem tampouco deu entrevistas, mesmo a sua imagem é quase anônima, opaca, se resumindo a algumas poucas fotografias da época de sua juventude, como se ele mesmo tivesse conseguido apagar sua imagem, paulatinamente. Se não perfeito, poderíamos dizer que este movimento de desaparecimento da figura pessoal do autor foi de alguma maneira exitoso em suas intenções despretensiosas. Neste apagar do sujeito, ele passa a ser remontado e referido unicamente através de seu trabalho. Este caráter está próximo do que disse certa vez o cineasta Jean-Luc Godard (apud DUBOIS, 2004, p.287) quanto a sua pessoa: "eu existo mais enquanto imagem do que enquanto ser real, pois minha única vida consiste em produzi-las". É dentro desta lógica da relação de simbiose entre vida e obra que o filósofo e professor Christophe Bident escreveu uma (e até hoje única) espécie de biografia de Blanchot, não dizendo de sua vida íntima ou contando detalhes pessoais, mas sim visitando cada um de seus livros.

Só nos resta então - para nós que pretendemos, tímida e discretamente, mergulhar em seu trabalho - nos debruçar em suas publicações, nos livros, artigos e ensaios publicados em periódicos e revistas literárias, pois para ele deveria ser apenas isto o que importava. Sua presença é percebida por murmúrios, em ruínas textuais deixadas no espaço. O embaçamento de si, de sua pessoalidade, foi tão grande que, quando ele enfim veio a falecer - já dotado de 95 anos de vida - este desaparecimento, este sumiço físico, material, pareceu nunca ter tido lugar, posto que talvez já ocorrido. Como disse o filósofo Jacques Derrida em um texto escrito na época da morte de Blanchot, ele pareceu ter desaparecido sem morrer, ou morrido sem desaparecer.

O percurso de nosso estudo será composto por três pontos de atravessamento, divididos como capítulos. O primeiro deles diz respeito a força que pode residir em uma escrita fragmentária, na operação literária e/ou filosófica através do uso do fragmento, de breves blocos textuais. Esta prática da escrita bastante valorizada por Blanchot é proveniente, em nossa visão, do estímulo surgido principalmente do pensamento de dois filósofos alemães: Friedrich Schlegel e Friedrich Nietzsche. Elencaremos, portanto, pontos em cada um desses dois autores, ou nos dois, mesmo que aparecendo já de formas diferentes, que parecem caros ao pensador francês, aspectos que ele evidencia para levar suas próprias produções a um local de pertencimento da escrita, no levantamento das potencialidades do fragmento que culminarão como parte integrante e essencial de uma escrita do desastre. 
O segundo ponto de passagem será o trabalho com o livro L'Écriture du Désastre escrito por Maurice Blanchot e publicado no ano de 1980. Observamos nesta obra um dos momentos mais fortes desta produção de uma escrita que se aproxima de forma bastante fiel das condições impostas pelos acontecimentos no e do mundo, na formação de consonâncias e dissonâncias com eventos passados, presentes e futuros da história, até a própria ultrapassagem de seus limites. Neste livro, o pensador francês inscreve através de um fazer particionado - na forma de uma dinamitação do discurso - uma série de conceitos com os quais já vinha trabalhando, esboçando assim um amálgama, uma constelação conceitual. Tendo como perspectiva uma leitura sintomatológica e genealógica - tal qual realizada por Nietzsche -, e depois arqueológica tal qual definida por Michel Foucault, vemos o desastre blanchotiano como fonte de uma escrita que aponta para um intenso poder de heterogeneidade e simbiose (resultante de ditas hibridizações) em diversas ordens.

Sem a intenção de gerar deciframentos para as questões colocadas por Blanchot, buscaremos, seguindo sua própria sugestão, dar corpo a este desastre, ao invés de sentido. Realizaremos assim processos de extração do que identificamos como substâncias componentes deste desastre, partindo da ideia de uma composição alquímica de suas forças elementares.

Um momento-chave para uma grande ruptura ocorrida na história, e bastante presente no pensamento de Blanchot, foi certamente os eventos da segunda guerra mundial, nas atrocidades ocorridas em Auschwitz e no ataque nuclear realizado no crepúsculo daqueles tempos. Optamos por trabalhar então com uma obra artística, no caso cinematográfica, que exibisse, além dos efeitos destes incidentes de proporções mundiais, a operação dos elementos componentes do desastre blanchotiano. Traremos o filme Hiroshima mon amour do diretor Alain Resnais para a proximidade de um corpo do desastre, como definidor de uma transição de época - uma imensa rachadura no século XX - e o apontar para mudanças de paradigmas que ocorreram nos mais diversos campos do saber. Veremos como L'Écriture du Désastre, sendo ainda assombrado por estes acontecimentos, apontou para novos devires, na forma de pressentimentos e injunções dos tempos.

O início do terceiro ponto de passagem consta da breve tentativa de compreensão de como se deram estas mudanças, por meio de tremores que desestabilizaram, diluíram e alteram as diversas formatações existentes no mundo em termos políticos, históricos e artísticos (e a escrita aqui continuará a ser personagem protagonista). Por meio do conceito de comunidade, desenvolvido e operado por um trio de pensadores: Jean-Luc Nancy, o próprio Maurice Blanchot, e posteriormente por Giorgio Agamben, visualizamos - além da reunião de autores que já colocáramos em diálogo, como Schlegel e Nietzsche -, a possibilidade de trabalhar uma poética em língua portuguesa que parece em sintonia com a valorização de uma escrita fragmentária e portadora da potência de elementos do desastre (e como veremos a comunidade é como que composta por seres que levam 
adiante e jogam com conceitos dialógicos). Este grupo de escritores serão reunidos por nós no que chamaremos de uma comunidade da desrazão. Seu agrupamento se dará de forma linear em uma cronologia que perpassa o século XX até a chegada ao século XXI, mas que não infrinja em uma necessária organização temporal fechada. Este método será simplesmente adotado com o intuito de facilitar e dar alguma forma às análises. Estes escritores, nascidos no Brasil, serão: Lima Barreto, Maura Lopes Cançado, Torquato Neto, Renato Pompeu e Rodrigo de Souza Leão. Todos estes autores foram praticantes de uma escrita da desrazão - tendo sido diagnosticados em algum momento de suas vidas como sofredores de crises de delírio e desatino -, produzindo textos frutos de internações em hospitais psiquiátricos. A partir de seus livros serão levantados aspectos da criação de desobras (no sentido do desobramento ${ }^{I}$ proposto por Blanchot e outros autores) sempre fragmentárias e dispersas, dotadas de aproximações da condição da loucura e da desrazão com o desastre e seus elementos. Porém, antes de irmos diretamente a esses escritos da desrazão em língua portuguesa, achamos necessário revisitar uma distinção bastante pertinente quando do trabalho com textos surgidos de cantos literários delirantes e deturpadores do real: a diferença que há entre a loucura e a desrazão. Neste momento faremos referência, sobretudo, ao trabalho bastante profícuo do filósofo Peter Pál Pelbart no que tange o tema.

Indo ainda em rota de colisão com a perspectiva dos autores brasileiros escolhidos, buscaremos pensar como seus escritos passam pelo plano do ato testemunhal, pois quando não contam diretamente de experiências vividas em internações, servem de matéria causal para possíveis ocasiões como estas. É aí que se apresenta como seminal o ensaio Morada, realizado por Jacques Derrida a partir de um pequeno relato testemunhal de Blanchot. Este texto nos será fonte para o entendimento da maneira como o testemunho opera - na costura entre ficção e realidade -, além de suscitar e levantar especulações sobre as semelhanças e as distinções entre os trabalhos dos escritores brasileiros aqui destacados.

Ainda no terceiro capítulo passaremos pela análise da invenção de uma língua, ou idiomaoutro, por Rodrigo de Souza Leão em Todos os Cachorros são Azuis. Afirmaremos a importância desta criação na medida em que ela lida de maneira bastante peculiar com o desnorteamento do que talvez seja a força maior da comunicação entre os seres - os códigos linguísticos. Veremos como isto conferirá um desobramento comunicacional fruto da desrazão balizada por elementos do desastre.

Apesar de ser perceptível a movimentação em uma ordem cronológica e linear da história, nos resguardamos o direito de realizar digressões e trocas temporais no transcorrer do texto, na medida em que pensamos oportunos tais movimentos. Sendo, de acordo com nossas leituras, a

\footnotetext{
${ }^{1}$ Este termo foi traduzido no português, em algumas ocasiões, por inoperância. Na dúvida da pertinência da tradução optamos pela referência direta ao francês desouvrement, mesmo que incorrendo em um neologismo.
} 
pesquisa um trabalho orgânico, um corpo vivo que - apesar de tentarmos a todo instante, principalmente em estágios prévios e resumidos do projeto, delimitar seus contornos, suas fronteiras - não só atende ao chamado do pesquisador, mas também em uma direção inversa quando o próprio pesquisador atende aos chamados da pesquisa, nos debruçaremos sobre as leituras que havíamos encontrado de maneira previa a escrita do texto, da mesma forma que em obras que nos encontraram durante o trajeto do trabalho. Foi necessário, portanto, respeitar a mobilidade inerente a um estudo e as trilhas que acabam por serem abertas, podendo incidir em recuos, avanços, paralisações e etc. Visaremos ainda argumentar sem uma vontade de verdade inexorável, deixando aberturas para a dúvida e o enigma no texto. Buscaremos assim uma aproximação da própria matéria escritural na qual nos apoiaremos, na esteira dos autores aqui estudados, mas respeitando a seriedade e a exigência necessárias em um trabalho acadêmico.

Como forma de interrupção, mas não total fechamento para esta pesquisa, construiremos um capítulo final considerado também como conclusão, no qual retomamos a ideia do desastre nuclear como marcador de fissuras e expoente de uma época, na medida em que aponta para novos paradigmas vigentes. A partir dos acidentes ocasionados na usina nuclear da cidade de Fukushima, em 2011, produzimos e apresentamos uma leitura poético-audiovisual intitulada Fukushima mon amour, que atravessa as noções de uma escrita e corporificação do desastre, bem como de uma escrita da desrazão e do delírio (portadoras das forças fragmentária e testemunhal). A transcrição do texto desta apresentação bem como a veiculação de seu produto audiovisual em um endereço na internet encerrarão por hora este trabalho. 


$$
\begin{aligned}
& 6 \\
& 5 \\
& 5
\end{aligned}
$$

1

\section{Primeiro Capítulo \\ [ Estímulos para a Fragmentação ]}

$$
\begin{aligned}
& 4^{6} 6 \\
& 4
\end{aligned}
$$




\section{$\underline{1.1}$ Considerações introdutórias ao fragmento}

“'Pourquoi des fragments?' me reprochait ce jeune philosophe. - 'Par paresse, par frivolité, par dégoût, mais aussi pour
d'autres raisons...' - Et comme je n'en trouvais aucune, je me lançai dans des explications prolixes qui lui parurent
sérieuses et qui finirent par le convaincre.”

Paul Cioran

De início se coloca como pertinente a realização de algumas considerações no que tange o fragmento, e de que maneira este será abordado nesta pesquisa. Não cabe aqui a aspiração de realizar uma espécie de cartografia completa do fragmento e da escrita fragmentária, nem tampouco a composição de uma historiografia de sua gênese e desenvolvimento, até porque isto já foi concretizado por alguns teóricos, principalmente na França ${ }^{2}$. Não se pretende, portanto, produzir uma forma de catalogação, o que confere uma escolha pela ausência de uma vontade definidora ou definitiva. $\mathrm{O}$ que subsistirá neste trabalho será tão somente uma verificação de como funciona e opera este modo de escrita a partir de um recorte específico.

As referências de Maurice Blanchot para a utilização desta escrita particionada - e como será percebido no transcorrer deste trabalho a questão da escolha, ética e estética, da escrita através de fragmentos será bastante relevante - passará por vários autores e pensadores, tais como: Heráclito, Friedrich Schlegel, Nietzsche, René Char, e outros. Durante as décadas em que publicou ensaios e artigos em periódicos e revistas, Blanchot eventualmente abordou a questão do fragmento nos autores acima citados. Realizaremos aqui um recorte em F. Schlegel e Nietzsche na medida em que entendemos serem estes as fontes principais de estímulo para o pensador francês. Parece-nos que Blanchot traça uma linha, um trajeto do fragmento "Schlegel - Nietzsche" através de temas que atravessam os pensamentos destes filósofos quanto à escrita, e na forma em que a praticam, mesmo que de formas diferentes: o inacabamento, a polifonia filosófica, a descontinuidade, o paradoxo e a busca pela diferença.

Observa-se como é no que lhe falta que o fragmento encontra boa parte de sua força, se retirando das garantias e exigências firmadas e categorizadas por toda tradição do pensamento e da escrita eurocêntrica. O pensador francês pareceu encontrar em F. Schlegel e Nietzsche aliados para construir seu pensamento quanto ao ato de escrever, e o caráter fragmentário terá participaçãochave para a concepção de uma escrita do desastre, tal qual trabalhada adiante neste estudo. O fragmento se consolidará em Blanchot como um caminho para o embaralhamento de gêneros, em um grande desvio estilístico, que culminará exatamente no que ele concebe como desastre, e na

\footnotetext{
${ }^{2}$ Utilizaremos inclusive o trabalho de alguns deles, como nos casos de Pierre Garrigues, Philippe Lacoue-Labarthe e Jean-Luc Nancy.
} 
tentativa e experiência de sua prática.

Apoiaremos-nos principalmente em dois ensaios de Blanchot, originalmente publicados na Nouvelle Revue Française: "Athenäum", da edição de agosto de 1964, e "Nietzsche e a escrita fragmentária" dividido em duas partes nas edições de dezembro de 1966 e janeiro de $1967^{3}$.

Um aspecto interessante acerca do fragmento é que a sua definição povoa regiões bastante nebulosas. De maneira rasa, poderia se dizer que o fragmento é qualquer parte breve e condensada de texto. Mas qual deve ser o tamanho de um escrito? Ele deve necessariamente possuir uma duração preestabelecida?

A tradição ocidental nos diz que um texto, principalmente de caráter filosófico, deve durar até que tenha esclarecido todas as questões que levanta, e explicado plenamente o que pretendeu expor em linguagem (sendo esta mediada e regida a todo instante pelo entendimento e significação). No final das contas, tanto as filosofias (a produção de um método ou sistema esclarecedor) quanto as literaturas (a narrativa perfeitamente amarrada) ditas clássicas ou convencionais buscam a todo custo o sentido, os significados que levam diretamente ao entendimento - tudo deve ser coerente e compreensível, e caso isto não ocorra o texto é dado como fracassado, na medida em que não encontra nenhuma revelação direta e exata, despejando dúvidas e incertezas pelo caminho. São por outras vias que caminharão F. Schlegel, Nietzsche e Blanchot, que exploram novas potencialidades de alcance do pensamento e da escrita, inclusive, e talvez principalmente, mediante a incorporação do que pela tradição seria tido como erro, imprecisão.

Uma das maiores dificuldades talvez se encontre na perspectiva de que a teoria do fragmento se dá apenas diretamente em sua prática, acabando mesmo por fundir estas duas ideias, dissolvendo a separação que há entre elas - a teoria se torna sua prática e vice-versa. Isto se encontra principalmente em F. Schlegel, que apesar de apostar na escrita filosófica por meio de fragmentos, nunca chegou exatamente a teorizar a respeito dessa escolha ${ }^{4}$. As poucas pistas para sua compreensão estão nas características principais que carrega consigo, a saber:

(...) o relativo inacabamento ("ensaio") ou a ausência de desenvolvimento discursivo ("pensamento") de cada uma de suas peças; a variedade e a mistura dos objetos de que pode tratar um mesmo conjunto de peças; a unidade do conjunto, ao contrário, como constituída de alguma maneira fora da obra, no sujeito que se dá a ver ou no julgamento que ele entrega em suas máximas. (LACOUE-LABARTHE e NANCY, 1978, p.58, tradução nossa)

Este trecho já especula algumas questões próprias à escrita fragmentária, como, por exemplo,

\footnotetext{
${ }^{3}$ Faremos uso das traduções realizadas por João Moura Jr. destes ensaios, incluídas nas edições brasileiras em $A$ Conversa Infinita 3 - A Ausência de Obra e A Conversa Infinita 2 - A Experiência limite, respectivamente.

${ }^{4}$ Restringindo-se a poucos trechos nos quais apenas louvava o ato da escrita fragmentária.
} 
a de um discurso que não busca incessantemente a coerência e a lógica total do texto, afastando-o assim daquele praticado até então - vale lembrar que F. Schlegel produziu a maioria de seus fragmentos durante o final do século XVIII e o início do XIX. O fragmentário busca implodir o discurso através da descontinuidade e do inacabamento, características díspares daquelas que são às da essência da discursividade: o sentido e a coesão, uma ideia colocada em pauta, destrinchada e extremamente bem explicada. Outra questão pertinente se localiza na produção de uma primeira abertura própria ao fragmento: ele não busca tudo amarrar ou completar, dando espaço para este "fora da obra", como em uma entrega de peças para a composição de um quebra-cabeça, as quais o leitor pode manejar e encaixar como bem quiser, formando diversas paisagens possíveis de recepção. O que busca então a escrita do fragmento? Tudo indica que os espaços relegados na escrita convencional - escravizada pelo discurso -, e a atuação em fatores antes tidos como fraquezas de um texto, construindo assim entradas para novas formas de expressividade, ou seja, não mais a pura expressão, a intenção de "expressar algo".

Ainda não se trata, em F. Schlegel e no romantismo, de gerar rupturas drásticas com aspectos do humano, como por exemplo com a noção pura de autoria (algo que veremos se principiar em Nietzsche e ganhar contornos intensos de uma impessoalidade em Blanchot), mas simplesmente um explorar de outras fontes. Pierre Garrigues afirma (1995, p.19, tradução nossa): "A escrita do fragmento: violência que o homem inflige contra si mesmo, para encontrar... o silêncio, o grito, a aliança maravilhosa da língua e de algo que ele nunca espera, o eternamente residual...”. Bela imagem esta da coleta de um resíduo, processo de depuração do pensamento para o texto. Trata-se ainda de confrontar tanto a forma quanto o sentido textual, para que nenhum dos dois imponha sua lógica e retórica (GARRIGUES, 1995, p.385).

O fragmentário habita a desordem, o caos e a contradição, mas sem fugir de uma postura organizacional: ordena casualmente. Suas ditas imperfeições são os seus bens mais preciosos; são por vias comumente pensadas como erráticas que os fragmentos se fundam e se desenvolvem. Neles, os pensamentos são compostos de maneira a se desfazerem, se desmembrarem permeados que são por interrupções abruptas. O que pertence à ordem do involuntário e do acidental interessa certamente ao fragmentário (LACOUE-LABARTHE e NANCY, 1978, p.60), já que em nome do inacabamento e da brevidade de sua composição uma série de proposições e colocações que poderiam ser talvez ainda mais destrinchadas são deixadas à deriva, na formação de portos móveis e itinerantes abertos aos deslocamentos das leituras que podem suscitar. Cada bloco textual se configura assim como uma parte, uma porção acerca de um tema ou pensamento em constante quebra, e o que deles resta são desdobramentos metonímicos de uma reflexão.

A composição de fragmentos realiza ainda dentro da escrita, e consequentemente da 
filosofia, aberturas para várias possibilidades anteriormente relegadas ou mesmo impensadas. O que está fora da obra é tão importante quanto o que ela contém, sua pluralidade reside também no fato de não ignorar ou repudiar o que pode não estar totalmente esclarecido ou definido nela. É garantido desta maneira um dinamismo oculto entre o que está no texto e o que não se encontra diretamente nele, expresso em linguagem. Há também a valorização de um “dizer pouco”, que não trata de uma pobreza ou fraqueza de pensamento, mas sim de uma riqueza que pode estar contida na brevidade - rápida passagem, porém não menos intensa.

Uma imagem sedutora aferida aos fragmentos é aquela que os toma por uma constelação, como se cada bloco fragmentário ocupasse uma posição estrelar, em forma de microcosmos poético-filosóficos. Em cada uma dessas pequenas estrelas ocorrem breves instantes de convergência entre o tempo presente e a eternidade. Para F. Schlegel, a brevidade do fragmento busca tocar esta eternidade, em um tempo efêmero que, no entanto, pretende congelar ou cristalizar um pedaço do eterno. É como aponta Garrigues (1995, p.33, tradução nossa): "Não se trata do texto, mas de um lugar cósmico entre a presença do mundo e a brevidade do verbo".

A realidade do fragmento a partir de F. Schlegel se produz por meio de algumas tensões, o que ganhará contornos mais intensos em Nietzsche e Blanchot. O desejo de se afastar da noção de sistema, sem, no entanto, conseguir abandoná-la por completo; a vontade de ir além do discurso na escrita fazendo uso todavia da própria linguagem. O fragmentário trabalha ainda aos poucos, mas em movimentações que alternam velocidades, entre o slow motion e o fast forward, sendo este ritmo revelado por detrás da intensa quebra e contínua interrupção do texto: “Assim somos levados a conceber a escrita como um devenir de interrupção, o intervalo móvel que se designa talvez a partir do interdito, mas abrindo-o para nele pôr a descoberto não a Lei, mas o entredizer ou o vazio da descontinuidade" (BLANCHOT, 2007, p.268). Um outro trecho de Blanchot (2010, p.41) expõe a força das rupturas fragmentárias:

Fala de fragmento: é difícil aproximar-se dessa palavra. "Fragmento", um substantivo, mas com a força de um verbo, no entanto ausente: fratura, frações sem restos, a interrupção como fala quando a interrupção da intermitência não interrompe o devir mas, ao contrário, o provoca na ruptura que lhe pertence.

\section{$\underline{1.2}$ Absoluto fragmento-Schlegel}

"Na tempestade o ar se fecunda."

Friedrich Schlegel 
No inicio do século XIX a Europa vivia um momento particular de turbulência nos âmbitos político e social com a explosão da revolução francesa e as subsequentes invasões napoleônicas que se disseminaram por todo o território europeu. No campo das artes e da filosofia esse sentimento de tensão se caracterizava por constantes mudanças de rumos estéticos e por invenções de novos pensamentos. A Alemanha, por exemplo, vivia um período de intensa fertilidade e comoção a partir de todo o pensamento elaborado por dois personagens capitais na história da filosofia e da literatura: Immanuel Kant e Johan Wolfgang von Goethe. No entanto, já a partir dos últimos anos do século XVIII, alguns autores da filosofia - denominados inclusive como "pós-kantianos" passaram a divergir de algumas das ideias de Kant, principalmente no que tangia sua vontade de completude formada por um sistema filosófico puramente crítico-racional. Foi então a partir dessa perspectiva, em um movimento de desvio do chamado "idealismo alemão", que se encontraram os autores tidos como "os primeiros românticos" ou A Escola de Iena 5 .

As inquietações dos autores "pós-kantianos" se encontravam, em um primeiro momento, na ausência do próprio princípio sistematizador em Kant, pois apesar de ter passado por ditas "formas singulares", o filósofo de Koenisberg não explicitou qual seria a conexão necessária destas com uma dada forma originária - uma totalidade, unidade maior - da filosofia. É neste ponto que um pensamento filosófico pendente à fragmentação tem lugar. F. Schlegel conclui que para buscar a totalidade (vemos neste momento como ele e seus contemporâneos ainda estavam próximos a Kant) é necessário que o discurso, e mesmo o sistema, seja dilacerado, entregue ao caos, quebrado em pequenos pedaços, fragmentos, para quem sabe, a posteriori, chegar a uma condição de conjunto, de unidade. Diz Márcio Suzuki na apresentação a uma das obras de F. Schlegel (1997, p.12):

Em vez de sintoma de um fracasso intelectual, a percepção da fragmentação e do dilaceramento da consciência poderia ser antes considerada como um dos instantes em que o idealismo alemão se dá conta de seus limites, em que passa a investigar seus próprios pressupostos e a corrigir seus desvios (...) O caso de Schlegel é tanto mais interessante, porque desde o início já se mostra reticente quanto ao ideal de sistematicidade pelo qual a filosofia pretende adquirir foros de ciência (...) [Schlegel busca então] despir a filosofia de seu aparato artificial, tecnicista, tentando torná-la tanto quanto possível apta a expor o saber na figura original em que ele mesmo imediatamente se manifesta.

O fragmento em F. Schlegel surge portanto como opção para a tentativa de solucionar um problema de natureza filosófica, aproximando talvez a filosofia de uma ideia literária, do pensar mesmo da escrita, na construção de um gênero - o que animou Jean-Luc Nancy e Philippe LacoueLabarthe a identificarem os autores de Iena como definidores de um absoluto literário - e buscando

\footnotetext{
${ }^{5}$ Grupo formado pelos irmãos Schlegel (Friedrich e August Wilhelm), suas respectivas esposas na época Dorothea e Caroline, além de Novalis, Schleiermacher, Tieck e Schelling.
} 
retirá-la de um âmbito muito técnico/científico, no qual a filosofia kantiana a colocara. Este desvio para uma noção mais próxima da literatura tinha por intuito justamente possibilitar uma composição com a ideia de gênero, além de diminuir a carga muito cientificista para o qual se encaminhou a filosofia, sem, no entanto, se livrar da vontade de construção de uma Obra, portadora de uma totalidade.

O pensamento sobre uma "forma do filosofar" é objeto crucial para F. Schlegel e o grupo de Iena. Esta afirmação coloca em pauta o problema acerca de um certo estilo. Mesmo que neste ponto se aproximando da literatura (no que apenas os filósofos mais radicais e tradicionalistas veem como demérito), praticando a ideia de que "a filosofia deve se efetuar - se cumprir, se alcançar e se realizar - como poesia” (LACOUE-LABARTHE e NANCY, 1978, p.51, tradução nossa), na confecção de um novo tipo de obra em vista (pois esta noção ainda estava plenamente em voga na época), é inegável que a escola de Iena praticou filosofia:

(...) com efeito o romantismo, se não é ele mesmo inteiramente nem simplesmente filosófico, só é compreensível (dito acessível) em todo rigor a partir do filosófico, na sua articulação própria e de resto única (ou seja inédita) ao filosófico (LACOUE-LABARTHE e NANCY, 1978, p.42, tradução nossa).

Tendo estas preocupações, e com a vontade de construir um veículo próprio para trabalhar a filosofia, foi criada pelos irmãos Schlegel a revista Athenäum, publicada em seis volumes entre os anos de 1798 e 1800. Esta publicação se tornou o meio catalisador das proposições dos primeiros românticos alemães, e local onde Friedrich Schlegel, maior incentivador da prática fragmentária, pôde expor, além da sua ideia de valorização deste fazer filosófico, a expressão do pensamento através de uma escrita particionada. No entanto, a forma de escrita na qual F. Schlegel primeiro observou a possibilidade da exposição do fragmento foi através dos diálogos - em uma prática ainda embrionária de suas possibilidades.

O desejo de construção de uma comunidade filosófica pelos membros da escola de Iena foi um marco importante na busca por uma escrita plural, coletiva, no sentido de envolver e conter várias vozes, como em um canto, na organização de um coral filosófico. Nela, várias subjetividades e estilos se encontravam em linguagem, fala e texto. A meditação e conversa acerca de assuntos os mais variados dentro de uma obra - poesia, estilo, crítica, filosofia, política etc. - constituía um conjunto condensado em livro ${ }^{6}$. Este transitar por temas diversos produzia pensamentos que poderiam ir em direções opostas, somando riqueza crítica ao invés de ser abordado como algo prejudicial, em uma “incessante e autocriadora alternância de pensamentos diferentes e opostos"

\footnotetext{
${ }^{6}$ Apesar de creditados apenas a F. Schlegel, Conversa sobre poesia e Dialeto dos Fragmentos são livros que possuem a participação de outros membros do grupo de Iena.
} 
(apud GARRIGUES, 1995, p.165, tradução nossa), como disse F. Schlegel.

O grupo de Iena apontou, sem, entretanto, efetivar esta noção que ganhará força a partir de Nietzsche, para uma primeira percepção da contradição e da afirmação de uma subjetividade múltipla, além de buscar a quebra do discurso através da suspensão e interrupção abrupta de uma reflexão individual. Foi a partir destes diálogos que F. Schlegel, após o término destas conversas com seus convivas, passou a praticar solitariamente, mas levando em conta estes fatores de multiplicidade, sua escrita fragmentária.

Segundo Márcio Suzuki, para F. Schlegel o pensamento deveria ser "uma forma fragmentária, que, livre da maquinaria técnica, pudesse ser tão orgânica quanto a própria 'vida"' (SCHLEGEL, 1997, p.18). Esta "maquinaria técnica" dizia respeito às formas desenvolvidas anteriormente no decorrer da história da filosofia - aos próprios métodos de escrita, que partiam da enunciação de um único ser, tendo como ocupação e objetivo final a construção de um sistema absoluto e completo. Como vimos, os filósofos de Iena ainda se encontravam atados a busca por um Todo, por algo de Uno na filosofia, mas realizavam isto por meio de uma aproximação com a poesia e a literatura, o que resultava em desvios das convenções anteriormente praticadas. Deste modo, F. Schlegel parece querer resgatar uma espontaneidade perdida no filosofar, tendo em mente que para isso seria necessário como que "poetizar a filosofia" (LACOUE-LABARTHE e NANCY, 1978, p.386, tradução nossa).

A escrita tornada um grande diálogo aberto em que o ato de escrever e filosofar se tornaria conjunto, afastava a visão que ganhara força nos anos e séculos anteriores: a da figura do filósofo como um ser solitário que criaria um sistema, um método próprio para resolver todas as questões do mundo (em um claro continuísmo demiúrgico). Interessante notar que cada um dos integrantes de Iena assumia um pseudônimo, exatamente como um conjunto de personagens, de vozes cambiantes. Este fator aproximava ainda mais o texto filosófico da literatura. Através do diálogo, abre-se a possibilidade de transição e variedade de temas comentados, como ocorreu no caso com a poesia, a mitologia e o romance. Esta característica politemática, e por vezes paradoxal (pois abarcava em alguns momentos, como mencionado, diferentes opiniões e perspectivas), foi incorporada por F. Schlegel no interior da sua escrita fragmentária como veremos adiante. A escrita e a filosofia se tornariam neste caso efetivamente uma conversa, legítima polifonia, para além de monólogos puramente reflexivos. Uma obra composta por autores/atores. A contradição e o paradoxo puderam aparecer então, mesmo que neste momento ainda discretamente, como noção oportuna para o desenvolvimento do fragmento, da justaposição e abertura para a relação entre ideias aparentemente conflitantes - algo que seguirá com força, e com contornos diferenciados, em Nietzsche e mais tarde em Blanchot. 
Tudo leva a crer, portanto, que este tipo de diálogo influenciou intensamente a escolha de F. Schlegel pela escrita fragmentária, mesmo que tendo continuado a mesma ideia, porém de forma solitária - tomando então outro caráter na prática do fragmento. Apesar de ser o maior incentivador e praticante deste modo de escrita, outros integrantes do grupo de Iena participaram da escrita de fragmentos, como nos casos de A. W. Schlegel e Novalis.

Para F. Schlegel, reside no pensamento através de breves blocos a possibilidade de aproximação maior do próprio pensar humano, da maneira mesmo como operam nossas meditações. Conforme escreve Márcio Suzuki: “[para Schlegel] o indivíduo é como que uma parte, um pedaço, fração, fratura ou fragmento de si mesmo" (SCHLEGEL, 1997, p.16). Para o filósofo alemão, desenvolver pensamentos em texto de maneira fragmentária seria uma atitude de fidelidade com a própria condição humana, de sua impossibilidade de se colocar por completo em qualquer pensamento (ou livro, ou texto, ou sistema filosófico, ou poema etc.). Diz Schlegel (ibid., p.25):

Para poder escrever bem sobre um objeto, é preciso já não se interessar por ele; o pensamento que se deve exprimir com lucidez já tem de estar totalmente afastado, já não ocupar propriamente alguém. Enquanto o artista inventa e está entusiasmado, se acha, ao menos para a comunicação, num estado iliberal. Pretenderá dizer tudo, o que é uma falsa tendência de gênios jovens ou um justo preconceito de escrevinhadores velhos. (...) Um autor que quer e pode se abrir por inteiro, que nada retém para si e se compraz em dizer tudo o que sabe, é no entanto deveras lastimável.

A maioria dos textos filosóficos que antecederam a escola de Iena se colocavam sempre como longas e extensas retóricas escritas, que visavam e necessitavam de coesão e acabamento, com a finalidade inexorável da plena compreensão e demanda explicativa. A noção de sistema, muito explorada pela filosofia até então, leva F. Schlegel a constatação de que ter e não ter um sistema poderia ser igualmente perigoso, pois romperia com a maneira própria e singular do pensamento operar. Pelo plano da negação - opção antípoda à maneira tradicional de se produzir filosofia - a simples recusa de um sistema acarretaria em sua continuação, no final das contas em uma opção por um não-sistema. O filósofo de Iena opta por desenvolver suas reflexões através de uma nova maneira de compreensão e atuação filosófica. Blanchot cita um fragmento de Schlegel: “Ter um sistema é, para o espírito, tão mortal quanto não ter: será, pois, preciso que ele se decida a perder tanto uma quanto outra dessas tendências" (apud BLANCHOT, 2010, p.111).

A partir do desejo de ruptura com tais tendências o filósofo alemão decide por um sistema fragmentário, que não exclui uma vontade sistêmica, mas que se diferencia do sistema convencionalmente praticado em filosofia até o início do século XIX (e mesmo de seus contemporâneos, como no caso de Fichte e Schelling, que ainda mais próximos e bastante voltados 
a Kant, compuseram o sistema do idealismo transcendental). Isto passou inevitavelmente por um acolhimento da desordem no filosofar, de uma força especulativa, o que atingiu diretamente e evidentemente a escrita. Fazer da desorganização uma obra seria tarefa deste novo filósofo romântico, praticar uma espécie de organização desorganizada, desgovernada, que aponta para múltiplas vias e temas. Este primeiro desarranjo causado pelo fragmento garantiu uma instabilidade não mais tida como nociva para o texto filosófico. Segundo Blanchot (2010, p.43):

Um arranjo de tipo novo, que não seria o de uma harmonia, de uma concórdia ou de uma conciliação, mas que aceitará a disjunção ou a divergência como o centro infinito a partir do qual, pela fala, uma relação deve estabelecer-se: um arranjo que não compõe, mas justapõe (...)

Além disto, na fala fragmentária ocorrem dissoluções do acabamento, da exposição de uma verdade austera. A noção de unidade da obra passa por uma transformação, sendo esta alcançada (nunca é demais frisar que em F. Schlegel a vontade de totalidade ainda é um objetivo em vista) no conjunto de fragmentos e na individualidade própria a cada um deles. Segundo Lacoue-Labarthe e Nancy (1978, p.64, tradução nossa): “A totalidade fragmentária, conforme aquilo que deve se nomear como a lógica do ouriço, não pode ser situada em nenhum ponto: ele está simultaneamente no todo e em cada parte". Os fragmentos pretendem evidenciar o singular dentro de uma totalidade, assim como o total na singularidade própria a cada um dos blocos textuais.

O tema organizacional dá a ver também a questão da continuidade, em virtude das constantes interrupções de fragmento para fragmento. A reflexão, assim como a leitura, acaba se discorrendo por uma sequência descontínua promovida por movimentos de entrelaçamento intervalados por bruscas interrupções. Este tipo particular de passagem acontece na forma de um desmantelar do discurso, sendo as falas sobre um mesmo tema retomadas em diferentes pontos da obra, sem uma linearidade demarcada. Cada fragmento pode ser identificado como um porto temático, levado pelo autor a destinos provisórios e dirigido a focos de interesse específicos. Sobre o caso da necessidade de coesão e acabamento na escrita, F. Schlegel escreve na revista Lyceum, fragmento $\S 33$ :

Uma das duas é quase sempre inclinação dominante de todo escritor: ou não dizer muito daquilo que teria absolutamente de ser dito; ou dizer muito daquilo que não precisava ser dito de modo algum. O primeiro é o pecado original das naturezas sintéticas; o segundo, das analíticas. (SCHLEGEL, 1997, p.24)

Em defesa de sua tese fragmentária, afirma mais a frente, no fragmento $§ 103$ : 
Muitas obras apreciadas pelo belo encadeamento têm menos unidade que uma diversificada porção de achados que, animados apenas pelo espírito de um espírito, apontam para uma meta única. (...) Em contrapartida, alguns produtos, de cuja coesão ninguém duvida, não são, como bem sabe o próprio artista, uma obra, mas apenas um ou muitos trechos, massa, disposição. $\mathrm{O}$ impulso é, porém, tão poderoso no homem, que frequentemente, já durante a composição, o próprio criador complementa ao menos aquilo que não pode absolutamente perfazer ou unificar; e frequentemente o faz com grande riqueza de sentido, mas de modo inteiramente antinatural. $\mathrm{O}$ pior nesse caso é que tudo aquilo que, para dar uma aparência de totalidade, se agrega às partes sólidas efetivamente existentes geralmente não passa de remendos coloridos. (ibid., p.35-36)

Este exemplo demonstra o jogo de digressões e retomadas para os quais pretendem apontar os fragmentos, esta continuidade descontínua que parece unificar as falas, sem, no entanto, perder seu caráter de interrupção. Um tom paradoxal também se faz presente na medida em que F. Schlegel admite a necessidade de uma completude ao fragmento, devendo este se bastar em si, na mesma medida em que valoriza um inacabamento inerente à quebra abrupta de um pensamento. No final das contas o fragmentário para o filósofo alemão não se priva evidentemente de certo rigor, mas que é transtornado principalmente em prol de uma nova forma de reflexão escrita embaralhada, em ruína.

O que chama mais a atenção neste movimento proposto por F. Schlegel é a noção - em consonância com o momento e um dado espírito histórico - de que havia uma crise velada na filosofia, que demandava a necessidade da construção de um outro caminho para o pensamento e a escrita. Este desvio, deslocamento da prática filosófica, acarretava na abdicação da busca por um controle das faculdades do pensamento traduzidas em texto. Uma vontade da diferença, e até mais do que isso, uma exigência, ainda que discreta e atada aos recentes desdobramentos da filosofia na época, se colocava na concepção de uma obra. Maurice Blanchot descreve os caminhos do pensamento de F. Schlegel e dos primeiros românticos alemães:

Decide-se considerar certos traços como de pouco importância, e outros como os únicos autênticos: como acidental o gosto pela religião, como essencial o desejo de revolta; como episódica a preocupação com o passado, como determinante a recusa da tradição, o apelo ao novo, a consciência de ser moderno; como um traço momentâneo as inclinações nacionalistas, como um traço decisivo a pura subjetividade que não tem pátria. $\mathrm{E}$ se, finalmente, todos esses traços juntos são reconhecidos como igualmente necessários, por serem opostos uns aos outros o que se torna o tom dominante não é o sentido ideológico de cada um deles tomado isoladamente, mas sim sua oposição, a necessidade de contradizer-se, a cisão, o fato de estar dividido - aquilo que Brentano chama die Geteiltheit -, e o romantismo, caracterizado como a exigência ou a experiência das contradições, só faz confirmar sua vocação para a desordem, ameaça para alguns, promessa para outros e, para outros ainda, ameaça impotente, promessa estéril. (BLANCHOT, 
O fragmento será ainda o lugar onde a poesia (a arte maior, e que se encontra dentro de todas as outras, segundo os primeiros românticos alemães) e a filosofia poderão erigir o seu livre jogo dialógico, baseado em uma troca que dará vazão ao que será nomeado por sinfilosofia, que pode ser definida como uma busca por um caráter universalizante (não só em termos sociais, mas dentro das próprias artes), sendo este conceito inclusive importado para dentro do todo fragmentário. Este modo de filosofia aponta ainda para uma relação fraterna (o que reforça a reunião do grupo em Iena), na produção de uma força criadora pautada na amizade. Um universal orgânico, posto que concentra características que podem dizer respeito a todos. Este pensamento remete evidentemente a Goethe, que foi o primeiro a pensar e perseguir uma weltliteratur ou literatura universal. Novalis afirma categoricamente: "Distinguir o poeta do filósofo é fazer mal a ambos" (apud BLANCHOT, 2010, p.104). Arte e ciência, segundo estes pensadores, deveriam entrar em conjunção, sem imposições hierárquicas, tendo ambas funções específicas e primordiais.

Torna-se então factível afirmar que a Escola de Iena praticou também uma forma de filosofia da arte. Visando uma "integração harmoniosa" entre estes dois campos, os primeiros românticos acreditavam que "o que a filosofia revela abstratamente, a arte realiza, tornando concreta a filosofia" (BORNHEIN, 1959, p.59). Este é um ponto que certamente atraiu Blanchot ao primeiro romantismo, o desejo de colocar em processo de conversação, de relação, filosofia e arte, história e crítica.

(...) pôr uma poesia em contato com filosofia e retórica. Quer e também deve ora mesclar, ora fundir poesia e prosa, genialidade e crítica. (...)

Só alcança a harmonia mediante o vínculo de poesia e filosofia: essa última síntese parece faltar também às obras mais universais e mais perfeitas e acabadas da poesia e da filosofia isoladas; próximas à meta da harmonia permanecem imperfeitas e inacabadas. A vida do espírito universal é uma cadeia ininterrupta de revoluções internas; nele vivem todos os indivíduos, os originais, eternos. É um genuíno politeísta e traz o Olimpo inteiro em si. (SCHLEGEL, 1997, p.64/142)

Este grupo denominado como os primeiros românticos tinha já consciência da vastidão de civilizações, e levava em conta a existência de uma história da arte em outros lugares que não apenas na Europa. Esta ideia do universal, de uma globalidade ainda embrionária para estes autores, está vinculada a uma sensibilidade do humano ligada ao poético, sendo possível sua existência em diversas expressões, mas que acabariam sempre unindo filosofia e poesia - gerando "relações de mestiçagens", nas palavras de Alberto Pucheu (2007, p.167). Esta visão do universal nos dias de hoje soa evidentemente ingênua (portanto romântica), todavia condiz com a tentativa do grupo de 
Iena de elevar a poesia ao maior grau possível de absorção e apreciação.

O final da citação acima transcrita, na referência de F. Schlegel ao politeísmo e ao Olimpo, não é em vão. Os primeiros românticos alemães valorizaram bastante a mitologia grega, e buscaram mesmo a criação de uma espécie de nova mitologia - na esteira do homem racional, surgido após a força de Goethe e de um ideário iluminista. Um trecho de um texto de autoria não-identificada (nada mais próprio a Blanchot do que um tal início, como veremos adiante) expõe parte do pensamento dos primeiros românticos:

(...) nós devemos ter uma nova mitologia, mas essa mitologia deve estar a serviço das Ideias, ela deve se tornar uma mitologia da razão (...) a mitologia deve se transformar em filosofia para tornar o povo razoável, e a filosofia deve se transformar em mitologia para tornar os filósofos sensíveis. (apud LACOUELABARTHE e NANCY, 1978, p.54, tradução nossa)

O fragmento se apresenta para o filósofo romântico como opção necessária, que na verdade não se pode exigir, por vir a priori de forma espontânea. $\mathrm{O}$ entrelaçar entre pensamento e poesia clamam por ele, pois no fragmento a perspectiva humanista da qual ainda partilhava F. Schlegel e os primeiros românticos alemães, sente-se finalmente apta a exercer um livre jogo de escrita filosófica. Pulsa aqui um primeiro, e quase primitivo, caráter fragmentário: a admissão de que o texto é apenas uma pequena fratura do ser. Conforme Garrigues (1995, p.13, tradução nossa):

A prática do fragmento é uma resposta, paradoxal, ao fenômeno da fragmentação: conjuração, exorcismo, mas também paixão (...) ela é uma necessidade humana, como o espírito que abre o homem ao infinito e lhe dá a liberdade de "fluir quando bem quiser, sem solicitações exteriores (Novalis)".

A criação e instauração de um novo gênero de escrita seria, portanto, essencial. Algo que se colocasse para além de um texto puro de filosofia, que abrisse leques para gêneros poéticofilosóficos e críticos. Esta fusão de gêneros pode ser considerada como um primeiro movimento, discreto e provavelmente inconsciente (já que na própria ideia de romantismo temos ainda uma definição classificatória), em direção ao que mais tarde, na exacerbação de alguns dos fatores fragmentários caros a F. Schlegel - e da incorporação e participação de diversos outros elementos, como veremos -, se configurou como uma ausência ou indistinção de gênero, de uma hibridização identificada e trabalhada intensamente por Blanchot. A mera expressão "fragmento" já possui como que uma aura de indefinição, posto que, em um primeiro momento, apenas diria que um escrito é breve e parcial. De acordo com Lacoue-Labarthe e Nancy (1978, p.62, tradução nossa): “se por um lado ele [o fragmento] não é uma pura parte, por outro ele também não é nenhum destes termos- 
gêneros dos quais se serviram os moralistas: pensamento, máxima, sentença, opinião, anedota, observação".

O que parece também animar a todo instante a noção de fragmento praticada pelos românticos será a crítica. Para eles, inclusive, não fazia o menor sentido a separar obra e crítica. No pensamento dos membros da escola de Iena, inúmeros olhares foram lançados sobre o mundo, tanto em termos de estética (provavelmente a maior das ocupações do grupo) como de religião e política (um pouco próximo do que Nietzsche pretendia dizer quando afirmava que os filósofos deveriam ser como "médicos da civilização"), algo que talvez não pudesse ser diferente dadas as intensas e conhecidas mudanças ocorridas no mundo na transição do século XVIII para o XIX. Segundo Gerd Bornhein (1959, p.12): “O romântico seria sempre uma fase de rebelião, de inconformismo aos valores estabelecidos e a consequente busca de uma nova escala de valores (...)”.

O fragmento foi o meio pelo qual F. Schlegel vislumbrou a possibilidade de trabalhar suas reflexões da forma mais condizente com suas concepções, permitindo-lhe estar mais a vontade para inscrever seus pensamentos. Vale lembrar que o fragmentário não se coloca como uma fórmula ou guia de escrita, mas sim, tão somente como um modo no qual o autor (nunca é tarde lembrar que a ideia de sujeito, ser ou gênio romântico estava presente nestes pensadores, algo que tomará outras feições a partir de Nietzsche, chegando até uma espécie de esvaziamento pessoal e autoral em Blanchot) irá se colocar, se expor. Novalis, especificamente, pensava os fragmentos como espécies de sementes filosófico-literárias (daí também o porquê de um livro seu batizado Pólen $^{7}$ ), que só no futuro seriam lidos como deveriam, passando por um processo de germinação - algo que faz novamente referência à participação de fatores externos à obra - através dos tempos.

A interrupção do todo, a descontinuidade de uma retórica pelo fragmento, geradora de lacunas e rupturas, dispara ainda a atuação de um poder rítmico. Mesmo mediante paralisações não há um abandono completo da noção do todo de um escrito, mas sim a garantia de sua perpetuação através de uma multiplicidade, configurando cada fragmento como um conjunto fechado e perfeito em si. Diz Schlegel (1997, p.82) no fragmento §206 do Athenäum: "Um fragmento tem que ser como uma pequena obra de arte, totalmente separado do mundo circundante e perfeito e acabado em si mesmo como um porco-espinho". O que parece ocorrer com a escrita é uma forma de reunião-dispersão, na medida em que se dinamita o discurso em pequenos pedaços isolados e autossuficientes, mas que, em um instante posterior, ganha alguma forma de agrupamento - na forma de livro.

A aparente desordem de ideias causada pela descontinuidade e pelos intervalos configura em um olhar sobre um determinado livro ou ensaio estratificado - um desarranjo ordenado, isto

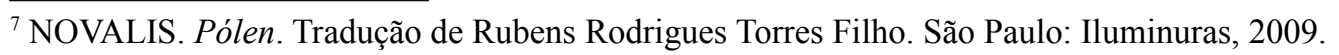


porque é inevitável que os fragmentos se sucedam, tomem algum tipo de formato sequencial, mas que se dá de forma espontânea, não intencional e essencialmente não manipuladora. $\mathrm{O}$ desejo escritural e filosófico se aproxima assim muito mais de uma interação, do que de uma dominação.

Um extrato de L'Écriture du Désastre expõe bem a percepção de Blanchot, em consonância com F. Schlegel:

A exigência fragmentária, exigência extrema, é primeiramente creditada preguiçosamente como restrita aos fragmentos, esboços, estudos: preparações ou dejetos do que ainda não é considerado uma obra. Que ela possa atravessar, reverter, transformar a obra em ruínas, pois esta é totalidade, perfeição, realização "de algo", a unidade que se completa nela mesma. Aqui está o que apresenta F. Schlegel, mas que finalmente o escapa, sem que possamos the censurar, este desconhecimento que nos ajudou, e que nos ajuda ainda a discernir no momento exato onde nós o dividimos com ele. (BLANCHOT, 1980, p.98-99, tradução nossa $^{8}$ )

O pensador francês realiza um elogio a F. Schlegel, porém deixa no ar uma espécie de vacilo cometido pelo filósofo de Iena, talvez pela presença da vontade de retorno a um Todo fílosófico. Blanchot evidencia finalmente três pontos que parecem empurrar os fragmentos em direção aos aforismos tal qual praticados por Nietzsche, traçando então uma "linha-torta" que ligaria o pensamento do fragmentário, através dos estímulos que toma para si e que serão carregados para a escrita do desastre.

1) a considerar o fragmento como um texto concentrado, que tem seu centro em si próprio e não no campo que com ele constituem os outros fragmentos; 2) a negligenciar o intervalo (espera ou pausa) que separa os fragmentos e faz dessa separação o princípio rítmico da obra e sua estrutura; 3) a esquecer que essa maneira de escrever não tende a tornar mais difícil uma visão de conjunto ou mais frouxas relações de unidade, mas a tornar possíveis relações novas que se excetuam da unidade, assim como excedem o conjunto. (BLANCHOT, 2010, p.112)

\subsection{Paradoxo fragmentário-Nietzsche}

Assim como em Schlegel, Blanchot encontrou em Nietzsche um pensamento de ruptura, dando prosseguimento à busca por um pensamento-outro, que apontasse para diferentes direções àquelas já entregues pelo convencional, e por toda uma tradição literária-filosófica. Algumas

\footnotetext{
${ }^{8}$ Tivemos como inestimável auxílio a tradução, ainda não publicada, de L'Écriture du Désastre realizada por Eclair Antonio Almeida Filho e Amanda Mendes Casal. No entanto, em alguns momentos, optamos por fazer algumas alterações, nestes casos indicamos uma tradução própria, quando não, a tradução é a dos tradutores mencionados.
} 
características encontradas na escrita e no estilo, algo tão caro a Nietzsche, se infiltraram em Blanchot, que colheu do pensamento de cada autor aspectos que pareciam circundar suas concepções.

Para Nietzsche, a escrita - no processo de transposição de um pensamento para a linguagem - teria necessariamente que passar por um lugar de experimento e jogo, o que acarretava por vezes na impressão de um inacabamento (principalmente em suas obras mais aforísticas e fragmentárias). Em sua escrita não há privilégio garantido ao estilo que busca a perfeição coerente e coesa.

A primeira instância que parece atrair Blanchot na direção do pensamento de Nietzsche é a procura por uma escrita que tentasse a todo custo e a todo momento escapar da própria linguagem, daquela já viciada, dominada e domesticada pelo Humano9 ${ }^{9}$ Instante limítrofe e questão mordaz: como a escrita poderia escapar de sua própria matéria, daquilo que a forma e a constitui? Tudo parece se dar como se, a partir de aspectos nietzschianos que neste subcapítulo evidenciaremos, Blanchot se esforçasse por devolver uma força pertencente à linguagem, que o Humano, com suas vontades controladoras de significação e de certeza, acabou por encurralar. Em um movimento de mútua ajuda, tanto o escritor-filósofo quanto a linguagem se esgueiram para se desviarem do discurso e da consciência - do que seria puramente humano:

O que importa a Nietzsche, com clareza cada vez maior a partir de Humano Demasiado Humano, é investigar essa lacuna da linguagem, os processos que a ela escapam, e devem escapar, porque mesmo os filósofos permanecem presos nas redes da linguagem. $O$ incessante fluir e tornar-se outro, a multiplicidade de pensamentos e sentimentos que permanecem encobertas sob a consciência... (HARTMANN, 2003, p.39)

Uma das ferramentas utilizadas por Nietzsche para deslocar a escrita filosófica e perturbar suas significações foi o uso de metáforas e analogias, o que configurava um ato de aproximação da filosofia com a literatura, sem a criação de posições hierárquicas ou usurpadoras. Para o filósofo alemão, a metáfora opera no sentido de aproximar ciência, teoria e vida, e ainda de anular a mera oposição entre o especulativo e o prático. Afirma Gilles Deleuze (1976, p.26):

O poema e o aforismo são as duas expressões metafóricas de Nietzsche; mas estas expressões estão numa relação determinável com a filosofia. Um aforismo considerado formalmente se apresenta como um fragmento $^{10}$, é a forma do pensamento pluralista; e, em seu conteúdo ele pretende dizer e formular um sentido. O sentido de um ser, de uma ação, de uma coisa é o objeto do aforismo.

\footnotetext{
${ }^{9}$ A utilização da letra "H" maiúscula estará sempre se referindo ao Humano que busca manipular, controlar e impor a razão e a moral, repelindo e ignorando outras forças que podem se fazer presentes na filosofia, na arte e na vida.

${ }^{10}$ As palavras e frases destacadas na edição por nós utilizada deste livro de Deleuze, Nietzsche e a filosofia, se encontram originalmente em negrito. Optamos por colocá-las em itálico para manter a formatação da dissertação.
} 
É com seu enigmático personagem Zaratustra que Nietzsche atinge o extremo embaralhar entre as noções de literatura e filosofia; há efetivamente um impasse entre estudiosos e comentadores na hora de classificar o Assim falou Zaratustra. Outro fator pertinente a essa íntima relação está na incorporação de uma dada "irresponsabilidade" própria à ficção, mas que pode ser absorvida e tida como aprendizado para a filosofia e a teoria, na medida em que abre a elas um novo campo de possibilidades, livrando-as até de uma espécie de julgamento moralista que pode haver perante os escritos. Ainda segundo Deleuze (1976, p.17):

Um novo ideal, uma nova interpretação, uma outra maneira de pensar, são as tarefas que Nietzsche propõe para si. "Dar à irresponsabilidade seu sentido positivo". "Eu quis conquistar o sentimento de uma total irresponsabilidade, tornarme independente dos elogios e da reprovação, do presente e do passado". A irresponsabilidade, o mais nobre e mais belo segredo de Nietzsche.

Com Nietzsche ganha bastante importância a ideia de uma aproximação radical entre a vida, a filosofia e a literatura, sendo todas tidas como resultados de produções, de invenções, e que, portanto, seria condizente viver como quem escreve ou filosofa. O que se realiza, em todo caso, é uma criação de si, seja ela em ser social, escritor ou filósofo. Quando a vida se transveste em literatura ou filosofia, e vice-versa, aspectos inerentes a cada uma delas invade as outras, por exemplo, quando um especulativo próprio à ficção é transportado para a vida e acaba gerando um escape frente a forças opressoras de controle maniqueísta (não se trata de ser só uma coisa ou outra, só falso ou só verdadeiro). Alexander Nehamas (2002, p.207, tradução nossa) cita Nietzsche ao afirmar que "tanto o que é criado como o agente criador são ficções". E ainda, mais adiante:

A obra, seja de um artista ou de um filósofo, inventa a pessoa que a criou, que se supõe que a tenha criado: os "grandes", tal como têm sido venerados, são fragmentos posteriores de uma ficção menor e miserável. (ibid., p.277, tradução nossa)

Uma afirmação deste tipo já parece iniciar um movimento maior de liquefação, ou ao menos de diminuição da importância da figura do autor, da ideia de um criador máximo de uma obra. Dupla necessidade fragmentária: ontológica e prática (GARRIGUES, 1995, p.349), já que não poderia ser pautada em nenhum modo anteriormente realizado, exigindo sempre do seu proto-autor, sujeito que não procura mais a confirmação e obrigação inexorável do reconhecimento de sua presença, uma constante reconstrução e ressignificação. Esta constatação incide no processo (já que nos românticos a ideia do autor, do gênio romântico impedia tal afirmação) no qual o autor tenta 
suavemente se retirar (movimento que será excessivo em Blanchot, podendo dizer de um esfacelamento), para evitar as deturpações do Humano.

Minha profunda indiferença relativamente a mim mesmo: não quero obter proveitos dos meus conhecimentos, nem fugir aos prejuízos que eles me causam.

- Entre estes há o que podemos chamar a corrupção do caráter; esta perspectiva está fora do assunto: sirvo-me do meu caráter, mas não penso nem compreendê-lo nem mudá-lo, — o cálculo pessoal da virtude não penetrou, um único instante, em minha mente. Parece-me que se fecham as portas do conhecimento quando nos interessamos em nosso caso particular — ou até na "salvação de nossa alma"!... (NIETZSCHE, 2011, p.473)

Este distanciamento do autor para consigo acaba por afastar também leituras excessivamente psicologizantes e biografismos, hábitos e práticas tão comuns na literatura e na filosofia. Evidentemente para Nietzsche estes fatores apenas empobrecem o trabalho de um pensador. Para o filósofo alemão o "eu” transfigurado no vulto do autor é algo que passa por uma ação constante de construção e destruição - desta forma uma ideia de "experiência pessoal" ganha outros contornos.

Além disto, a filosofia nietzschiana se mostrou, paulatinamente, receptiva e simpática ao paradoxo, sendo este um dos primeiros fatores que pareceram atrair Blanchot (baseado em suas análises em artigos/ensaios sobre o filósofo alemão). $\mathrm{O}$ paradoxo se torna personagem de importância capital no ato do pensamento, na medida em que engendra primeiramente a capacidade de fuga frente toda a tradição do discurso e das narrativas convencionais - apoiadas sempre na lógica e no significado, e dependentes austeros de uma linguagem mantida sob controle. Neste ponto o paradoxo se desgarra da noção contraditória: baseada na mera oposição de duas afirmações ditas opostas. Torna-se possível habitar estes dois locais, inclusive aproximando-os: "Não queremos apenas ser compreendidos ao escrever, mas igualmente não ser compreendidos" (NIETZSCHE, 2001, p.284).

No texto de Nietzsche o paradoxo e a contradição estão no fato de que o pensamento não se encontra somente em seus aforismos, mas no que ele também não contém, em um diálogo com o que está para além do texto: o filósofo se coloca finalmente - e talvez pela primeira vez - em xeque. A própria vontade de criação dos fragmentos já nasce de uma delicada transgressão - romper com formas anteriormente praticadas.

Os paradoxos são ferramentas que afastam também uma vontade sistêmica, posto que são capazes de erigir e destruir um sistema ao mesmo tempo. Há neles uma capacidade de atacar suas próprias convicções, colocando o autor e seu texto em posição de constante e permanente risco, inquietação. Segundo Blanchot (2007, p.96) ao comentar Nietzsche: "Contradizer-se é o movimento essencial de seu pensamento; cada vez que ele afirma, a afirmação deve ser relacionada à afirmação 
oposta". Nisto reside a importância do paradoxo, a de uma não eliminação de fatores externos ao texto, se posicionando distante perante uma Verdade absoluta - ele não basta por si só (o que amplia a perspectiva romântica do fragmento). São nestes fatores externos que Blanchot acredita estarem a riqueza da filosofia de Nietzsche, no que de alguma forma ele faz escapar da linguagem e do texto:

Blanchot já exprime o núcleo essencial de sua própria leitura de Nietzsche afirmando que a influência do filósofo não se reduz às suas teses mais conhecidas e aos seus efeitos mais visíveis, mas reside essencialmente no que escapa recorrentemente ao comentário sábio, na sua porção de acontecimento filosófico e estilístico irredutível ao conteúdo manifesto. (ANTONIOLI, 2010, p.104, tradução nossa)

Nietzsche amplia o horizonte da filosofia para um chamado perspectivismo frisado por Alexander Nehamas, que está ligado intimamente com a noção do estético, de estilo, na forma do pensamento e do exercício da escrita. Este perspectivismo está concentrado em uma arte da interpretação, na abertura para leituras diversas que visam gerar novos sentidos, para além de explicações diretas. Na filosofia, assim como na literatura e nas artes em geral, o ser humano transportou uma necessidade de clareza, um automatismo de sua incorporação, sem refletir se esta era realmente uma obrigação na prática destes campos, e é aí que Nietzsche questiona a própria intenção do autor de entender-se e fazer-se entender. Chega mesmo a duvidar de si, algo que teoricamente seria um grande equívoco e um "tiro no pé" para a compreensão da formação de um filósofo durante toda a história da filosofia ocidental - até fins do século XIX.

Para Nietzsche, a objetividade de um filósofo deve estar voltada a uma indiferença moral a respeito de si mesmo, quanto às consequências positivas ou negativas de sua obra (algo que fora com o tempo melhor aceito quando o caso era a literatura, devido à sua capacidade imaginativa, de permissão para uma criação ilusória, por vezes absurda - paradoxal - e irresponsável). Para o criador do Zaratustra, o filósofo (assim evidentemente seria também com o escritor - já que a confusão entre filosofia e literatura em Nietzsche se dá por vezes tão intensamente) deve possuir uma falta de escrúpulos no emprego do que chama de "meios perigosos"; a complexidade do caráter, para além de maniqueísmos (para além do bem e do mal), chega enfim a ser considerada como trilha aberta ao desbravar do filósofo. Os processos de ressignificação da linguagem e do pensamento em Nietzsche são constantes, como no caso da incorporação do erro: a escrita como uma engrenagem errante.

As capacidades de contradição e descontinuidade, por exemplo, pressionam o texto para fora até das noções de estilo, daí o porquê também de nos referirmos ao fragmento como escrita da multiplicidade. É curioso como um texto pode esconder - e revelar apenas através de flashes 
repentinos e alucinados, frames de milésimos de segundo - algo que ele contém, mas não visível ou claramente em si.

A partir de mais uma citação de Manola Antonioli podemos notar um salto dado quanto à questão do fragmento ocorrido a partir de Nietzsche:

A palavra fragmentária (...) manifesta a disjunção, a descontinuidade, a interrupção. Neste sentido, ela não é somente um procedimento estilístico: um texto de aparência perfeitamente organizada, coerente e contínua pode esconder uma escrita profundamente fragmentária, já que uma obra escrita sob a forma de aforismos e de fragmentos pode a todo momento reestabelecer a continuidade e a totalidade que ele parecia querer escapar. (ANTONIOLI, 2010, p.106, tradução nossa)

F. Schlegel, apesar de se embrenhar na novidade do fragmento, possuia ainda a noção de gênero (e de totalidade, na busca de um Uno, como vimos) bastante viva, ideia que em Nietzsche começa a se romper mais efetivamente rumo a uma ideia mais radical de hibridização, libertadora da potência fragmentária.

Há um enriquecimento das reflexões, sondagens contraditórias de Nietzsche - e assim também Blanchot as pensa -, ideias que não pretendem simplesmente opor-se, mas justapor-se, convivendo assim mutuamente, sem necessariamente eliminar aquilo que lhe pode ser contrário. Em nossa visão, Nietzsche ignora o recorrente e clássico significado da contradição como mera oposição, dando-lhe assim novos contornos. Anna Hartmann indica (2003, p.30): "Segundo a interessante observação de Blanchot, dois textos aforísticos podem se opor mas, ao mesmo tempo, eles se colocam um ao lado do outro, se justapõem, criando entre os aforismos uma infinidade de significações". Notamos como fica marcado um local compartilhado por essas significações, copresenças que fundam um corpo vivo escrito, dando um caráter de organicidade à obra.

A noção de um todo, bem acabado e fechado em si, também é dissolvida perante o paradoxo, dando lugar a unidades múltiplas (fragmentos/aforismos), a partir de Nietzsche. O filósofo alemão parece enfim desenvolver uma arte do paradoxo que está imersa em sua genealogia perspectivista, onde as interpretações, as leituras, buscam gerar novos valores - uma transvaloração. No pensamento, a contradição se coloca como aquela ferramenta de tortura em que cada membro do corpo de um homem era amarrado por cordas e ligados a cavalos que saiam em disparada em diferentes direções, acabando por esquartejá-lo. Ao contrário do método cruel de violência, na escrita seu resultado é o de estender e expandir as possibilidades do pensamento (e há também o perigo de romper? Certamente. Quando ocorreria este rompimento? - uma pergunta que resta por responder).

Há ainda na própria gênese, na fundação da ideia de um sistema fragmentário, algo de 
paradoxal, já que, como dissemos, a noção de sistema vigente até o século XIX implicava em plena coerência - garantia do entendimento lógico-racional. Portanto, é inevitável que o paradoxo brote incessantemente dentro da fala fragmentária, através de movimentos espontâneos que alimentam o pensamento. A contradição da qual Nietzsche e Blanchot falam é aquela que finalmente se descola do estatuto da pura negação (sem, no entanto, se furtar completamente dela). Não residem mais nela polos positivos ou negativos, excludentes entre si, mas sim posições de coexistência. Esta constatação pode levar rapidamente a uma ideia de superação de dualismos, porém uma simples substituição de dicotomias diz pouco. Há algo por trás do paradoxo e da descontinuidade (como veremos a frente) que vai além da mera oposição à coerência e ao contínuo/linear. O contraditório ronda o hibridismo dentro de um texto, não permitindo que lhe seja firmado um gênero plenamente estabelecido, pois, caso isto ocorresse, o texto se enquadraria novamente dentro das amarras do discurso que visaria uma completude. Todo gênero já parte de uma predisposição restritiva - aquela que já se inicia com metas maiores, com objetivos e finalidades firmadas e impostas.

Com a valorização do paradoxo, a dúvida e o enigma atravessam também o pensamento nietzschiano. Deixar indeciso, vacilar, não é mais um atributo considerado como fraqueza, como tradicionalmente taxado, mas sim como a substituição do significado de "errar" no sentido do erro, fracasso, por aquele em que "errar" diz respeito à errância, a movimentos incessantes transportados para a escrita. O filósofo alemão nos ensina a apreciar o erro. Diz Blanchot (2007, p.125): "Nietzsche busca pouco a pouco libertar o pensamento relacionando-o àquilo que não se deixa compreender nem como claridade, nem como forma". E mais adiante:

Assim, pedaços, fragmentos não devem surgir como os momentos de um discurso ainda incompleto, mas como essa linguagem, escrita da ruptura, pela qual o acaso, ao nível da afirmação, continua aleatório e o enigma se liberta da intimidade de seu segredo para, escrevendo-se, expor-se como o próprio enigma que mantém a escrita, porque esta o retoma sempre na neutralidade de seu próprio enigma. (ibid., p.135)

Em Nietzsche podemos perceber ainda um primeiro sinal, espécie de salto, de algo que será fundante no pensamento de Blanchot - sempre em ligação íntima com a escrita e a literatura - a questão do apagamento do sujeito. O filósofo alemão, ao invocar o deus Dionysos e o poeta Zaratustra, forças ébrias e enérgicas, inicia um processo de dissolução do sujeito, que se entrega à desrazão, eliminando aos poucos sua imagem. A figura do autor em Blanchot, que se confunde e como que se liquefaz na linguagem - em um livre jogo onde esta pode também se fazer presente, para além de um controle Humano -, se fará atuante em uma impossibilidade (o desafio de escrever sem se colocar), mergulhado em uma escrita de ruptura, em direção à neutralidade que desfaz $o$ lugar assegurado e dominador da parte e da ordem de um sujeito identificável e reconhecível. Neste 
momento podemos observar uma diferença de algum modo drástica em comparação com o fragmento schlegeliano: para os primeiros românticos alemães, o autor e o sujeito, um gênio romântico, ainda era dotado de suma importância, o Humano ainda estava carregado do que podemos chamar de vícios autocentrados (provavelmente este era um dos pontos no qual se apoiava Blanchot quando afirmava os limites do pensamento romântico, de fatores que o tornava restritivo).

O pensador francês chega inclusive a se perguntar se não seria o próprio caráter demasiado humano (para além de uma compreensão corrente do Humano) incompatível com o fragmento e sua capacidade de comunicação. Diz ele:

...haveria incompatibilidade entre a verdade do fragmento e a presença dos homens? Será que onde há homens é proibido manter a afirmação do acaso, a escrita sem discurso, o jogo do desconhecido? O que significa essa incompatibilidade, caso a seja? De um lado, o mundo, a presença, transparência humanas; do outro, a exigência que faz tremer a terra, "quando retumbam, criadoras e novas, as falas, e o deuses lançam os dados". Ou, para sermos mais precisos, será que os homens deveriam de algum modo desaparecer para comunicar? (BLANCHOT, 2007, p.136)

Neste trecho tão rico, observa-se que Blanchot coloca em xeque as questões que parecem mais caras para ele naquele momento no que atravessava o fragmento, bastante influenciado por Nietzsche, pois é ele quem "identifica o acaso ao múltiplo, aos fragmentos, aos membros, ao caos: caos dos dados que sacudidos e que lançamos. Nietzsche faz do acaso uma afirmação" (DELEUZE, 1976, p.21). É possível identificar claramente o porquê da dificuldade do Humano em lidar com o acaso e o caos que floresce por meio da desordem, do fragmentário. Afirmar-se por meio desta condição não é tarefa fácil, posto que se trata de outro tipo de afirmação, onde o escritor/filósofo não busca simplesmente uma legitimação autoafirmativa. Toda a base racional, da tradição europeia na qual estamos inseridos, repele aquilo que Nietzsche e Blanchot parecem perseguir. Voltamos então à penumbra de Dionysos, já que talvez apenas ele pudesse libertar o Homem do cárcere que ele próprio construiu para si, no qual se inseriu temendo forças inumanas, e que majoritariamente continua a habitar, durante décadas, séculos de filosofia, literatura e arte.

Em Nietzsche, uma escrita da ruptura é expressada através dos aforismos, locais onde o filósofo encontra abrigo para a elaboração de seu estilo, possuindo algumas características em comum com os fragmentos de F. Schlegel. Dentre estas estão, podemos citar destacadamente, a descontinuidade e o inacabamento. Escreve Anna Hartmann (2003, p.40):

Diferentemente do modo de expressão linear e sistemático de grande parte das obras filosóficas, os aforismos se ligam uns aos outros por vazios e lacunas. Nesse tipo de escrita, a relação entre os aforismos não é de soma ou degraus, aonde um 
pensamento supere e vá além do seguinte. A escrita aforística é uma espécie de experimento e de pesquisa do pensamento.

Assim como nos fragmentos, o aforismo faz com que cada parte se descole da obra, ao mesmo tempo que é componente dela, dando assim maior liberdade de absorção nas possibilidades de leitura.

A escrita de Nietzsche não se reduziu apenas aos aforismos, já que sua obra se apresenta como fragmentária por excelência. Tendo produzido uma vasta coleção de fragmentos, aforismos, cartas, poemas, deixou pelo caminho rascunhos de todo tipo, configurando assim um quebra-cabeça múltiplo, algo que ainda faz com que os estudiosos de seu pensamento entrem em infindáveis labirintos na tentativa de desvendar este autor tão complexo. Sua variedade estilística o difere, confundindo-o e distinguindo-o da tradição filosófica anterior a sua produção. $\mathrm{O}$ movimento na escrita de Nietzsche se dá na recorrente incorporação e abandono de estilos. Esta característica se aproxima do que afirmou o filósofo e historiador da arte Arthur Danto ao dizer que: "a estrutura de um estilo é como a estrutura de uma personalidade" (apud NEHAMAS, 2002, p.57, tradução nossa). Mais uma vez temos a analogia e o estreitamento da relação entre arte e vida, movimento de troca e mistura disparado por Nietzsche no qual "a arte afirma a vida, a vida se afirma na arte" (DELEUZE, 1976, p.28).

Este olhar examinatório, e de investigação do pensamento, se encontra na escolha de F. Schlegel pela fala fragmentária, escrita que sonda assuntos diversos, sempre permeada pela arte e pela poesia. A diferença principal entre os fragmentos de Schlegel e Nietzsche está justamente na busca por um escape ao Humano, principalmente através do paradoxo, como trabalhado acima. Pode-se identificar um conjunto de fragmentos e aforismos como um arquipélago que, intermeado pelas águas, liga suas ilhas dentro de uma reunião em dispersão. A descontinuidade de um aparente discurso, que logo se esvanece, dá lugar a unidades múltiplas. Isto significa que cada uma dessas "ilhas" possui em sua natureza uma biodiversidade e riqueza próprias. Diferentemente do grupo de Iena, o fragmento já se apresenta então com outra postura frente a ideia de unidade e todo a partir de Nietzsche. Citando Blanchot (2007, p.120): "Linguagem: a própria afirmação, aquela que não mais se afirma em razão nem em vista de Unidade. Afirmação da diferença, mas no entanto jamais diferente. Fala plural".

Dentro desta descontinuidade, sucessão espiralada de fragmentos/aforismos, geradora da dissolução da retórica e do sujeito, é possível remeter ao eterno retorno de Nietzsche, conceito admirado e muito trabalhado pelo pensador francês. A noção de desastre em Blanchot, que será trabalhada no próximo capítulo, parece inclusive ressoar a partir de uma espécie de hereditariedade do eterno retorno. As noções (que chamaremos adiante de componentes ou elementos do desastre) 
trabalhadas por Blanchot se avizinham às de Nietzsche na medida em que se fundam a partir de um desconhecido, escapando do conhecimento, da ideia de domínio que pode haver na criação de conceitos. Ao comentar o eterno retorno, Blanchot já estará mesmo como que falando do desastre:

Por que o pensamento do eterno retorno, pensamento do abismo, é, naquele que o anuncia, um pensamento sem cessar adiado, desviado, como se fosse o desvio de todo pensamento? Eis aí o enigma e sem dúvida a sua verdade (...) [o eterno retorno] conduziu-nos a refletir sobre o tempo, a circularidade do sentido, o fim da história: a ausência do ser como recomeço.

O pensamento do eterno retorno mantém-se estranho em seu velho absurdo. Ele representa a vertigem lógica de que Nietzsche não podia escapar. (BLANCHOT, 2007, p.109-110)

O conceito do eterno retorno realiza saltos mortais em várias direções, fluxos que se estendem pela vida por todas vias temporais. O que atrai certamente Blanchot é este caráter de confusão temporal, que ligeiramente esquiva o tempo de influências marcadamente históricas e demarca uma transição, em constante condição fronteiriça. O eterno retorno diz respeito a acontecimentos que escapam da sua própria temporalidade, levando-o a outras instâncias, não há mais a distinção de um começo e de um fim demarcados. "O eterno retorno do mesmo é então o pensamento-limite de um novo regime da temporalidade como temporalidade do acontecimento, (...) o eterno retorno nos convida à pensar a dissimetria da repetição mesma" (ANTONIOLI, 2010, p.109, tradução nossa). Sua reverberação na escrita pode, por exemplo, estar relacionada com a falta de uma linearidade narrativa/discursiva e no discreto desaparecimento de uma voz narrativa, e é por tais aspectos que este conceito nietzschiano se torna essencial para Blanchot, principalmente quando este tratará de noções próprias à sua escrita do desastre, tais como a passividade e o neutro. A forma como o pensador francês adota os conceitos de Nietzsche parece se aproximar de uma chamada cosmologia, ou seja, de um processo que é disparado e que envolve o universo, as forças que orbitam toda a vida, da luz das estrelas aos acontecimentos telúricos - afastando assim, definitivamente, qualquer interpretação metafísica, ou transcendental, para o pensamento nietzschiano.

A ausência de uma finalidade, da busca por um término, também aproxima o eterno retorno da escrita fragmentária (e posteriormente do desastre), segundo Nietzsche (2011, p.6): "Negamos as causas finais: se a existência tendesse ao fim, a esse fim já teria atingido". Retira-se assim a exigência do final, se ele existe, e quando existe, será apenas como estágio que precede um (re)início, de onde provém a ideia de um círculo vicioso, de um incessante recomeço. $\mathrm{O}$ eterno retorno abarca uma ideia de movimento, de devir, o que será incorporado na escrita em forma de fluxo, ou melhor, do que adiante chamaremos de fluxografia. 
Não se pode negligenciar tampouco, quando tratamos do eterno retorno, a proximidade que este conceito possuiu com a própria condição física e mental de Nietzsche na época em que o concebeu. A relação desta noção com a loucura e a desrazão é evidente (sendo este tema de extrema importância nesta pesquisa ao estudarmos mais a frente uma dita comunidade da desrazão na literatura brasileira). O eterno retorno leva o ser a pensar a vida e o universo em termos limítrofes, ele se dá em estado revelatório e delirante.

Maurice Blanchot persegue também o conceito do eterno retorno de Nietzsche na direção em que o filósofo Gilles Deleuze ${ }^{11}$ descortinou: o da valorização de uma paixão da, e pela, diferença. Isto indica não somente um retorno de algo que já aconteceu, em movimentos necessariamente cíclicos, mas sim o da repetição da diferença, do que diferencia. Como se apresentaria então esta diferença na escrita? Estes pensadores apontam prováveis respostas para esta questão, afirmando sua possibilidade dentro de uma impossibilidade, de um impasse criador, que transita exatamente por estas vias, a saber: o fragmentário, a descontinuidade (quebra do discurso), o paradoxo, o inacabamento, o enigma etc. Pensar o espaço da literatura, e os artifícios que tem em mãos, em direções diferentes das anteriormente escolhidas. Blanchot (2007, p.138) afirma: “Articular o vazio, é por aí que os signos de espaço - pontuação, acento, escansão, ritmo (configuração) -, preliminar de toda escrita, fazem o jogo da diferença e estão comprometidos com seu jogo". O pensador de L'Écriture du Désastre busca devolver à linguagem a possibilidade de se colocar em um escrito ${ }^{12}$, de expor o que dela mesma emana, na atenuação do controle Humano.

É inevitável pensar novamente na relação da escrita com o tempo, que sofre um deslocamento na sua forma de ser pensado, se tornando uma cronologia embaralhada ou uma descronologia. Este tempo diz respeito à eternidade do instante, ao que pode se ligar ao todo plural, ou à unidade múltipla do fragmento. Os aforismos de Nietzsche carregam verdades anunciativas, mas só a partir de sua posição presente. Mais uma tradição do pensamento é aqui desnorteada: a noção de tempo e história. Eventos históricos são incorporados, mas nunca a partir de uma vontade de demarcação de um tempo fixo e plenamente estático, não se trata de refundar uma nova história, posto que este seria mais um ato Humano.

Perseguindo esta escrita da ruptura, que se engendra em níveis variados dentro do texto descontinuidade lacunar, paradoxo, inacabamento - Blanchot escreve:

Essa perseguição que é a ruptura, essa ruptura que não interrompe, essa perpetuidade de uma e de outra, de uma perseguição sem acesso, nem progresso de um tempo, nem imobilidade de um presente, perpetuidade que não perpetua nada,

\footnotetext{
${ }^{11} \mathrm{O}$ que fica evidente nos dois livros que escreveu a partir do filósofo alemão: Nietzsche e a filosofia (1962) e Nietzsche (1965), além de Diferença e Repetição (1968).

${ }^{12}$ Destas inquietações surgem primeiramente e sobretudo O Espaço Literário (1955) e O Livro por Vir (1959).
} 
não durando, não cessando, retorno e desvio de um atrativo sem atração: será isso o mundo? Será isso a linguagem? O mundo que não se diz? A linguagem que não tem o mundo a dizer? O mundo? Um texto? (BLANCHOT, 2007, p.134-135)

Em Nietzsche a escrita é traçada por meio da tensão criadora entre o rigor apolíneo e o torpor dionisíaco, nela é de suma importância a questão do ritmo, que deve fluir como em uma dança, com uma finalidade sem fim. Esta espécie de escrita-bailarina que, próximo do que havia sido formulado pelos primeiros românticos alemães, mas já com outros contornos, deve combinar pensamento e poesia.

Acrescentados a todos estes fatores anteriormente trabalhados o que parece ser o maior estímulo, os ecos de Nietzsche em Blanchot, diz respeito ao modo como o filósofo alemão pensava a filosofia, a escrita e a vida. A relação entre teoria e prática começa enfim a entrar em movimento de simbiose, a prática filosófica/literária não faz mais referência apenas em breves momentos à prática cotidiana (tida até como banal, irrelevante), ambas passam a se entrelaçar, a se confundir, ao ponto de Blanchot (2007, p.99) destacar que Nietzsche: "não se satisfaz em conhecer, ele deve tornar-se aquilo de que fala". O sujeito prático, físico e vivo, transtornado e tornado o seu próprio pensamento, embaralhando, perturbando e transformando mais uma vez as noções de teoria e prática. A teoria: o inseparável da vida, sua extensão. Esperamos que isto fique mais claro no andamento da pesquisa, na medida em que o pensamento blanchotiano - marcadamente esboçado no desastre - for sendo mais especulado, juntamente com o que chamaremos de testemunhos da desrazão.

Um fragmento do famigerado livro póstumo do filósofo alemão: Vontade de Potência, concentra boa parte das ideias aqui levantadas, abrindo ainda caminho para o desastre em Blanchot. Neste trecho fica também exposta a confusão mais uma vez entre vida e arte, teoria e prática. Diz Nietzsche (2011, p.136-137):

E sabeis o que é para mim o "mundo"? É mister que vo-lo mostre ao espelho?

Este mundo é um monstro de força sem começo nem fim, uma quantidade de força brônzea que não se torna nem maior nem menor, que não se consome, mas só se transforma, imutável no seu conjunto, uma casa sem despesas nem perdas, mas também sem rendas e sem progresso, rodeada do "nada" como de uma fronteira. Este mundo não é algo de vago e que se gaste, nada que seja de uma extensão infinita, mas, sendo uma força determinada, está incluído num espaço determinado e não num espaço que seria vazio em alguma parte. Força em toda a parte, é jogo de forças e ondas de forças uno e múltiplo simultaneamente acumulando-se aqui, enquanto se reduz ali, um mar de forças agitadas que provocam sua própria tempestade, transformando-se eternamente num eterno vaivém, com imensos anos de retorno com um fluxo perpétuo de suas formas, do mais simples ao mais complexo, indo do mais calmo, do mais rígido e do mais frio ao mais ardente, ao mais selvagem, ao mais contraditório, para consigo próprio, para retornar, depois, 
da abundância à simplicidade, do jogo das contradições ao prazer da harmonia, afirmando-se a si mesmo, ainda nessa uniformidade das órbitas e dos anos, bendizendo-se a si próprio como aquilo que eternamente deve retornar, como um devir que jamais conhece a saciedade, jamais o tédio, jamais a fadiga - : este meu mundo dionisíaco da eterna criação de si mesmo, da eterna destruição de si mesmo, este mundo misterioso das voluptuosidades duplas, meu "além do bem e do mal", sem fim, senão o fim que reside na felicidade do círculo, sem vontade, senão um anel que possua a boa vontade de seguir seu velho caminho, sempre em redor de si mesmo e nada mais senão em redor de si mesmo: este mundo, que eu concebo, quem, pois, possui o espírito bastante lúcido para contemplá-lo sem desejar ser cego? Quem é bastante forte para apresentar sua alma ante esse espelho? (...)

De querer para trás, de querer todas as coisas que já foram? De querer para o futuro, de querer todas as coisas que serão? Sabeis agora o que é para mim este mundo? E o que eu quero, quando quero este mundo?

Quereis um nome para esse universo, uma solução para todos os enigmas?

Uma luz até para vós, os mais ocultos, os mais fortes, os mais intrépidos de todos os espíritos, para vós, homens da meia-noite? Este mundo é o mundo da vontade de potência e nada mais e vós também sois esta vontade de potência e nada mais. 


$$
\begin{aligned}
& 6 \\
& 5 \\
& 5
\end{aligned}
$$

Segundo Capítulo

[ Corporificação do Desastre ]

$$
\begin{aligned}
& 65 \\
& 3,9
\end{aligned}
$$




\section{$\underline{2.1}$ Aspectos/Espectros do desastre}

"No estilhaçamento do universo que experimentamos, prodígio! os pedaços que caem estão vivos."

René Char

A partir do desenvolvimento e da incorporação da noção de escrita fragmentária, e de todo pensamento que girara ao redor do fragmento, Blanchot coloca em processo uma forma singular de escrita: a escrita do desastre. Algumas transformações pontuais sobre os pensamentos trabalhados no capítulo anterior foram realizadas por Blanchot para chegar em uma escrita do desastre que incorporou o fazer fragmentário em sua constituição. Podemos dizer, por exemplo, que o que se apresentava como uma ideia de construção de obra em F. Schlegel passa a se transmutar em desobramento (a dissolução, o esfacelamento de uma ideia de obra, que dá lugar a um desencadeamento de paixões na escrita, em detrimento da busca por uma totalidade), enquanto que em Nietzsche a ideia do paradoxo e do eterno retorno se encarna em Blanchot sob as égides do neutro, da passividade, e da vigília na literatura, pois como dito anteriormente estes conceitos são mesmo como que descendentes do conceito do filósofo alemão.

Apesar do desastre romper com uma marcação, com posições datadas e fixas na história, não há como negar ou ignorar o período no qual o livro L'Écriture do Désastre foi publicado: o ano de 1980. O conceito de desastre, como veremos adiante, aponta para diversas formas de ruptura e de coexistência em espaços fronteiriços, abalos e crises na escrita que se espelham com a condição surgida no decorrer do século XX - na criação e desenvolvimento de diversas práticas literárias -, culminando nos fins do século XX e início do XXI. Reza uma suposta lenda cíclica (uma espécie de eterno retorno?) que o principiar de cada século é sempre marcado pela característica de ser um período de hesitação, que atravessa tensões sociais (geradoras de guerras ou princípios de) e crises identitárias nas várias áreas do conhecimento. O pensador português João Barrento em um texto no qual menciona um artigo de F. Schlegel sobre a ausência de um foco para a cultura na passagem do século XVIII para o XIX afirma: "Parece haver, de facto, nas últimas viragens de século, em que um universo de valores vai chegando ao fim e se desmorona, enquanto o novo emerge, esta consciência aguda da falta de um 'centro"' (BARRENTO, 2011, p. 28). Observaremos, por meio da escrita do desastre, como na passagem do século XX para o XXI fica patente (pois na do XIX para o XX já haviam fortes indícios) o fato de que não se trata mais de uma busca por um centro, mas simplesmente da confirmação da persistência - da cultura, da arte, da vida - em uma ausência nuclear, sem a necessidade da descoberta ou mesmo da busca por um núcleo, espelhado em rupturas 
com verdades vigentes as mais diversas.

Certamente a clássica pergunta lançada: “será possível escrever após Auschwitz?” foi de alguma maneira respondida (uma resposta sem resposta) em L'Écriture du Désastre. Neste livro, o pensador francês afirma como na verdade a literatura realmente não é possível - mas que, ao mesmo tempo, tem nessa impossibilidade a sua forma de perpetuação. A literatura passa a se enunciar pelo esquecimento de um trauma que jamais se deixará fazer esquecido. Neste momento, realiza-se um diálogo permanente com aquela época (com aquele zeitgest), uma era que, por meio do esquecimento, se desprende da história e passa a vagar, suspensa no tempo - e não seria talvez só assim que se torna possível ir adiante? Um fragmento de L'Écriture du Désastre coloca a prova esta afirmação acima, segundo Blanchot (1980, p.80, tradução nossa):

O nome desconhecido, fora da nominação:

O holocausto, acontecimento absoluto da história, historicamente datado, esta queima-total onde toda história se abrasou, onde o movimento do Sentido se abismou, onde o dom, sem perdão, sem consentimento, se arruinou sem dar lugar à nada que possa se afirmar, se negar, dom da passividade mesma, dom daquilo que não pode se doar. Como guardá-lo, mesmo que seja no pensamento, como fazer do pensamento aquilo que guardaria o holocausto onde tudo se perdeu, inclusive o pensamento guardião? Na intensidade mortal, o silêncio fugindo do grito incontável.

Esta época inaugurou definitivamente processos de dissolução cada vez mais visíveis de absolutismos e dialéticas, abrindo caminho para experimentações e multiplicidades nas artes, com o surgimento de movimentos que incorporavam esta ruptura com dualismos e com a própria noção de história como narrativa do Humano. Blanchot vê na segunda guerra mundial o evento que possibilita este descolamento de construção e visão humanista. Diz o pensador francês:

...,pois ater-se a uma coisa suporia que há algo de determinado a que se ater, suporia portanto uma separação nítida de sombra e de claridade, de sentido e de não-sentido e, por fim, de felicidade e de infelicidade, mas como um é sempre o outro e o sabemos, mas numa espécie de ignorância que nos dissuade sem nos esclarecer, não buscamos senão preservar a incerteza e obedecer-lhe, inconstantes por uma falta de constância inerente às próprias coisas... (BLANCHOT, 2007, p.28)

É por meio deste tipo diverso de linha de raciocínio que o escritor de L'Écriture du Désastre parece principiar, através de 401 fragmentos, um pensamento que dá vazão a uma literatura que se pauta na incerteza, e na sua própria impossibilidade - daí advém uma certa difículdade em compreendê-la, em conhecê-la, já que a tradição de nosso pensamento se apoia fixamente na certeza e no conhecimento. 
Blanchot parte de um desmembramento, de uma desintegração da própria palavra desastre (des-astre) para expor a condição deste conceito. No francês "astre" significa "astro", e esta disjunção na composição da palavra dá indício e confere a exposição da perda de referência, marcando uma separação inerente. Des-astre - estar separado do astro, das estrelas. São retirados assim pontos de luminância-guia, garantias para trajetos já assinalados, a partir de um todo do qual já se está desgarrado, em um movimento que ultrapassa formas meramente totalizantes - no desastre ações totalizadoras já não se fazem vontade e garantia. De acordo com Blanchot (1980, p.121, tradução nossa):

O desastre, ruptura com o astro, ruptura com toda forma de totalidade, sem no entanto negar a necessidade dialética de uma realização, profecia que não anuncia nada além da recusa do profético como simples acontecimento por vir, abrindo, todavia, descobrindo a paciência da palavra em vigília, espera do infinito sem poder, aquilo que não se passa sob o céu sideral, mas aqui, um aqui em excesso sobre toda presença. Aqui, onde então? "voz de ninguém, novamente".

É interessante notar como o desastre, apesar de imprimir uma ideia de aporia, não nega a necessidade de uma realização, de uma efetivação. Trata-se então de levantar hipóteses para o tipo de realização no qual se inscreve este desastre - e neste caso estudaremos efetivações artísticas, intercessoras também da escrita.

A escrita que se encontra perdida, sem referência, flutua livremente em um espaço sideral, o espaço literário $^{13}$. Ela está à deriva, fora de órbita. Sua postura é a de violentar o discurso com uma flor (como diz o verso, creditado ao artista plástico Andy Warhol, na canção "Vicious" do músico estadunidense Lou Reed). Esta violência se dá no ataque àquilo que constituiu (e que em larga escala ainda continua a constituir) a base da literatura e da filosofia, mesmo após todas as transformações ocorridas. Vemos aqui uma aproximação essencial do desastre com o fragmento: a operação de quebra e ruptura, a dilaceração do discurso.

O desastre é um desafio. Como captar um pensamento que é da ordem do inapreensível? O que fazer das ruínas que dele soçobram? Peter Pál Pelbart afirma:

(...) o desastre não é maiúsculo, não consiste num evento ruidoso, não pode ser localizado num tempo preciso, nem num espaço delimitado... Ele é o contratempo, o entretempo, o vai e vem, a desordem nômade, a afirmação intensa do fora. (QUEIROZ et al., 2007, p.66)

\footnotetext{
${ }^{13}$ Blanchot publicou em 1955 o livro O Espaço Literário, no qual traça uma espécie de cartografia, concentrando-se na ideia de que a literatura opera em um espaço singular, um território no qual o pensador, o teórico teria que se debruçar tal qual um geógrafo com seus mapas, na identificação de todo um horizonte e paisagens próprias ao local.
} 
Uma outra resposta espectral parece se resguardar aqui: o âmago do desastre se concentra exatamente na falta, na ausência, ele é eterna suspeita. Que escrita seria essa que reside no intangível, no que não é possível pegar com as mãos, manipular, controlar, moldar? É inevitável que a matéria prima textual, a linguagem, também se apresente diversamente. A fórmula semiótica que busca puramente substituir a coisa pela palavra, por meio de uma codificação, não é mais tão exata, já que "a escrita só começa quando a linguagem, voltada sobre si mesma, designa-se, apreende-se, e desaparece" (BLANCHOT, 2007, p.268). O grande incidente causado pela linguagem do desastre é fugir da nomeação, tentar escapar do sentido que parece inerente e aderido à palavra - buscar a diferença dentro do que parece automático. Os processos literários caros a Blanchot incidem na operação de uma abertura para o ressoar de uma voz própria da linguagem, espaço onde possa ser possível enfim “conceder a palavra" a própria palavra: realização de um pronunciamento livre do controle Humano, racional.

“A mediação da linguagem, assassina, é também um desejo de domar o monstro, de fazer com que a Diferença se torne diferente. Este é, por exemplo, o papel do epitáfio: diferenciar a morte na nominação assassina do morto" (GARRIGUES, 1995, p.136, tradução nossa). A escolha da utilização de expressões, das palavras - de um certo glossário-Blanchot - gera também um desconforto, uma inquietação por se tratarem de palavras que apesar de manterem evidentemente alguma relação com seu sentido corriqueiro (impregnadas que estão pelos usos históricos e saturadores) estão a todo momento forçando passagem para outros territórios, abrindo caminho para uma diferença, que exige novas formas de abordagem. Blanchot acaba por transportar a linguagem para a ordem do irreconhecível através do desmoronamento de supostas essencialidades, portadoras da compreensão expressiva e referencial das palavras.

Como dissemos, o discurso, modo tradicionalmente corriqueiro no qual a literatura ocidental se pautou, passa por um processo de desintegração. Sua disposição - acreditada fixa e inexorável é desfeita. Carregando esse caráter da fala fragmentária, o desastre se torna ruína de discurso. Seus códigos, significados, escorregam para territórios indiscerníveis, locais que pensávamos bem reconhecidos, mas que agora nos parecem estranhos. É como se a partir do desastre novos pontos de vista e perspectiva fossem descobertos: um novo olhar é produzido. À escrita do desastre cabe se realizar - como filha/pupila de Zaratustra - na dúvida, no enigma. Hesitar sem êxito. Uma de suas características é a de operar por uma zona de desconforto, já que sua emissão se dá permeada por uma constante sensação de incômodo. A gênese do desastre blanchotiano remonta à inexistência de pontos de apoio marcadamente necessários dentro da tradição da criação literária. A narrativa, o enredo, o desenvolvimento, e/ou o gênero não se fazem mais partes obrigatórias na concepção de um livro (algo que ficará evidenciado quando nos debruçarmos sobre os testemunhos da desrazão). 
Este deslocamento de aportes referenciais que incidem sobre uma ideia de partida para a invenção literária já altera significativamente a maneira como nos aproximamos de suas matérias-primas. Não se pode mais tentar exercer a escrita, e mesmo pensá-la criticamente/filosoficamente, tendo como base os preceitos vigentes até então. Faz-se necessário, portanto, fundar também novos termos de investigação e produção.

Um grande desvio se localiza então na maneira do pensamento atuar. Neste momento, abrese e expande-se o diálogo entre Maurice Blanchot e Michel Foucault (nunca efetivado pessoalmente, tête-à-tête, apenas na memória que vacila ao suspeitar de um contato durante o ano de 1968), uma abertura que acabou por incidir em uma série de meandros, em uma conversa diversificada (infinita?) através de temas como o da linguagem, da história, do fora (exterioridade), entre outros. Aqui nos interessa especificamente a forma como Blanchot segue a trilha arqueológica/genealógica trabalhada por Foucault (muito estimulado por Nietzsche, cabe dizer), ou seja, aquela em que o pensamento se constrói no escavar de uma arqueologia das questões, na identificação do solo próprio a cada um dos temas em voga, o que confere outro diálogo e cruzamento entre estes pensadores, pois incide diretamente na ideia de um pensamento cartográfico, espacial-territorial. A genealogia de Foucault busca a raiz mesma, uma espécie de fundação, formação dos conceitos, para pensá-los e problematizá-los com maior amplidão, tendo em vista suas transformações através dos tempos e o poder que exerce nos seres:

Blanchot vê reconfigurado seu próprio itinerário, à luz da nova arqueologia, expandida em genealogia, no caminho de Foucault. Revela uma familiaridade com a proposta crítica desbravada pela arqueologia, que pode ser entendida como a moldura material e metodológica da análise dos saberes e dos efeitos intrínsecos de seus poderes. Sendo entendida a genealogia como a finalidade da análise, a esfera investigativa onde práticas discursivas e outras são submetidas à intervenção direta de um pensar polivalente e operacional, no modo de arquivar, cartografar e gerar conhecimento (...) (VASCONCELOS, 2004, p.70)

O que cada tradição/época/era (na esteira de uma genealogia que já leva em consideração também uma subsequente noção de historicidade em processo e em leitura) acaba dizendo efetivamente sobre a literatura e a linguagem, por exemplo? Quais são seus efeitos e as forças que entram em colisão proliferante? No caso de Blanchot, tendo em vista a noção de arqueologia, a linguagem seria aquela que tentaria abrir frestas que dariam vazão para outras luminâncias, geradora de novos enunciados na criação de um ser em linguagem tal qual exposto por Foucault. Diz Gilles Deleuze (2005, p.61): 
A tarefa da arqueologia é primeiramente descobrir a verdadeira forma da expressão que não possa ser confundida com nenhuma das unidades linguísticas, sejam quais forem, significante, palavra, frase, proposição, ato de linguagem. (...)

É preciso então rachar, abrir as palavras, as frases e as proposições para extrair delas os enunciados, como fazia Raymond Roussel, inventando seu "procedimento".

Além desta nova postura da linguagem que busca se revelar, abrir-se ao desconhecido, e da ausência de um gênero definido, na escrita do desastre relacionada à literatura, uma trama só pode ser concebida através de fragmentos, e se há alguma esta será necessariamente fragmentária. A narrativa como compreendida dentro da história da literatura - aquela ligada a desenvolvimentos de situações, personagens, conflitos etc. - não será encontrada na literatura posta em evidência e valorizada por Blanchot. Se há uma trama, esta é de outra ordem, transita por territórios não delimitados - e provavelmente indelimitáveis, posto que incessantemente cambiáveis, em estado de devir.

Ainda por isso podemos dizer que a escrita do desastre atravessa uma poligrafia, alternando o tom de seu texto, o que não permite uma efetuação do leitor dentro de ideias como a de gênero, daí a possibilidade de se falar em hibridismo textual - feição fragmentária. Na biologia, o ser considerado híbrido, aquele que é gerado através do acasalamento de duas espécies diferentes, resulta em um ser estéril, que não pode procriar, impedindo assim a proliferação de uma linhagem, a continuação de uma espécie. A escrita do desastre mostra que, na literatura, ocorre o movimento contrário dentro da noção de hibridismo: aqui o "ser literário" (ou o "ser em linguagem" ao qual se refere Foucault) se torna potencialmente fértil, dando vazão a escritos que se expandem em direções múltiplas, abrindo também caminho para pensamentos vários.

Em L'Écriture du Désastre crítica e literatura se fundem, e este hibridismo se faz presente na alternância constante entre reflexões, citações e ficções. Esta miscelânea do texto acaba por alterar e desestruturar a própria forma de apreensão do conhecimento ao ponto de Blanchot (1980, p.73) proclamar: "Fim da teoria que detém e organiza o saber. Espaço aberto à 'teoria fictícia', lá onde a teoria, por meio da ficção, entra em perigo de morte". Esta "teoria fictícia" anuncia uma nova maneira de realização do texto, suspendendo assim barreiras entre forma e conteúdo, teoria e ficção, crítica e literatura - ideia que, como vimos, foi como que iniciada discretamente por F. Schlegel, e levada a movimentos drásticos a partir de Nietzsche. Podemos citar como exemplo de rompimento entre ficção e teoria, no caso mais abrangente da arte no século XX, o início da produção de um cinema ensaístico, capaz de reunir e fundir pensamento e linguagem imagética: são os casos do filmaker francês Chris Marker, e do pensador-ativista Guy Debord (o que lhe possibilitou trabalhar suas teorias quanto à sociedade do espetáculo fazendo uso de ferramentas da arte cinematográfica). Lembramos agora também de Blanchot que "imagina" Foucault ao trabalhar sua teoria, citando 
ainda uma frase do autor de As palavras e as coisas, que disse certa vez (apud BLANCHOT, 2002, p.139, tradução nossa): "Nunca escrevi nada além de ficções e estou perfeitamente ciente disso".

No caso da incorporação de citações ${ }^{14}$ ao texto, Blanchot vê mais uma possibilidade de apreensão da força fragmentária, adicionando camadas diversas a um bloco escrito:

Se a citação, em sua força despedaçante, destrói de antemão o texto do qual ela não foi somente extraída, mas que ela exalta até não ser nada além de uma extração, o fragmento sem texto nem contexto é radicalmente incitável. (BLANCHOT, 1980, p.64, tradução nossa).

Neste trecho, Blanchot compõe ainda um jogo bastante curioso com a palavra no francês “incitable", levando em conta uma ambiguidade que é carregada também para o português, já que esta palavra pode dizer respeito tanto a "incitável", no sentido mesmo de incitação, instigação, quanto a "não-citavél", a impossibilidade de ser (re)pronunciada. A partir disso podemos dizer que o fragmento é uma fala que estimula a citação ao mesmo tempo em que a impossibilita, já que ele próprio já é ruína, pedaço, destroço. Em L'Écriture $d u$ Desastre, o pensador francês também suprime constantemente o nome dos autores das frases, optando por mencioná-los apenas através das iniciais dos nomes, talvez em uma leve tentativa de suprimir ou retirar um pouco a carga de importância da autoria, na aproximação do ser em linguagem de Foucault que "só aparece para si mesmo com o desaparecimento do sujeito" (FOUCAULT, 2009, p.222).

A associação com uma ideia de "escultura literária" (noção comumente ligada à música: as "esculturas sonoras" concebidas por artistas como Stockhausen e John Cage) poderia ilustrar a condição da literatura no desastre. Esta escultura seria mais condizente com uma visão de colagem (lembramos-nos aqui dos cut-ups de W. S. Burroughs, que neste sentido já contém indícios de uma possível escrita do desastre), divergindo de uma simples junção de peças óbvias de um objeto. Se pensarmos na escultura de um corpo humano, ela seria aqui uma junção de partes que não pertencem originalmente à figura humana, ressignificando-o (através de metáforas do inconsciente, de fragmentos urbanos, maquínicos etc.) e acabando por gerar uma nova figura. Com o desastre se escreve como na formação de novos corpos: defeituosos, deformados e fascinantes.

O grande perigo do desastre está em dar-lhe sentido, significado fixo, esquadrinhá-lo, aplicar a ele fórmulas puramente analíticas que entreguem explicações de como foi concebido, de supostos objetivos e propósitos, ou seja, torná-lo uma ciência exata, aplicada. Trair o desastre seria torná-lo objeto, correndo o risco de fazer dele mais um capítulo de modelo ou guia de escrita, isto porque

\footnotetext{
${ }^{14}$ Cale salientar que a citação está se tornando algo recorrente e cada vez mais presente na literatura contemporânea, tendo seu uso transformado em grande recriação, da realização de um remake literário; como exemplo, temos o escritor espanhol Agustín Fernandez Mallo (autor de um remake do livro El Hacedor de Jorge Luis Borges, que teve sua circulação proibida pela viúva do escritor argentino, herdeira dos direitos de sua obra).
} 
atuar dessa forma seria colocar em prática tarefas que ele refuta, e das quais busca evidentemente fugir, escapar. As suspensões que o desastre engendra sob o sentido torna-o de difícil absorção. Segundo Blanchot:

Escrever talvez seja trazer à superfície algo como o sentido ausente, acolher o impulso passivo que ainda não é ainda o pensamento, sendo já o desastre do pensamento. Sua paciência. (...) Sentido que não passa pelo ser, por baixo do sentido - suspiro do sentido, sentido expirado. De onde a dificuldade de um comentário da escrita; pois o comentário significa e produz significação, não podendo suportar um sentido ausente. (BLANCHOT, 1980, p.71)

Pelo desastre é produzido um corpo anônimo que, impossibilitado de se transmutar em matéria ou organismo, busca abrigo na incapacidade do ser. A escrita do desastre seria esta escrita de desejo quase biológico, realização inexorável do ser através da linguagem, ela simplesmente não pode ser evitada - é daí que vem seu distanciamento de objetivos e objetos firmados. Não se escreve para se alcançar algum tipo de êxito (textual, de uma narrativa retórica), reconhecimento (autoral, pessoal), mas por pura necessidade. Lembramos neste instante do personagem Forrest Gump, do filme homônimo de Robert Zemeckis de 1994, que um dia simplesmente decide iniciar uma jornada como um corredor-peregrino, ao entrar em uma sequência de cooper onde as noções de inicio ou fim se diluem. Quando várias pessoas se aproximam e passam a seguir aquele estranho e inútil maratonista, elas o fazem com o desejo de que ele as entregue algum sentido à vida, alguma bandeira a ser hasteada ou a defesa de alguma causa, vontades excessivamente Humanas, carregadas e sedimentadas por humanismos, e que acabam não sendo correspondidas. De maneira similar ao ato deste curioso personagem, a escrita do desastre transita em uma ausência de certezas e finalidades, em um território não teleológico.

A dificuldade de fixar a figura do autor também se dá por este desconhecimento do motivo, não se sabe por que se escreve, não existem justificativas plausíveis ou aceitáveis: “Querer escrever: que absurdo: escrever é a abdicação do querer, como a perda do poder, a queda da cadência, o desastre ainda" (ibid., p.24, tradução nossa). No desastre a escrita alcança um grau máximo de inutilidade, quer dizer, se distancia de um discurso utilitário e aplicável: "escrever é evidentemente sem importância, não importa escrever. É a partir daí que a relação com a escrita se decide" (ibid., p.27, tradução nossa).

A escrita do desastre pode ser considerada como a experiência-limite da qual fala Blanchot, nos ecos de Georges Bataille. Ela carrega cada aspecto da literatura ao seu extremo, embaralhando suas regiões fronteiriças e levando-a a condições limítrofes: todos seus aspectos são suspensos para que ela advenha em seu livre jogo. Parece-nos que para trabalhar com o conceito de desastre, para 
colocá-lo em operação, é necessário ter sempre em mente a frase: "Perigo de que o desastre ganhe sentido ao invés de corpo" (BLANCHOT, 1980, p.71, tradução nossa). O processo do desastre é quase invisível, sorrateiro, por isso talvez a única maneira de torná-lo minimamente possível seja através de seus vultos em livros, filmes, pinturas, fillosofias, músicas etc. Não dar a ele significado, explicação, mas sim perspectivá-lo em produções: sonoras, visuais, de reflexão.

Vislumbramos então uma possibilidade: pensar o desastre a partir de uma visão alquímica, sendo ele uma substância formada a partir de componentes específicos, ditados e manipulados fragmentariamente por Blanchot em L'Écriture du Désastre. Esta espécie de química filosóficoliterária possui evidentemente em sua composição alguns substratos que causam efeitos, em sua maioria colaterais e improváveis. Quais seriam então estes efeitos na escrita? Após a sua ingestão por quais reações passariam o autor e o leitor, por exemplo?

Os elementos/componentes parecem se ligar como em um elo, em anéis de uma corrente. Não será, portanto, uma surpresa se eles se fizerem presentes um no outro, ou mesmo que possam se confundir em dados momentos. Estes elementos do desastre fazem parte de uma mesma engrenagem, participando de uma espécie de reação em cadeia, ou de um efeito dominó, pois a partir do momento em que um deles se faz componente na escrita, os outros também iniciam movimentos de aparição, tendo como que seus dispositivos acionados.

O desastre blanchotiano catalisou uma série de processos de indeterminação dentro da escrita - o que ficará evidente em seus elementos. O vulto da morte ${ }^{15}$ (e da loucura como veremos mais a frente) atravessa também todos estes componentes, e parece em dados momentos se portar como metáfora exemplar do desastre, principalmente por encarnar algo no qual vivemos em constante iminência e da qual não podemos falar precisamente, nem por nós, nem pelo outro, já que, estando vivos, nunca passamos por ela - a experiência da morte é igualmente inapreensível. A partir de Blanchot, Deleuze (1974, p.154) comenta: “a morte é ao mesmo tempo o que está em relação extrema ou definitiva comigo e com meu corpo, o que é fundado em mim, mas também o que é sem relação comigo, o incorporal e o infinitivo, o impessoal, o que não é fundado senão em si mesmo". Quando nos propomos a falar da morte nos jogamos no desconhecido, dizemos de algo que não temos conhecimento. Para Blanchot, devemos pensar e escrever como se morrêssemos, nesta impossibilidade e neste desconhecimento, praticando uma filosofia e uma literatura da quase-morte, do estranhamento, em iminente risco de vida:

Pensar como se morre: sem meta, sem poder, sem unidade e precisamente sem "como" - de onde a nadificação da formulação desde que ela é pensamento, quer

\footnotetext{
${ }^{15}$ Tema recorrente em Blanchot e bastante estudado através de diversos artigos e ensaios (um deles incluído no livro $A$ Parte do Fogo), e mesmo em livros (Pena de Morte e $O$ instante da minha morte).
} 
dizer, pensamento de cada lado, em desequilíbrio, em excesso de sentido e em excesso sobre o sentido - saída, fora. (BLANCHOT, 1980, p.67)

O desastre aponta ainda para lugares pensados como não pertencentes e externos à literatura (e por extensão à arte), mas que aqui são evidenciados como componentes dela, mesmo que se enunciando de um fora, que não é necessariamente externo em termos espaciais, pois se fazem presentes ao ecoar e surtir seus efeitos; ele é deste modo "a exposição da diferença" (GARRIGUES, 1995, p.127, tradução nossa). Em mais uma fuga de dualismos, o desastre é o que "evacua o sim e o não, o sentido e o não-senso, a vida e a morte, o silêncio e a palavra, deportando-nos da intencionalidade para a intensidade, para além ou aquém do ser e da ontologia - o neutro, a pura diferença" (PELBART, 2009, p.222). Pensamos que o desastre atua em um campo postadamente de reversão de tautologias, dado à tarefa de possibilitar o impossível, de alcançar o inalcançável, de confessar o inconfessável.

A seguir visitaremos alguns dos elementos que vemos operados em L'Écriture du Désastre. Reafirmamos que nossa intenção não será de maneira nenhuma a de criar uma ciência do desastre, de torná-la disciplina, mas tão somente de dar algum contorno - ou corpo como quer Blanchot para alguns aspectos que compõem este conceito múltiplo, amálgama filosófico-escritural.

\section{$\underline{2.2} \mathrm{O}$ desastre como substância alquímica: elementos de composição}

\section{Passividate}

O desastre paira sobre um território inabitável, caracteriza-se por se tornar evento sem nunca acontecer perante nossos olhos: nos descobrimos em postura passiva. Ele pertence a um presente sem presentificação, posto que não pode ser atingido. Não vamos de encontro a ele, é ele quem vem ao nosso encontro - nós não conseguimos tocá-lo, mas ele nos toca. Nossa dificuldade maior reside no fato de que estamos acostumados a pensar a passividade somente sob a esfera da inatividade, do que não é ativo. Mais uma vez não se trata de uma dicotomia - da demarcação de posições opositoras. A passividade em Blanchot se aproxima mais da ideia de postura errante. No caso da literatura, em uma escrita que se costura por um fluxo. Sua criação está diretamente ligada ao processo em se dá, não há um pensamento a priori, preconcebido, de uma narrativa, por exemplo, mas sim uma linha que só vai se desenhando a partir do momento em que começa a ser traçada e disseminada. 
Há a passividade que é a quietude passiva (figurada talvez pelo que nós sabemos do quietismo), também a passividade está para além da inquietude, retendo o que há de passivo no movimento fervoroso, desigual-igual, sem parada, do errar sem meta, sem fio, sem iniciativa. (BLANCHOT, 1980, p.31, tradução nossa)

Este movimento escritural febril, incessante e descontínuo, portanto errante, é preenchido por uma fluxografia, onde sua interrupção não se dá por fatores como a falta de coerência e desenvolvimento narrativo, mas simplesmente por um esgotamento, que dá lugar a um novo movimento, que por sua vez só cessa (brevemente ou não - sua duração é variável) através de um novo esgotar. Por conta disso se faz novamente importante aqui a ideia de fragmento, pois estes movimentos acabam por constituir blocos que se dispõe fragmentariamente, modulando-se em frases, parágrafos e/ou capítulos. Os limites da escrita não são bem delimitados, uma espessa névoa povoa suas fronteiras, impedindo-nos de visualizar pontos finais ou iniciais. A repetição também auxilia a configuração desta indiscernibilidade. A fluxografia - o fluxo contínuo da/na escrita engendra uma dispersão narrativa ao mesmo tempo em que a dispensa em um caos de acontecimentos. Aqui, não se escreve com uma intenção, com um objetivo, e esse talvez seja o grande mote catalisador de uma nova transformação na escrita. A partir deste momento é que qualquer intencionalidade dá lugar a uma intensidade (tal como mencionada por Pelbart), e é possível se liberar, mesmo que fugazmente, de um caráter Humano, o que evidentemente soará sempre estranho a nós.

$\mathrm{O}$ dia em que o ser humano souber comportar-se à maneira dos fenômenos desprovidos de intenção - pois toda a intenção ao nível do ser humano obedece sempre à sua conservação, à sua duração - nesse dia, uma nova criatura pronunciaria a integridade da existência. (KLOSSOWSKI, 1972, p.198-199)

Podemos tomar como exemplo de escrita que se dá em e no processo, em uma fluxografia, um autor como o brasileiro José Agrippino de Paula. Em um livro como Lugar Público podemos pressentir esta escrita que se escreve por andamentos, que vai se desenhando dentro da própria produção do texto. As frases, os parágrafos e os capítulos são concebidos independente do que os antecede, além de recorrerem à repetição, como em um leitmotif de certos trechos. Os fatores de contiguidade com uma força do confessional e do onírico, na aproximação com os delírios e desatinos da desrazão - que será visitada no terceiro capítulo - cravam a condução irrefreável de acontecimentos em narrativas obtusas. Deste modo, o movimento e o ato da escrita se torna um persistente êxodo, uma peregrinação sem destino - algo que pode ser associado à ideia de nomadismo bastante trabalhada na filosofia contemporânea, principalmente a partir de Deleuze e Guattari. Um lugar público da literatura seria este espaço de livre circulação, onde não são 
necessárias condições prévias e preconcebidas para se escrever: local onde as coisas são postas em relação, onde a diferença pode ser produzida:

As frases que eu escrevo são de três tipos: uma que pretende dizer algo, outra que não pretende dizer e uma terceira que encobre o que deve ser dito. Gráficos cuja função é esclarecer tornam o entendimento mais obscuro. Procuro unir uma linha à outra, buscar alguma relação entre as setas e os números. (DE PAULA, 2004, p.224-225)

Assim como com a ideia de fronteira territorial, em um espaço, o tempo da passividade borra seus pontos referenciais, ele "exclui o 'sujeito' do presente e o presente do sujeito" (GARRIGUES, 1995, p.169, tradução nossa). Quando a presentificação passa a, não simplesmente deixar de existir, mas embaralhar suas coordenadas, uma suspensão do tempo cronológico e linear é operada. Nos escritos desta dada fluxografia a própria memória, o que faria referência a um passado, se confunde com outros tempos, impedindo a fixação e atestação de uma marcação temporal. Nesta passividade, as vontades do sujeito, de um ego, são suprimidas ou ao menos extremamente atenuadas, onde não se persegue nada, somente se retém o desejo de se manter passivo.

Um dos estímulos maiores para Blanchot quanto à passividade diz respeito ao livro Bartleby, o escriturário de Herman Melville. O pensador francês vê na persona de Bartleby uma espécie de corporificação da própria passividade, abrindo passagem para a dúvida, a suspensão da definição e do definitivo. Este aparentemente excêntrico escriturário não chega a se opor às tarefas de copiar ou ler os textos copiados, ele apenas diz a seu chefe que "preferiria não fazer". Não se trata aqui então de um puro niilismo, da dialética mergulhada no "nada de vontade" ao qual se refere Nietzsche (DELEUZE, 1976, p.145), mas sim de uma releitura, ou transvaloração, desta perspectiva; esta passividade é outra, ela é uma espécie de impostura afirmativa. Neste ponto ela se aproxima do eterno retorno de Nietzsche que "transmuda o negativo: faz do pesadelo algo leve, faz passar o negativo para o lado da afirmação, faz da negação um poder de afirmar" (ibid., p.71). Mas o que concerne esta afirmação? Trata-se de uma operação inumana, que não busca se impor, a não ser por uma suave negação que se dá por meio da linguagem, na ênfase que não se encontra no uso do negativo (o mero "não"), mas no uso do verbo "preferiria".

A declaração de Bartleby implica um desvio por constar como atitude inesperada e que desmonta, desarma, e abandona aquele que demanda, que clama por uma resposta ou reação. Assim como a personagem, a escrita no desastre, ao se ver na obrigação de se pronunciar - de dar significado à linguagem - opera de maneira a escapar de uma severa ordem. Escreve Blanchot (1980, p.52, tradução nossa): 
A passividade não consente, não recusa: nem sim, nem não, sem grado, só the conviria o ilimitado do neutro, a paciência fora do controle, que suporta o tempo sem resistir a ele. A condição passiva é uma incondição: é um incondicional que não tem nenhuma proteção como abrigo, que não espera nenhuma destruição, que está fora da submissão assim como sem iniciativa - com ela, nada começa...

A atividade mesmo da digitação, ação frenética em que se prima pela velocidade e por uma insensibilidade no que se registra - já que seu conteúdo na maioria das vezes pouco importa para o digitador - demonstra ainda mais essa postura quase inerte e destemida. Deleuze chega inclusive a produzir uma classificação esquizoanalítica a partir da personagem de Melville, identificando em Bartlebly e em outras de suas personagens uma sintomatologia criadora (DELEUZE, 1997, p.92), demonstrando suas forças de não-representação, de enigmas não-arbitrários. Diz Blanchot (ibid., p.219, tradução nossa):

Em Bartleby, o enigma vem da "pura" escrita que não pode ser nada mais que uma cópia (reescrita), da passividade na qual esta atividade desaparece e passa insensivelmente e repentinamente da passividade ordinária (a re-produção) ao para além de todo passivo (...) Preferiria não fazer. Esta frase na intimidade de nossas noites: a preferência negativa, a negação que apaga a preferência e se apaga nela, o neutro daquilo que não há a fazer, a retenção, a doçura que nós não podemos dizer obstinada e que destrona a obstinação com essas poucas palavras; a linguagem se cala se perpetuando.

A passividade surge por meio de uma intuição que a pressente, que a coloca em trânsito, segundo Pierre Garrigues (1995, p.177, tradução nossa):

Blanchot define esta intuição, de forma explícita, em função de três recusas já evocadas: recusa do sujeito, pois "'eu' morro antes de ter nascido", recusa do talento pois "o dom de escrever é precisamente aquele que recusa a escrita", e a recusa do saber como saber de alguma coisa, aquele que falha em toda aproximação conceitual (pois ele vai ao impensável).

Estas três formas de recusa apontadas por Garrigues, reafirmam a vontade de supressão ou apagamento do sujeito, em direção à uma voz da indeterminação que será a do neutro; o afastamento da ideia de gênio inspirado ou ser dotado de talento para escrever; e ainda o distanciamento da noção de conhecimento, que nos aproxima da estranheza na apreensão e recepção de um conceito.

A passividade está ligada evidentemente a uma ideia de negação, a um "cruzar de braços", mas que, no entanto, nunca chegam a se cruzar; se há alguma forma de agressividade neste movimento ele se dá apenas pela mera ausência de atuação, ação ou reação. Talvez sua 
agressividade, sua força de recusa esteja na relação que guarda, inclusive semanticamente, com a ideia de paixão. Uma paixão passiva - nada mais paradoxal, posto que a paixão é aquilo que nos inquieta, nos transtorna, nos faz agir impensadamente, irracionalmente. Através de um belo jogo de palavras realizado por Blanchot, Peter Pál Pelbart especula a construção da passividade:

A passividade não apenas se subtrai à linguagem que a trai, ela também a mina. (...) "passivité, passion, passé, pas". O pas é recusa e passo, negativo e marcha. O passé é o passado imemorial que retorna, dispersando presente e futuro. A passion é o estar fora de si. E a passivité é tudo isso, inquietude febril, que no ruminar do imemorial recusa o ser e vai mais além, ou mais aquém dele. (PELBART, 2009, p.73)

Vemos assim como a passividade pode ser portadora de uma intensidade latente e, quando confrontada com nossos modos cotidianos e rotineiros de percepção, desestrutura certezas, objetivos e finalidades.

\section{Silêneio}

"As palavras que trazem a tempestade são as mais silenciosas."

F. Nietzsche

Pelo desastre, Blanchot traz à tona um silêncio bastante peculiar, um silêncio como que primitivo e ao mesmo tempo por vir pertencente a cada palavra. Esta sua leitura é mais uma que nos apresenta de maneira bastante desafiadora. Como pensar uma escrita do silêncio? É possível exprimi-lo em linguagem? Quando o silêncio se revela, a literatura necessariamente deixa de existir?

O silêncio talvez seja uma palavra, uma palavra paradoxal, o mutismo da palavra (conforme o jogo da etimologia), mas nós bem sentimos que ele passa pelo grito, o grito sem voz, que contrasta com toda palavra, que não se dirige a ninguém e que ninguém recolhe, o grito que tomba em berro. $\mathrm{O}$ grito, como a escrita (do mesmo modo que o vivo que sempre já excedeu a vida), tende a exceder toda linguagem, mesmo se ele não se deixa retomar como efeito de língua, uma vez que súbito (submetido) e paciente, a paciência do grito, que não pára no não-senso, tudo restando fora do sentido, um sentido infinitamente suspendido, descrito, decifrávelindecifrável. (BLANCHOT, 1980, p.86, tradução nossa)

Através deste trecho podemos arriscar que uma das maneiras de se vislumbrar o silêncio na escrita seja através da ultrapassagem frente à linguagem, que, mesmo tendo as palavras como fonte, 
possamos como que esgotá-la em sua vontade referencial, significadora, devolvendo-a a sua condição de preexistência (parece-nos o caso, por exemplo, de um livro como Cap au Pire de Samuel Beckett e de outras de suas produções). A noção de primitivo aqui se insere no modo como este silêncio já parece constar em toda palavra, como que escondido em cada uma delas - em um local próprio onde mascara em si uma "palavra muda" - um grito que empurra a linguagem para fora dos códigos de significação, deixando exposta a ausência de uma dita clareza ou coerência. É nesta direção que afirma Deleuze (2005, p.141):

Esta língua moderna que escava uma "língua estranha em sua língua" e, através de um número ilimitado de construções gramaticais superpostas, tende a uma expressão atípica, agramatical, como que visando ao fim da linguagem (...) E o finito-ilimitado, ou a superdobra, não é o que Nietzsche já delineava sob o nome de eterno retorno?

Novamente a relação com o eterno retorno de Nietzsche se faz presente, pois do mesmo modo, o silêncio aparece como agente provocador de fascínio, de uma quase hipnose. Seguindo a trilha do enigma, que parece unir os elos da cadeia de elementos do desastre, o silêncio seria mais um sintoma de um amargo desejo, da vontade de alcançar o inalcançável, o impossível: "O silêncio é impossível. Eis por que nós o desejamos" (BLANCHOT, 1980, p.23). Ele se espreita em uma escrita do inapreensível, aquela que mesmo em mutismo escreve, se anuncia, já que este silêncio da palavra se coloca em posição de necessidade, exigência. O silêncio se performatiza na escrita como um vulto transparente, que só poderá ser trazido à superfície do texto e da página quando o autor se retirar, dando-lhe alguma possibilidade de voz, no esgotamento da significação e no retorno da palavra a sua morada silenciosa, livre do senso e do não-senso. Sabemos o quão estranho isto pode soar, mas esta é a questão: à escrita do desastre cabe conviver e incorporar a aporia, o impasse.

No rastro do desastre, o silêncio visa a eternidade para além da (de)marcação da linguagem, aquela que se instaurava em um tempo histórico identificável, fixo. Com ele, o pensamento de Blanchot se alça a mais um grau de ruptura, arrancando do texto literário outra de suas certezas pretensamente inabaláveis, a do discurso. Como extrair o silêncio da linguagem? Como levar a escrita ao ponto no qual ela mesmo se cala, ou melhor, se silencia?

Desde que o silêncio iminente do desastre imemorial o fizera, anônimo e sem mim, se perder na outra noite onde precisamente a noite opressora, vazia, para sempre dispersada, despedaçada, estrangeira, o separava e o separava para que a relação com o outro o assediasse com sua ausência, com seu infinito longínquo, era necessário que a paixão da paciência, a passividade de um tempo sem presente ausente, a ausência de tempo - fosse sua única identidade, restrita a uma singularidade temporária. (BLANCHOT, 1980, p.29, tradução nossa) 
Pierre Garrigues afirma que a fala fragmentária visa "tornar o silêncio expressivo" (GARRIGUES, 1995, p.135, tradução nossa) - entretanto nos parece que este silêncio do desastre só atinge alguma expressividade por meio de uma expressão muda, esgotada, não intencional. Garrigues aponta também para o fragmento que almeja "não esquecer do valor quase musical do silêncio: sua descontinuidade contribui também para marcar um certo ritmo" (ibid., p.134, tradução nossa). Neste caso, o autor de Poetiques du fragment se refere às lacunas, os vãos que resultam das separações entre os blocos textuais. Acreditamos que o silêncio do desastre atua de outra forma. $\mathrm{Na}$ perspectiva de Garrigues, este silêncio se faz manifesto, se torna presentificação, o que, para nós, eliminaria a força do silêncio tal qual exposto por Blanchot. Para o pensador francês, o silêncio é algo que rodeia, espanta, assusta a linguagem Humana, e é por esta assombração que ele se expõe. Não se trata de colocar o silêncio em prática, mas sim de saber que, ao lidarmos com as palavras, ele sempre estará à espreita.

O artista e compositor John Cage realizou em 1952 uma peça chamada 4'33" (ou "quatro minutos e meio de silêncio”), que constava na execução de uma música composta apenas por silêncio. Ao expor ou "executar" este silêncio frente a um público, Cage desnudava a própria linguagem e os signos musicais (a partitura, com suas notações, indicações de ritmo, pausa, intensidade etc.). Esta forma de esvaziamento da linguagem, ou exposição de uma existência prévia às construções do artista, é talvez próxima ao que Blanchot sugere quando trabalha o silêncio, na ausência e mesmo na presença da palavra literária e/ou filosófica: que saibamos, ao escrever, que ele está sempre presente - para além de significações previstas, dos sentidos que damos às palavras -, que tenhamos a noção de que ele pode esconder algo insuspeito. O filósofo francês nos leva de encontro à pergunta: o que pode haver de anterior, de primitivo, aos sentidos que já estão dados?

O que então, aparentemente, seria arma letal, de destruição em massa para a escrita acaba a alimentando. No silêncio, onde há a ausência da linguagem puramente nomeadora, o desastre se faz pressentido. É assim que Blanchot reafirma que toda palavra sofre o assombro do silêncio.

Apreender o silêncio. O silêncio não se apreende, ele não diz respeito à obra que pretende o apreender - ele é a exigência de uma espera que não espera nada, de uma linguagem que, supondo-se totalidade de discurso, se gastaria em um só golpe, se desuniria, se fragmentaria sem fim. (BLANCHOT, 1980, p.51, tradução nossa)

Liquefazendo uma retórica na escrita - força própria ao fragmento -, a constante vontade significante e indicial das palavras também é desfeita, abrindo caminho para uma falta ou uma devolução à palavra: o silêncio. O esgotamento da linguagem, um tipo de abertura para o silêncio blanchotiano, nos faz perguntar: o que dizer depois que tudo já foi dito? Talvez a resposta seja justamente essa: ele, o silêncio, deixar que ele fale, que se faça presente através da espessura 
translúcida que lhe é própria. "Deixemos ao silêncio esta frase que não quer talvez dizer senão o silêncio” (BLANCHOT, 1980, p.208).

\section{Neutro}

Abrimos este elemento tão instigante dentro da conceitualização de uma escrita do desastre, com uma citação indagativa do próprio Blanchot (2010, p.36):

"O neutro: o que entender por essa palavra?" - "Talvez não haja então nada a entender." - "Sendo assim, excluir de início as formas sob as quais, pela tradição, somos mais tentados a aproximarmo-nos dele: objetividade de um conhecimento; homogeneidade de um meio; intercâmbio de elementos; ou ainda, indiferença fundamental, ali onde a ausência de fundo e a ausência de diferença caminham juntas." - "Nesse caso, onde estaria o ponto de aplicação de tal palavra?"

Entrometendo-nos neste monólogo plural do pensador francês (onde aspas e travessões se fazem presentes, como falas, pronunciamentos) diríamos, de saída, que o neutro está sob o cuidado da pura indeterminação, ele é figura oscilante que não se deixa apreender como voz de gênero ou categoria (nem homem nem mulher, nem presente nem onisciente), ocupante de uma posição entre o visível e o invisível. A chave parece estar novamente não em margens aparentemente opostas, mas em um entre. O neutro é impessoal, portador de vozes cambiantes e anônimas, onde não encontramos uma pessoa. Isto ${ }^{16}$

é aquilo que não se distribui em nenhum gênero: o não geral, o não genérico, assim como o não particular. Ele recusa a pertença tanto à categoria do objeto quanto à do sujeito. E isso não quer dizer apenas que ele ainda está indeterminado e como que hesitando entre os dois, isso quer dizer que ele supõe uma outra relação, que não depende nem das condições objetivas, nem das disposições subjetivas. (ibid., p.30)

Como de praxe, Blanchot executa mais um nó no pensamento ao dizer mais adiante:

(...) digamos que seria neutro aquele que não intervém naquilo que diz; assim como poderia ser tida por neutra a fala, quando se pronuncia sem levar em conta aquele que a pronuncia ou sem levar-se a si própria a conta, como se, ao falar, ela não falasse, deixando falar aquilo que não se pode dizer naquilo que há para dizer. (BLANCHOT, 2010, p.36)

A partir destas frases nos perguntamos (dentre muitas possibilidades): como é possível não

\footnotetext{
${ }^{16}$ Utilizamos a expressão indicativa "isto" para nos referir ao neutro com o intuito de escapar de qualquer tipo de definição pronominal, aproximando-nos assim do que será brevemente especulado adiante, a partir de Clarice Lispector. Nas citações optamos por não alterar a tradução dos livros de Blanchot já publicados.
} 
intervir naquilo que nós mesmos dizemos, ou que pensamos dizer? Como anunciar, emitir uma fala, uma escrita na qual não nos colocamos? Dizer sem se dizer, ou dizer sem dizer a si, ou de si. Esta fala evidentemente busca se afastar de um "eu” enunciativo/enunciador, do sujeito que se mostra já de antemão na escrita. Primeiras, segundas ou terceiras pessoas não são encontradas, não há um pronome firmador. Enraizados que estamos em uma tradição literária, esta ideia novamente soa como uma afronta, como mais "uma ameaça e um escândalo para o pensamento" (ibid., p.30).

O neutro é um conceito bastante resgatado em Blanchot quando a literatura aparece de maneira a subverter e desfazer a presença de uma voz narrativa, ou até de um autor, que anuncia uma história, um discurso. Mesmo quando essa voz narrativa se apresenta de forma clara, óbvia ${ }^{17}$, durante o texto ela parece renunciar a sua condição de protagonista para trazer à tona, e colocar em posição de destaque, outro aspecto de estranhamento, da ordem do irreconhecível. Escreve-se, anuncia-se, de uma fonte emissora desconhecida. Peter Pál Pelbart indica esta condição do neutro que tem o autor em processo de desaparecimento:

Como se o pensamento também fosse chamado a cavar em si uma região de refluxo, inabitada e inabitável, uma zona de cegueira e de impossibilidade, de interrupção, a fim de que algo pudesse advir. O mesmo diz respeito ao autor: é preciso que ele se retire, enquanto sujeito, é preciso que ele desapareça enquanto eu, para que advenha a literatura no seu livre jogo, na sua exterioridade própria e pura. (QUEIROZ et al., 2007, p.65)

Neste afastamento do sujeito, de um “eu”, Pierre Garrigues cita Cioran, um dos escritores que identifica como transmissor de uma poética do fragmento, que diz que "a escrita não é expressão, mas expressividade" (apud GARRIGUES, 1995, p.190, tradução nossa). Este ser que escreve busca se apagar em texto, não mais apenas "se expressar", mas atuar diversamente por meio de uma performance sem rosto, na dissolução de suas feições. Este escritor é aquele que escreve “(...) não para refugiar-se no abrigo de uma subjetividade 'autêntica', mas para dissolvê-la" (PELBART, 2009, p.82). Uma voz que vem de um local indiscernível - essa voz "vinda de outro lugar" - que alterna sua existência entre a possibilidade de ser e não-ser. Para Blanchot, esta escrita exerce um movimento em que o próprio “narrar põe em jogo o neutro" (BLANCHOT, 2010, p.147). Para além da narrativa há de se ressaltar a figura do autor que incessantemente se perde e se retira.

A voz narrativa carrega o neutro. Carrega-o na medida em que: 1) falar no neutro é falar à distância, reservando essa distância, sem mediação nem comunidade, e

\footnotetext{
${ }^{17}$ Pensamos sobretudo no exemplo do livro L'arrêt de mort (traduzido malogradamente como Pena de Morte no Brasil) de Blanchot. Neste livro um narrador que identificamos como um homem descreve uma condição de enfermidade de uma personagem feminina com quem ele se relaciona, porém sem contato efetivo ou afetivo. Entretanto, essas personagens não são plenamente definidas, nem tampouco a situação, assim como a iminente morte da personagem todos os eventos parecem ficar em suspenso.
} 
mesmo experimentando o distanciamento infinito da distância em que rege a dissimetria, sem que um ou outro dos termos seja privilegiado, é precisamente o neutro (não se pode neutralizar o neutro); 2) a fala neutra não revela nem esconde. Isso não quer dizer que ela nada signifique (pretendendo abdicar do sentido sob a forma do não sentido), isso quer dizer que não significa do modo como significa o visível-invisível, mas que abre na linguagem um poder outro, estranho ao poder de aclaração (ou de obscurecimento), de compreensão (ou de mal-entendido). Ela não significa à maneira ótica; ela se mantém fora da referência luz-sombra que parece ser a referência última de todo conhecimento e comunicação a ponto de fazer-nos esquecer que ela só tem o valor de uma metáfora venerável, isto é, inveterada; 3 ) a exigência do neutro tende a suspender a estrutura atributiva da linguagem, essa relação ao ser, implícita ou explícita, que, em nossas línguas, coloca-se imediatamente tão logo alguma coisa é dita. (BLANCHOT, 2010, p.150-151)

Estas duas condições de afastamento - a do autor e a da voz narrativa - não resultam pura e simplesmente (erro que podemos incorrer no perigo de uma primeira e alvoroçada leitura) em uma mera aproximação com o não-senso (o dito "non sense"), mas sim em um caminho de transitoriedade, que abre frestas para a diferença. Esta é tornada condição possível pois um "eu" desejoso de significado não se faz mais presente. Isto leva também, e consequentemente, a uma perda, a um afastamento da noção de obra, já que para esta existir, um criador, um autor é necessário. Desindividualizar, despessoalizar a escrita, a literatura, é uma das condições para que o jogo do neutro aconteça. No neutro, o narrador ou o autor, busca se esquivar, se esconder, ocupar posição de desfoque.

Perguntamo-nos então: mas por que isso? E Blanchot parece responder (tendo como aliados autores que vão de Franz Kafka e Samuel Beckett a Marguerite Duras e René Char): pois só assim as palavras, a linguagem e o texto podem ganhar seus próprios contornos, impondo discretamente suas condições. É através dessas condições que talvez se torne viável a experiência do neutro, que é passagem de hesitação, enigma e dúvida - ligações, operações conectoras do desastre. Resta-nos finalmente realizar a pergunta que o pensador francês resgata de um dos poemas de René Char: “Como viver sem ter diante de si o desconhecido?”. Pergunta motriz que não visa uma resposta, mas que é carregada como instigadora e propulsora das criações artísticas.

Em um mesmo rastro efetivado pelo neutro blanchotiano, com algumas formas de mutações, mas ainda como que relacionáveis, podemos localizar outros agentes de indeterminação que circulam próximos de sua orbita. Três casos em específico nos chamam a atenção: na literatura, com a partícula "it" de Clarice Lispector; na filosofia, com o ser qualquer de Giorgio Agamben; e em um sentido político de cyber-ativismo, com o movimento anonymous. No livro Água Viva, Clarice Lispector menciona um "mistério impessoal" incorporado pela partícula, proveniente do inglês, "it". A escritora afirma que esta partícula age de alguma maneira em todas as coisas do universo (em um humano, em uma ostra...), na forma de uma energia do desconhecido que pode incorporar em tudo, 
se transformando quase em matéria orgânica. Já o ser qualquer de Agamben não respeita seu sentido e forma recorrentes, de nomeação de um qualquer, de um indiferente; ele escapa ao pertencimento a um grupo, classe ou gênero, colocando sua força em uma vontade (na quebra da palavra qual-quer) que não fala "em nome de", mas que anuncia por pura necessidade potencializadora. No terceiro caso, a atuação do movimento anonymous caracterizada por ataques hackers sobretudo à instituições financeiras e de controle e espionagem - de grandes bancos internacionais à CIA e o FBI - é realizada sempre através da utilização desta identidade desconhecida, que visa diluir o sujeito para dificultar sua identificação e consequente penalização, além de possibilitar a coexistência de ataques múltiplos de uma só face indeterminada que aponta de diversos locais: persona inexistente, máscara que pode ser vestida por quem bem quiser.

Ao neutro está também ligada mais diretamente a noção da morte na escrita - espelhada na morte do autor, do sujeito. Para que este tipo de desaparecimento ocorra “... seria preciso ser o sujeito livre e falante e desaparecer como o paciente-passivo que atravessa o morrer e que não se mostra" (BLANCHOT, 1980, p.38, tradução nossa). O que interessa ao pensador francês quanto à morte, dentre outros fatores, é essa condição de incorporação, novamente, do inalcançável, do intangível. Por isso é que ela está tão próxima do desastre, e é o que parece ligar todos seus elementos. Uma equação blanchotiana: desejar escrever = desejar morrer. Mas aqui, novamente, trata-se de um olhar diverso sobre a morte, pois como diz Blanchot (2007, p.153): "Sempre foi tarefa da cultura dar à morte uma espécie de pureza: torná-la autêntica, pessoal, própria ou ainda torná-la possível”. A morte para o pensador francês é a impossibilidade de morrer. Em um movimento diverso deste da cultura, ele não busca transportá-la ao possível, ao inteligível ou ao sensível, mas à própria condição de ausência, da falta onde ela só pode se fazer pressentida.

\section{Esquecintento}

Blanchot evidencia, em $L^{\prime}$ Écriture du Désastre, uma valorização do ato de esquecer. Para ele, este processo aproximaria o texto de uma singularidade ingênua, inédita, que tem sua repetição próxima a um eterno retorno. Para o escritor, esquecer seria o primeiro ato em direção à escrita do desastre, pois este movimento lhe garantiria uma espécie de limpidez não-viciada, pois passa a escrever a partir do que na verdade não tem plena ciência, algo que o assegura a capacidade de se livrar de referências preestabelecidas - e é por isso que o desastre não figura em um estilo, uma estética ou método aplicável -, ele só é possível quando se esquece, o que não é evidentemente de caráter racional. 
O esquecimento: não presença, não ausência.

Acolher o esquecimento como o acordo com aquilo que se oculta. $\mathrm{O}$ esquecimento, em cada acontecimento que se esquece, é o acontecimento do esquecimento. Esquecer uma palavra é encontrar a possibilidade de que toda a fala seja esquecida, estar próximo da fala como se estivesse esquecida e também próximo ao esquecimento como fala. $\mathrm{O}$ esquecimento ergue a linguagem em seu conjunto reunindo-a em torno da palavra esquecida.

No esquecimento, há o que se desvia de nós e há esse desvio que vem do esquecimento. Relação entre o desvio da fala e o desvio do esquecimento. Daí que uma fala, mesmo dizendo a coisa esquecida, não falte ao esquecimento, fale em favor do esquecimento. (BLANCHOT, 2007, p.171)

Nota-se como dizer o esquecimento - algo aparentemente absurdo - seria uma ação inconsciente, como se a fala e o próprio esquecimento firmassem um acordo secreto, silencioso, do qual o escritor não teria acesso ou conhecimento, mas que fizesse parte e colocasse em prática sua vigência:

O desastre, preocupação do ínfimo, soberania do acidental. Isto nos faz reconhecer que o esquecimento não é negativo ou que o negativo não vem após a afirmação (afirmação negada), mas está em relação com o que há de mais antigo, o que viria do fundo das eras sem jamais ter sido dado (BLANCHOT, 1980, p.11, tradução nossa)

No esquecimento, o tempo enquanto acontecimento é personagem protagonista para a tentativa de compreensão deste processo de história à deriva, suspensa, não localizada em memorialismos e nostalgias. Nietzsche já havia alertado para a potência do esquecimento, e esta é a trilha que Blanchot parece seguir e continuar a abrir caminho. O filósofo alemão afirma que é através do esquecimento, na supressão de uma memória reativa e niilista, demasiada humana, histórica, que se pode atravessar, ultrapassar, e enfim esquecer de uma vez por todas a má consciência e o ressentimento ${ }^{18}$. O escritor, o filósofo se esquece, é quando se põe enfím a inventar.

Blanchot reserva ao esquecimento um valor de tempo imemorial, do qual nada se pode guardar, e no qual estamos prostrados em posição de passividade, em uma permanente espera sem intencionalidade. O neutro do tempo seria um acontecimento que se dá fora da história, nãohistórico, esquecido, para além da categorização temporal, a santíssima trindade do tempo: passadopresente-futuro. Desastre: um contra-tempo (não-cronológico, e da aporia):

(...) o esquecimento, nem negativo nem positivo, seria a exigência passiva que não acolhe nem retira o passado, mas, designando nele aquilo que jamais teve lugar (como no por vir aquilo que não saberá encontrar seu lugar num presente), reenvia

\footnotetext{
${ }^{18}$ Estamos cientes do imenso esclarecimento que estes termos podem suscitar, porém nos interessa aqui, ao tratar de Blanchot especificamente, apenas esta fuga do memorialismo humano. Para maiores aprofundamentos e elucidações sugerimos cf. Nietzsche e a filosofia de Gilles Deleuze.
} 
a formas não históricas do tempo, ao outro dos tempos, a sua indecisão eterna ou eternamente provisória, sem destino, sem presença. (BLANCHOT, 1980, p.134135)

Escrever memórias somente se posicionados na incerteza de acontecimentos ocorridos e/ou ficcionalizados, ou ainda, como se contando memórias ainda por vir, intuídas. O caráter essencialmente fragmentário das lembranças - elas são, é evidente, seletivas e reconstruídas - as torna também fala do fragmento, escrita particionada.

Um dado interessante é que um suposto foco de atração do esquecimento reside no fato de algumas coisas só se darem a partir dele. Por exemplo, no próprio passar das horas cronológico. Quando estamos insistentemente atentos ao relógio, consultando-o impacientemente em intervalos curtos, as horas se arrastam; quando paramos de verificar os ponteiros a todo instante, ou seja, quando deixamos o horário recair no esquecimento, o tempo passa - os alarmes e os sinos soam - e nos surpreendemos, admirados pelo fato dele ter se dado tão rápido. Parece ser assim também com a palavra. Poder esquecer o que ela diz, ao que faz referência, ou mesmo não lembrar do que se quer utilizar como vocabulário, possibilita uma reencarnação à linguagem, sua chance surpreendente. Escrever pelo esquecimento é, portanto, tarefa crucial na busca por uma escrita do desastre.

A relação entre memória e esquecimento no desastre não se dá simplesmente no dado de que uma é mera sombra da outra, forças que podem e devem se eclipsar. Não se trata aqui de um encerramento, negação ou anulação. Há inclusive uma espécie de memória própria ao esquecimento, que seria a lembrança de uma preexistência que remete a um tempo imemorial, a alguma espécie de instinto extinto no ser/escritor (e no silêncio de cada palavra, sem dúvida). Este ato da escrita nos força ao esquecimento.

Escreve-se e muitas vezes se esquece, é recorrente para aquele que escreve a pergunta: Como fiz isso? Fui eu realmente quem escreveu? Assim, o esquecimento tem firmada a sua importância por se perpetuar, sem se fazer consciente, marcando o fim das expectativas memorialistas e possibilitando ainda um desvio, abertura para um devir. Sua base está também na ideia de que, com a supressão de um "eu”, com o erigir de um "impessoal”, neutro, o esquecimento passa a subsistir de forma diversa, não dependendo de uma memória para retornar, e deixar de ser o ou um esquecido. A leitura de Blanchot é a de que o esquecimento é na verdade: "pensamento, quer dizer, aquilo que não saberia ser esquecido porque sempre já quedado fora da memória" (BLANCHOT, 1980, p.49, tradução nossa). O pensador francês evidencia assim como a força do esquecimento está muito mais na relação que pode travar com o pensamento, e não com a memória, que é o que busca aniquilá-lo, desfazê-lo; já no pensamento ele não pára de agir, de forma inconsciente, mas sempre atuando em um avanço sem quedas enfraquecedoras (biografismos, 
aspectos estritamente pessoais etc.).

Podemos citar como exemplo de livro de resgate de uma memória que não possui feitios puramente nostálgicos e biográficos, o Minha vida da escritora norte-americana Lyn Hejinian. Seu jogo com a linguagem, uma experimentação quase laboratorial, marcado por reiterações e repetições de frases durante os 44 fragmentos do livro, remontam a cada ano da vida da autora até o ano de sua publicação. Talvez seus fragmentos-idades façam referência mais ao esquecimento de que fala Blanchot do que à própria memória de sua vida. As imagens que marcam suas lembranças de infância, de juventude e da vida adulta entram neste processo da escrita que tudo diferencia, liberando-a da memória individual, de uma pessoa. O tempo mesmo passa a embaralhar-se, não seguindo evidentemente qualquer preceito cronológico. É no trabalho incessante e meticuloso com a linguagem, deixando ela despejar seus efeitos, que esta dissolução da memória parece ocorrer.

Escrever de, inscrever-se em um tempo imemorial livra o escritor de uma mera descrição de eventos passados, abrindo caminhos para tempos da impessoalidade (daí uma aproximação em cadeia com o neutro), e liberando-o para um "presente sem memória que é o da palavra narrante" (BLANCHOT, 2010, p.148), enfim "é a narrativa, independente de seu conteúdo, que é esquecimento, de modo que narrar é pôr-se à prova desse esquecimento primeiro que precede, funda e arruína toda memória" (ibid., p.148). Esta é finalmente a errância de tempos imemoriais onde a escrita se costura, se perfaz:

o esquecimento: o movimento de esquecer: o infinito que se abre, fechando-se com o esquecimento - na condição de acolhê-lo, não pela ligeireza que libera a memória da memória, mas na própria lembrança, como a relação com aquilo que se esconde e que nenhuma presença saberia reter. (BLANCHOT, 2007, p.170)

\section{Vigílita}

"O dia demora a chegar, há um intenso eclipse solar."

Fausto Fawcett

Da vigília se pode dizer que é um instante delirante - um sonho sem sono. Àquele que permanece em vigília não é oferecida a opção de descanso. Para Blanchot, a imagem do ser neste estado estaria ligada à maneira como o escritor - o do desastre - operaria: "O escritor, o insone do dia” (BLANCHOT, 1980, p.185). Este ser-artista está sempre em eterna vigília, sob a observação e o acompanhar de sua própria criação, fabricação. Mesmo quando não está efetivamente escrevendo, há sempre algo em ocorrência, processando matéria que pode vir a se tornar literária. Quando mergulhado na escrita, se encontra em um mundo “(...) em que se vai e vem sem nada agarrar e, no 
entanto, abismo em que o repentino decide..." (BLANCHOT, 2007, p.168). Este estado do desastre é mais um que se prima pelo incontrolável e incontornável.

$\mathrm{Na}$ persistência desta condição, o protoautor (dadas as suas condições de neutralidade e passividade) de uma escrita do desastre se mantém em um estado de constante "Fazer vigília sobre o sentido ausente" (BLANCHOT, 1980, p.72). A vigília é mais um componente que dialoga com a noção do eterno retorno de Nietzsche, pois marca este dia, este tempo, sem início nem fim, dado a um círculo vicioso de insônia criadora sem sujeito, sem vontade - pura necessidade -, o neutro nunca dorme.

Outro aspecto que pode ser relacionado com a vigília (bem como com os outros elementos do desastre) é a ideia de paciência. A paciência do desastre é aquela que se relaciona intimamente com uma espera - uma espera doce, passiva. Sem prazo ou deadline, tal qual a vigília, neste aguardo não é possível situar instantes. Esta espera pode tomar corpo inclusive no processo do pensar, Blanchot chega a afirmar que o pensamento é justamente a paciência do corpo (ibid., p.77), tanto quanto na escrita - por meio de um texto que não sabe o que espera, e espera sem expectativa. É através de um repouso silencioso que ocorrem as mediações de breves falas, diálogos enigmáticos:

- É preciso portanto esperar ainda. Enquanto se espera, o que há a se fazer? Que fazemos?

- Bem, enquanto se espera, conversemos.

- Sim, conversamos, escutando a voz. Mas que voz é essa?

- Não algo para se ouvir, talvez o último grito escrito, aquilo que se inscreve no futuro fora do livro, fora da linguagem.

- Mas que voz é essa? (BLANCHOT, 2010, p.72)

Mas nessa paciência da escrita, do pensamento, o que exatamente se espera?

A conversa acima citada, bem como esta indagação anterior, nos faz recordar Godot, o personagem existente-inexistente beckettiano. As personagens Vladimir e Estragon não sabem por que esperam, nem até quando - apenas acreditam se tratar de uma suposta vinda de Godot. Vivem em um limbo de repetições, em uma expectativa que nunca se realiza. Nesta peça, que contém indícios indeléveis do desastre, tudo entra em suspenso, o tempo precisamente. O conselho, a indicação: "seja paciente", não pode ser aplicada no caso da paciência tal qual Blanchot a aborda, visto que nesse caso não é possível decidir por ser paciente (de onde provém um paciente-passivo), não há escolha, esta condição não parte de uma atitude, mas simplesmente de um acontecimento, de uma experiência na qual nos vemos engendrados sem controle. Não seria assim também com a escrita? Só nesta espera será possível que "Partilhemos a eternidade para torná-la transitória" (BLANCHOT, 1980, p.220). 
Vela-se por algo que não se pode identificar, e quando identificável não se pode confirmar a aparição. Viver em uma perpétua "noite em claro" - daí a imagem do escritor como o insone do dia -, é nesta condição que o escritor do desastre se desencontra. Clarice Lispector chegou a afirmar: "Verifico que escrevo como se estivesse entre o sono e a vigília" (LISPECTOR, 1973, p.55). A operação de um estado onírico também se faz presente na vigília, pois mesmo no sono, o insone do dia não pode descansar, não conseguindo identificar um estado próprio: sonhar acordado, estar em um entre, em um entrelaçamento, é sua única possibilidade, o que o aproxima do delírio, e de uma forma de alucinação:

Do sonho, não saberíamos nos lembrar; se ele vem a nós - mas de qual vinda? Através de qual noite? -, não é senão pelo esquecimento, um esquecimento que não é somente de censura ou de recalque. Sonhando sem memória, de uma maneira tal que todo sonho temporário seria um fragmento de resposta a um morrer imemorial, riscado pela repetição do desejo.

Não há cessação, não há interrupção entre sonho e despertar. Nesse sentido, é possível dizer: jamais, sonhador, você não pode despertar (nem, ao resto, te deixar assim chamar, interpelar). (BLANCHOT, 1980, p.61)

O desastre blanchotiano é esta vigília que não se pode abandonar. A noite seria o período no qual tudo parece descansar, silenciar-se, mas que, no entanto, não deixa de existir e colocar acontecimentos em operação. Isto infere em um embaralhamento, em uma simbiose entre processos, períodos de um dia. Mesmo quando estamos dormindo o mundo do pensamento - e de certa forma o da escrita - continua a se desenrolar, apesar de termos às vezes a impressão de que tudo se submete ao apertar de uma tecla pause, tornando-se inerte, para só retomar suas ações ao acordarmos. Esta é, entretanto, uma visão necessariamente subjetiva, presa ainda ao "eu" (visão não partilhada pelo desastre): "a vigília é descobrir que vida e morte estão necessariamente ligadas, enquanto os homens adormecidos continuam a viver-e-morrer uma falsa aparência de vida mantida" (BLANCHOT, 2007, p.13). 


\section{$\underline{\text { 2.3 }}$ Três cenas primitivas a partir de Hiroshima mon amour}

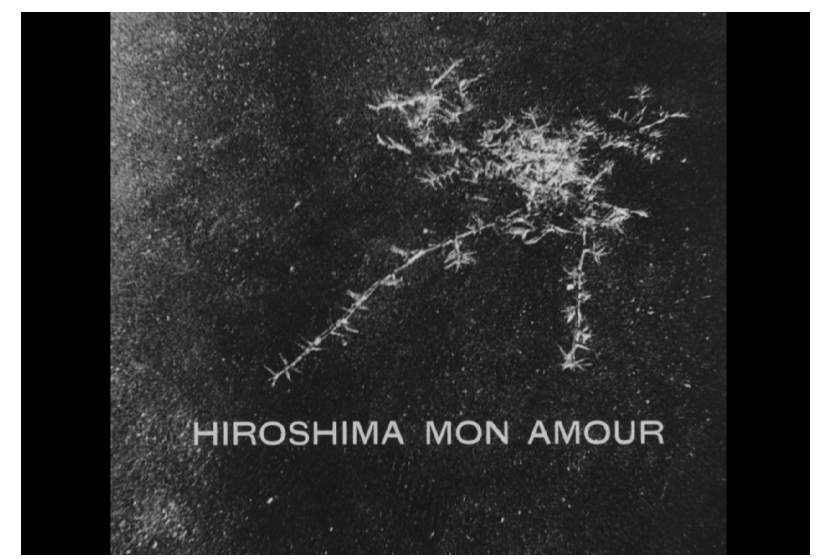

"Não tenho simpatia pela bomba. Observo que ela só é um signo, um signo grosseiro, do extremo perigo que marca necessariamente a passagem de um tempo a outro e talvez da história a uma época trans-histórica.”

Maurice Blanchot

Se o perigo do desastre está em lhe atribuir sentido ao invés de corpo, parece-nos plausível tentar observar como operam seus elementos em uma peça artística que se localiza em um dado período histórico marcado, mas que aponta para indícios de escape a ele. Encontramos no filme Hiroshima mon amour (1959) de Alain Resnais, a presença destes elementos, sempre sob a iminente vigilância do desastre, que parece pairar pelos fotogramas de sua película. Além disto, este filme atravessa dois campos de extrema importância quando temos o desastre blanchotiano em questão: a história e a literatura. Ele está inserido no contexto da segunda guerra mundial, e na hesitação e impossibilidade da relação entre uma atriz francesa e um arquiteto japonês, que se conhecem na cidade de Hiroshima, anos após o bombardeio nuclear de 1945. O filme possui ainda uma íntima ligação com a literatura, pois seu roteiro foi escrito por Marguerite Duras, tendo sido posteriormente publicado em forma de livro. Seu texto é todo composto em forma de diálogo, sendo que toda a enunciação se dá através das vozes dos dois protagonistas, em instantes que correm a esmo, em um curto período de tempo que recorrentemente escapa de sua cronologia. Cabe dizer que o desastre dito "literal" de Hiroshima - aquele que está ao lado da catástrofe, da barbárie, a própria explosão da bomba e seus efeitos - não se furta ao desastre blanchotiano, apesar de nem sempre ser de sua alçada (as forças humanistas que podem residir neste desastre literal, não se encontram na perspectiva de Blanchot, por exemplo). 
Em L'Écriture du Désastre, Blanchot inicia três blocos, ou fragmentos, com a expressão (entre parênteses) "uma cena primitiva". Perguntamo-nos: mas o que seria exatamente uma cena primitiva? Quase automaticamente responderíamos que seria um acontecimento que remete a um passado que de tão distante parece já não nos pertencer, se deslocando de nossa própria experiência, de nosso tempo, do tempo mesmo da civilização. Ao nos referirmos a uma cena está implícita a presença de uma atuação, de uma sequência gestual, de ações inseridas em um cenário específico, com suas peculiaridades - paisagem, luz, composição. Ao primitivo podem ser associadas atitudes guiadas pelo instinto, livres da mediação controladora da razão.

O primitivo tem uma relação evidente (inclusive etimologicamente) com a ideia de mito. Aqui, se apresenta um forte elo de ligação entre os três autores mais colocados em evidência até agora nesta pesquisa, já que tanto F. Schlegel, como Nietzsche e Blanchot valorizaram e trabalharam com a mitologia: o primeiro, ao suscitar a necessidade da criação de uma nova mitologia a partir dos ideais românticos de fusão entre poesia e filosofia; o segundo, na construção e exposição de seu pensamento através do personagem Zaratustra (que possuía uma relação bastante próxima com o deus Dionysos); e o terceiro, na possibilidade de criação, de invenção gerada no estreitamento cada vez maior entre as noções de ficção e de teoria, na composição de uma "teoria fictícia", onde o mito continua a ser aquilo que surge para explicar o inexplicável.

A partir de Nietzsche a ideia das novas mitologias ganha força crucial, principalmente por delas poderem se inaugurar pensamentos dotados da genealogia. De acordo com Jean-Luc Nancy (1999, p.114, tradução nossa): “O mito é de origem e da origem, ele faz referência a uma fundação mítica, e por essa referência ele funda a si mesmo (uma consciência, um povo, um relato)". Blanchot talvez tenha visto nesta perspectiva a chance de fundar mitos estranhos, trans-históricos pois como diz Nancy (ibid., p.245) a história é a forma moderna do mito - provenientes de inconsciências, que resgatam uma força primitiva, pré-pessoal ou individual, envoltos pelo "pensamento de uma ficção fundadora, ou de uma fundação pela ficção" (ibid., p.134, tradução nossa). A mitologia fundada a partir do século XX talvez seja esta que veremos com Blanchot, da cena de uma criança que fixa seu olhar profundamente através de uma janela.

Veremos a seguir como em trechos destes três blocos de cenas primitivas criados pelo pensador francês são imprimidas variações intensas entre teoria, ficção e crítica, o que abre a possibilidade da relação com aspectos do filme de Resnais e Duras e com os elementos componentes do desastre. O pensador francês parece criar suas imagens, ou cenas, na tentativa de capturar, materializar algo do desastre, e é nesta materialização de sua alquimia que se encontra também Hiroshima mon amour. 


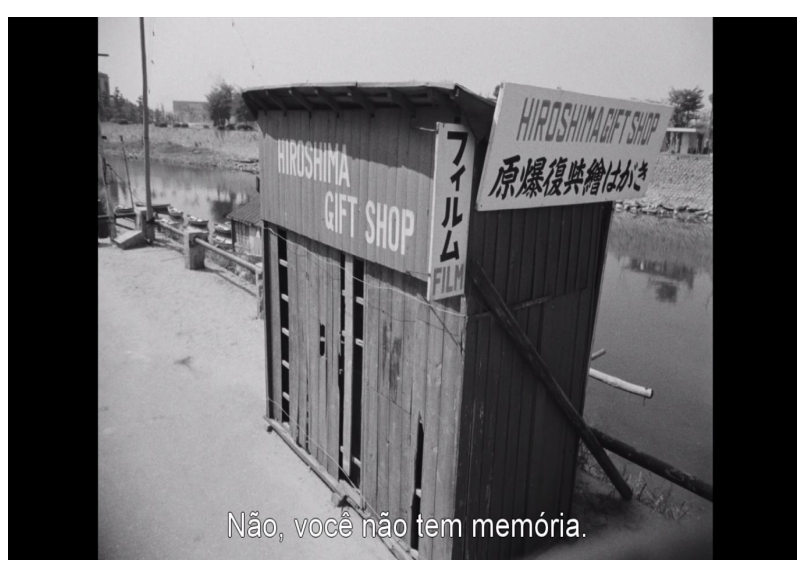

(Uma cena primitiva?) Vocês que vivem mais tarde, próximos de um coração que não bate mais, suponham, suponham-no: a criança - tem ela sete, oito anos talvez? - de pé, afastando a cortina e, através da vidraça, olhando. O que ela vê, o jardim, as árvores de inverno, o muro de uma casa: enquanto ela vê, sem dúvida à maneira de uma criança, seu espaço de jogo, ela se cansa e lentamente olha para o alto em direção ao céu ordinário, com as nuvens, a luz cinza, o dia pálido e sem profundidade.

O que se passa em seguida: o céu, o mesmo céu, repentinamente aberto, negro absolutamente e vazio absolutamente, revelando (como que pela vidraça quebrada) uma tal ausência que tudo nela desde sempre e para sempre se perdeu, a ponto que nela se afirme e se dissipe o saber vertiginoso de que nada é aquilo que há, e de saída nada para-além. O inesperado desta cena (seu traço interminável), é o sentimento de felicidade que logo submerge a criança, a alegria devastadora a qual ela não poderá testemunhar senão pelas lágrimas, um escoamento sem fim de lágrimas. Crê-se numa tristeza de criança, procura-se consolá-la. Ela não diz nada. Ela viverá doravante em segredo. Ela não chorará mais. (BLANCHOT, 1980, p.117)

Esta descrição de uma cena em que uma criança - portadora de toda uma inocência e de um olhar ainda não viciado pela vida e pelas experiências adquiridas - observa uma paisagem através da janela de casa, faz sobressaltar uma espécie de catarse, a invasão de um sentimento que evidentemente não saberia explicar (sem dúvida as palavras mais atrapalhariam do que ajudariam), cuja única expressão material, matéria líquida, se dá através de lágrimas silenciosas não compreendidas por adultos, que tentariam a consolar, ligando a expressão à óbvia reação de tristeza, sem que na verdade a criança precise de qualquer consolação. Quando crescemos, carregamos este tipo de esquecimento, de uma lembrança esquecida, de um tempo imemorial como prefere Blanchot, que nos marca fortemente, e que é como "a ruminação do desastre" (GARRIGUES, 1995, p.60, tradução nossa). É inevitável, ao ler e pensar esta cena, não lembrar da busca por um tempo perdido empreendida por Marcel Proust. Esta busca impossível, de um tempo que já se deu, acaba 
por tomar corpo apenas na forma de uma escrita da ficção da memória - se bastando nesta insuficiência e em um falso contrato com a realidade, com a veracidade - pouco importando a carga de fidelidade do relato.

Em Hiroshima mon amour a atriz francesa interpretada por Emmanuele Riva realiza no transcorrer do filme uma série de referências a seu passado, de tenra juventude, vivida na pequena cidade de Nevers, ocupada então pelo exército nazista. Ela carrega traumas, dos quais parece hesitar alternando entre o esquecimento e a possibilidade de vivenciar ainda uma felicidade, um segundo amor sempre confundido com o primeiro (seria o amor sempre o mesmo?). Este amor de juventude diz respeito à relação que teve com um soldado alemão combatente do partido nazista, morto assim que a ocupação alemã na França fora desfeita. Estes pontos marcam e influenciam sua maneira de existir no presente, configurando uma confusão entre tempos, resgatado principalmente pela recorrência do amor impossível. Seus atos de aparentar distanciamento e insensibilidade são claramente influenciados por aqueles eventos da juventude - o estado de loucura e isolamento a que foi submetida após a morte de seu namorado -, como se fosse dali catapultada repentinamente para aquele momento passado, e tudo voltasse com o fim do esquecimento que garantia a vida, um seguir em frente, mergulhada no "estado de arrebatamento em que se esquece tudo" (BLANCHOT, 2013, p.19). Era neste esquecimento que a atriz parecia garantir ainda algum vitalismo, alguma alegria, apontando para outro caminho de vida que não uma pura e simples sobrevivência, um vagar reativo. No ato de rememoração sua força é fortemente atenuada, e por isso ela parece tanto se debater, soar enfraquecida antes e durante a lembrança do passado.

Assim como a criança de Blanchot - que ao observar a suposta mudança do céu por meio da vidraça (mas o que realmente teria mudado; o céu - o mesmo céu cinza -, ou o olhar e o sentir do pequeno?) vislumbramos em um flashback do filme, a jovem que, sentindo-se invadida por um sentimento inexplicável, percebe-se de alguma maneira livre da loucura (torna-se novamente “razoável", na palavra de seus pais), devido a um simples e breve instante permeado também pelo olhar: pega com as mãos e admira uma bola de gude que deslizara da rua para dentro da adega/porão na qual estava em estado de clausura e isolamento. O tempo passado nesta condição, um tempo dado à eternidade, enfim se rompe, posto que a eternidade no desastre é uma eternidade que - de maneira incompreensível - consegue se tornar transitória. 


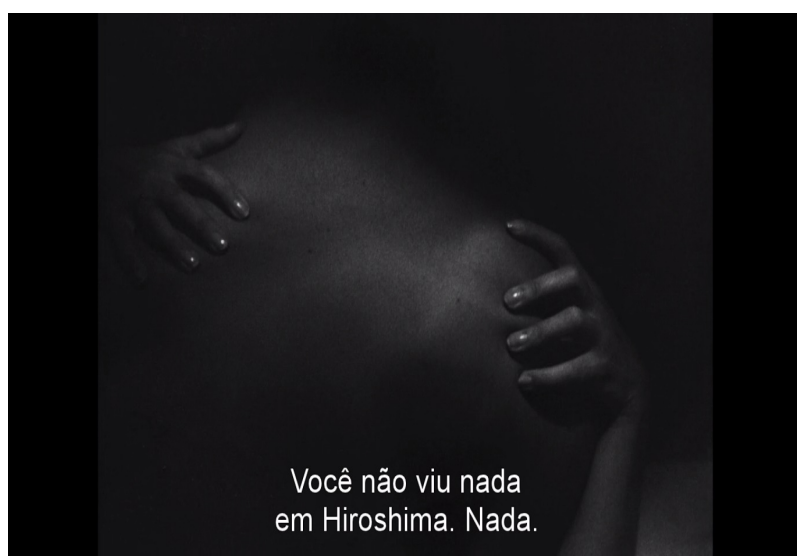

(Uma cena primitiva?) "Indiscrição, indizivel, infinito, mudança radical, não há entre o que se chama por essas palavras, senão uma relação, ao menos uma exigência de estranheza que as torna turno a turno - ou em conjunto - aplicáveis ao que foi nomeado como uma cena? - Erroneamente, pois escapando ao figurável, como à ficção; simplesmente para não falar assim de um acontecimento que teve lugar em um dado momento do tempo. - Uma cena: uma sombra, um fraco luar, um "quase" com os traços do "demasiado", do excessivo em tudo, - $O$ segredo ao qual se fez alusão, é que não há nada de secreto, exceto para àqueles que se recusam à confissão. (...) - Eu o concedo: "nada é o que há" proibido de se deixar dizer em tranquila e simples negação (como se em seu lugar o eterno tradutor escrevesse: "Não há nada"). - Nenhuma negação, mas termos que pesam, posições justapostas (sem vizinhança), suficientemente fechadas (fora da significação), cada um imóvel e mudo, e assim usurpando a sua ligação em frase o que ela apenas pode conter brilhando. - Da minha parte, ouço o irrevogável do há que ser e nada, marulho vão, projetando, reprojetando, traçando, apagando, ondulando segundo o ritmo do anônimo ruído. - Ouvir o sem-eco da voz: estranho entendimento. - Entendimento do estranho, mas não avancemos muito mais. - Já tendo estado muito à frente, voltando. - Voltando em direção à interpelação inicial que convida à suposição fictícia sem a qual falar da criança que jamais falou, seria fazer passar na história, na experiência ou o real ainda, a título de episódio ou de novo de cena imóvel, o que os arruinou (história, experiência, real) os deixando intactos. - $O$ efeito generoso do desastre. - A senescência do rosto sem rugas. - O insulto maior da poesia e da filosofia indistintas".

"A questão sempre suspensa: estando morta do "poder-morrer" que lhe dá alegria e devastação, teria ela sobrevivido, ou antes, o que quer dizer sobreviver, senão viver de uma aquiescência à recusa, no ressecamento da comoção, em retração do interessamento por si, des-interessado, extenuado até a calma, nada esperando? - Por conseguinte, esperando e mantendo vigília, pois repentinamente despertado e, sabendo doravante, jamais suficientemente despertado." (BLANCHOT, 1980, p.176-179, tradução nossa)

Este trecho traz o especular da ideia de cena, em um trabalho de força teórica, mas que não se deixa furtar à criação de imagens. Um acontecimento: algo que muda o curso e o estado das coisas. Mas uma das peculiaridades do desastre é a capacidade de tudo transtornar, deixando tudo intacto (ibid., p.7). Esta característica mostra como o desastre penetra em níveis mais profundos, 
deixando a superfície das coisas em um estado aparentemente ordinário, o que de alguma forma oculta seus efeitos, não os deixando capturar pela clareza ou por empirismos.

A atriz do filme de Resnais e Duras não esteve em Hiroshima na época do bombardeio, porém o contexto na qual se insere a faz confundir a tal ponto suas certezas que ela passa a acreditar que realmente viu e vivenciou aquilo tudo, e até que ponto poderíamos dizer que ela não esteve lá, já que vivenciou eventos diretamente ligados ao ocorrido? A ficção se sobressai assim perante o real, sendo ambas construções possíveis.

$\mathrm{Na}$ primeira sequência do filme, a voz do ator Eiji Okada parece encarnar uma voz do desastre. Ele pressiona esta voz repetitivamente junto à negação, em direção ao esquecimento e ao neutro (não sabemos ainda quem é este personagem, e mesmo depois nos perguntamos: ele fala por si? Pelo outro? Por ninguém?), duvidando de qualquer mínima certeza de realidade, do ocorrido sentido pela atriz. “- Você não viu nada”. As falas são entremeadas por saltos, fragmentariamente enunciadas, no desmembramento de um discurso, de uma narrativa que pudesse ser plenamente apreendida.

A atriz passa a citar supostos fatos concretos que pudessem asseverar a sua condição de testemunha real do acidente de Hiroshima: objetos, fotos, explicações, reconstituições, tudo quanto fosse possível transformar em memória, o que não quer deixar cair no esquecimento. O museu que ela diz ter visitado, localizado ao lado de seu hotel (o "Nova Hiroshima") e o motivo pelo qual está na cidade - a gravação de um filme - buscam reconstituir os eventos, as cenas que se deram após o bombardeio de 1945 com a intenção de manifestar repúdio à barbárie humana, além de reforçar os pedidos pela paz mundial. Por estar participando diretamente deste cenário, e pelo contexto de seu presente, para a atriz é como se ela realmente estivesse visto/vendo tudo in loco. Ocorre a partir daí uma espécie de criação de um duplo da mulher, que aparecerá com maior nitidez na sequência do espelho, mencionada adiante.

O "poder-morrer" mencionado por Blanchot - esta opção dada apenas pelo desastre - é a possibilidade de atingir a força de uma morte, mas ainda sim continuar vivo (como a protofórmula "Escrever: recusar escrever (...) como se o obrigássemos a sobreviver, a se prestar à vida para continuar a morrer. Escrever defeituosamente. [BLANCHOT, 1980, p.22, tradução nossa]), poder morrer e ainda sim sobreviver, alterado por um estado subterrâneo, rasteiro. "Não podemos nada dizer além do morrer; mas a morte é viver. O desastre não é a inércia; ele designa algo aqui ou acolá, que o dizer não pode dizer, mas que a ausência é um modelo de presença" (GARRIGUES, 1995, p.56, tradução nossa). É esta morte que é experienciada pela criança que olha pela janela na primeira cena primitiva e agora pela atriz. Um trecho de L'Écriture du Désastre parece dizer diretamente da posição da atriz de Hiroshima mon amour: 
Morrer quer dizer: morto, tu já o és, num passado imemorial, de uma morte que não foi a tua, que tu, portanto, não conheceste nem viveste, mas sob a ameaça da qual tu te crês chamado a viver, esperando-a doravante do porvir, construindo um porvir para torná-la enfim possível, como alguma coisa que terá lugar e pertencerá à experiência. (BLANCHOT, 1980, p.108)

Blanchot realiza uma analogia desta morte, que não é efetivamente experimentada pelo ser, mas que acaba incorporada à experiência de uma vida, com o próprio ato de escrever (que da mesma maneira poderia ser transportado ao ato fílmico):

Escrever não é mais pôr no futuro a morte sempre já passada, mas aceitar sofrê-la sem torná-la presente e sem se tornar presente para ela, saber que ela teve lugar, ainda que não tenha sido provada, e reconhecê-la no esquecimento que deixa e cujos traços que se apagam, chamam a se excetuar da ordem cósmica, lá onde o desastre torna o real impossível e o desejo indesejável. (ibid., p.108-109, tradução nossa)

Os movimentos descontínuos de encontro e desencontro entre a atriz e seu amor japonês, enquanto vagam em vigília pela cidade silenciosa entregue a um pretenso descanso da noite, marcam um estado de indecisão e a tentativa de estender algo daquela jornada. Reencontrar o amor sob o signo do desastre de Hiroshima é reencontrar o fim da guerra que lhe tirou seu primeiro namorado. O que resta aos amantes é entrelaçar ao máximo seus corpos, salpicados por um brilho, iluminados e acetinados pelo suor - início ou fim?

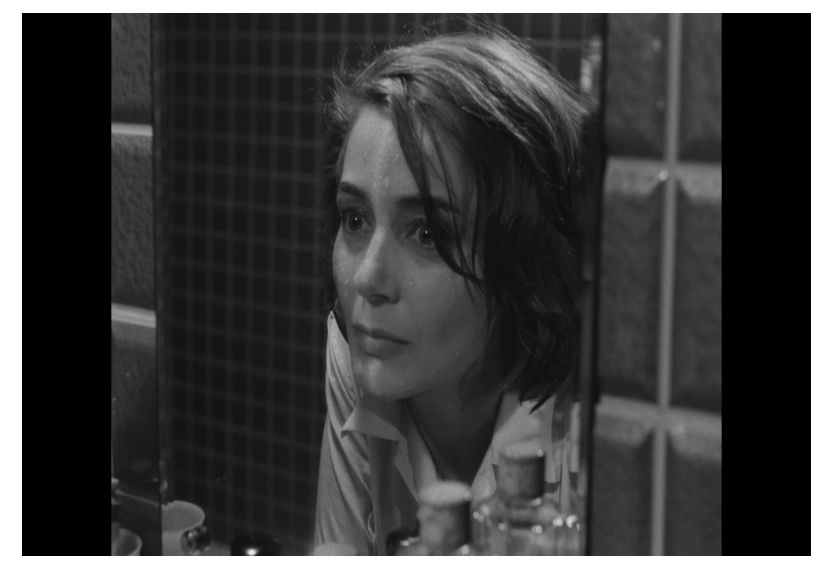


(Uma cena primitiva?) (...) O que há de mítico neste mito: a morte está nele presente quase sem se nomear, pela água, a fonte, o jogo floral de um encantamento límpido que não abre sobre o sem-fundo apavorante do subterrâneo, mas que o mira perigosamente (loucamente) na ilusão de uma proximidade de superfície. Narciso morre? Quase; tornado imagem, ele se dissolve na dissolução imóvel do imaginário onde ele se dilui sem saber, perdendo uma vida que não há; porque, se podemos reter alguma coisa dos antigos comentadores, sempre prontos a racionalizar, é que Narciso jamais começou a viver, criança-deus (a história de Narciso, não esqueçamos, é a história dos deuses ou semi-deuses), não se deixando tocar pelos outros, não falando, não sabendo, já que, segundo a ordem que ele recebera, ele deve permanecer desviado de si - assim, bem próximo da criança maravilhosa, sempre já morta e entretanto destinada a um morrer frágil, do qual Serge Leclaire nos falou. (...) e sina também dos apaixonados que se tocam pelas palavras, que estão em contato por palavras e assim podem se repetir sem fim, se maravilhar com o mais banal, justamente porque sua língua é língua, e não linguagem, e que eles se miram um no outro, pela reduplicação que vai da miragem à admiração. (BLANCHOT, 1980, p.191;193;195, tradução nossa)

As feições, as expressões faciais, os rostos dos amantes estarrecidos não cansam de questionar suas situações, sempre em constante iminência fantasmática, de algo que já ocorreu. Sua incredulidade está tanto em saber o que se deu quanto em como será possível seguir em frente. O absurdo causado pela barbárie se aproxima da ficção e se ressignifica pela dúvida: não é possível ter certeza, e isto não impedirá o testemunho. A atrocidade os paralisa sem conseguir, entretanto, os deixar totalmente estáticos. O efeito anestesiador que acomete os amantes é um efeito que não lesa, não os deixa catatônicos, e se o faz, é somente por conta de um êxtase. Os diálogos silenciosos mantidos pelos amantes que se olham sem fundo e sem fim, são como diálogos libertos da linguagem, o que garante um desencontro com vícios ocasionados pela força da necessidade de significados, de sentidos figurativos, e é isso que talvez faz com que o mais banal possa se tornar maravilhoso.

O mito de Narciso retomado por Blanchot se aproxima da condição da atriz em Hiroshima mon amour pela força impressa e pela importância da imagem. A cena em que se olha fixamente no espelho, conversando com seu próprio reflexo, com um outro indiscernível, evidencia o contraste entre o mergulho na superfície, do rio, do espelho, e na profundidade de si. Um estranhamento certamente sentido pela atriz se deu no passado pelo fato de que - em oposição ao resto do mundo que se encontrava em estado moribundo, de extrema tensão e holocausto - no tempo de guerra, da ocupação nazista em sua terra, ela foi feliz, pois foi quando pôde conhecer e vivenciar pela primeira vez o amor. Blanchot recria e remete constantemente à incredulidade que as imagens de algumas paisagens podem incorporar - um deserto, um céu sem estrelas -, e esta talvez seja uma tentativa de expor esta condição impossível, imperceptível do desastre, e dos seres que por ele são atravessados. 
Através do mito, torna-se novamente possível tentar explicar o inexplicável - no caso da atriz de Hiroshima mon amour este sentir avesso ao resto do mundo.

A sequência na qual Emmanuele Riva se mira no espelho é composta por um diálogo consigo mesma, ou na verdade, com um duplo provocador, aquele que só ganha voz a partir do retorno da memória, de trágicos souvenirs, provenientes da lembrança do amor perdido na guerra (o amor alemão), e do atual que continua de alguma maneira a habitar este contexto (o amor japonês). Durante sua conversa na casa de chá, enquanto conta sua história para o arquiteto, os amores passam a se equivaler, a ponto do próprio japonês falar do alemão em primeira pessoa, como se estivesse ele a encarnar o amor primeiro. Trata-se afinal do mesmo fardo: o mito do amor impossível assombrado pela guerra. 


$$
\begin{aligned}
& 6 \\
& 5 \\
& 5
\end{aligned}
$$

3

\section{Terceiro Capítulo \\ [ A Comunidade da Desrazão ]}

6
5 


\title{
3.1 Diluindo a história: sobre crises e comunidades
}

\begin{abstract}
"Dir-se-ia que alguma coisa se passa entre eles, com velocidades e intensidades diferentes, que não está nem em uns nem nos outros, mas realmente no espaço ideal que já não faz parte da história, e tampouco é um diálogo de mortos, mas uma conversa interstelar (...)".
\end{abstract}

Gilles Deleuze

Os eventos ocorridos na cidade de Hiroshima e a declaração do fim da segunda guerra podem ser identificados como causadores de uma fissura, recortando quase que ao meio o século XX e influenciando diretamente a forma como a partir de então todo o mundo se postaria diante desta nova condição pós-guerra e pós-barbárie atômica, alterando drasticamente os movimentos na história, na cultura e nas artes.

Após as duas primeiras grandes guerras, a inauguração do abalo nuclear ocorrido em Hiroshima, e a última grande dicotomia marcada pela guerra fria que opunha os EUA e a URSS, o mundo passou a não ser mais apenas assombrado por conflitos entre polos ou lados opostos, entre nações, mas a enfrentar também guerras - talvez neste caso seja mais pertinente o uso da palavra crises - dos mais diversos caracteres. Apesar da persistência de algumas reações desejosas da manutenção de um status quo que ainda visa perpetuar maniqueísmos em lutas que incidem na colisão entre um lado que representa "o bem" e outro que representa "o mal" (o cinema hollywoodiano - a exemplo da nação norte-americana, não perdeu e continua a se alimentar de antigos vícios), está claro que algo mudou. Mesmo quando uma disputa parece ser entre dois lados claramente definidos e opostos, esta se passa em um ambiente diferenciado (um exemplo disto são os conflitos que se dão na internet, no virtual, em chamadas ciberguerras onde os hackers são os novos soldados, combatentes).

Na passagem pós década de 80 há a aparição constante de crises locais, como as guerras civis diárias, pretensamente escondidas (na verdade concentradas e acossadas nas periferias) nos grandes centros urbanos. Além destes conflitos pertencentes às ordens do dia das cidades, temos também aqueles de contornos globais, fruto de um desenvolvimento humano sempre agressor, mesmo quando se propondo sustentável: nota-se que a tentativa é sempre a de, no máximo, atenuar os irreversíveis danos. Estas crises se apresentam sobretudo nas formas ambientais, biológicas e epidêmicas. Não há como negar o fato plenamente possível - já apontado por diversos pensadores, teóricos, políticos etc. - de estarmos já vivenciando uma guerra em andamento, mas que acaba dissolvendo sua plena identificação na medida em que ataca por diversas vias, e das formas mais diluídas - em um permanente, discreto e urgente estado de sítio. É como se a humanidade estivesse 
se acostumado com antigas condições e hábitos, não conseguindo observar o grau de dano que causou, está causando e que ainda pode causar.

Podemos identificar aqui a passagem para uma era pós-atômica, não no sentido de uma ultrapassagem do iminente perigo nuclear, já que continuamos sob a vigilância deste desastre -, mas sim na condição atual em volta a numerosas ameaças, permeadas pelo sentimento de que não há apenas um grande conflito vigente.

O fato de L'Écriture du Désastre ter sido publicado no ano de 1980, o primeiro de uma década que viveu sob a constante ameaça de uma terceira guerra mundial, permeada pela polaridade EUA x URSS e pela recomposição de uma série de Estados-nações antes colonizados e atravessando guerras civis (na América do Sul de Brasil, Argentina, Chile etc., e na África das recém independentes Angola, Moçambique etc.) é certamente ponto a ser destacado. Neste livro se concentram - em blocos, fragmentos descontínuos - uma vontade (paciente e passiva, como vimos) de ruptura de dualismos, sempre apontando para uma multiplicidade, e para o fim da subjugação de um controle exercido na escrita por pontos referenciais e totalitários, dos domínios próprios ao discurso. Algo que certamente também foi importante para a concepção deste livro foi todo o percurso realizado por Maurice Blanchot, que tendo nascido no ano de 1907, acabou por participar e produzir praticamente durante todo o século XX (e em alguns momentos sendo presente ativista como no período de maio de 68 , e nos seus textos em revistas de caráter notadamente político como a Combat, na década de 40). Além disto, na literatura e na filosofia, o ano de 1980 situou interessantes lançamentos que coadunam com as perspectivas de estremecimento, de desastre, em conceitos os mais diversos e em experimentações como, por exemplo, no já citado Minha vida de Lyn Hejinian, em Totalidade e Infinito - Ensaio sobre a exterioridade de Emmanuel Lévinas (amigo desde a juventude, talvez o mais próximo de Blanchot) e Mil Platôs de Gilles Deleuze e Félix Guattari. Estas obras foram também componentes de rupturas com hegemonias consagradas, especializantes e uniformizadoras, através de uma potencialização na dissolução de fronteiras de definições generalizantes do saber.

L'Écriture du Désastre apontou também para um devir - sendo fiel ao seu caráter fragmentário, marcado sempre por desvios - realizado não só por meio de leituras (diretas e indiretas) do que ocorrera e estava ocorrendo no mundo e na literatura, mas apontando também para um descentramento que é característico dos tempos atuais, e como vimos, notadamente nas guerras, nas crises. Hoje, podemos identificar uma pluralidade nas formas de escrita e em seus meios de divulgação (identificada principalmente pela democratização, ainda em estado de estudo e observação, promovida pela internet), ao mesmo tempo em que persistem vontades homogeneizadoras cada vez maiores, tornadas possíveis ainda por uma indústria do consumo, do 
espetáculo e das celebridades (a literatura evidentemente não escaparia), dos bestsellers aos livros de autoajuda. Neste ponto a escrita do desastre pode ser identificada como uma escrita de resistência - mas uma forma de resistência diferente das ocorridas no passado: ela é subterrânea, vagarosa e quase oculta, não buscando mais a forma do manifesto (ato sedimentado pelas vanguardas modernistas). Um trecho de outro livro de Blanchot, A Conversa Infinita, apesar de ter sido publicado pela primeira vez na França no ano de 1969, parece estar dizendo já do início do século XXI:

Note-se bem que as contradições em que nos achamos, a infelicidade de um pensamento que não tem nada por onde começar e que se dissipa de um infinito ao outro, essa ambiguidade em que nos disseminamos, não permanecendo, indo e vindo sem cessar, sempre aqui e lá, e no entanto em parte alguma, curiosos a respeito de tudo a fim de não nos determos em nada, mundo em que nada está presente ou ausente, onde não há nem proximidade nem distância, onde tudo nos escapa deixando-nos a ilusão de tudo ter, é a consequência de uma obscuridade dispersa, difundida e como que errante, que não tivemos a força de fixar.

A diversão é esse jogo da luz equívoca.

Onde tudo é indeciso só se pode viver num desvio perpétuo... (BLANCHOT, 2007, p.28)

Esta última frase parece concentrar o que pode ser a literatura no contemporâneo. A indecisão, o vacilar recorrente, a dispersão em que nos pegamos em flagrante (dispersão que valoriza a ambiguidade tão cara a esta palavra, e que aqui intentamos dizer mais no sentido de estar disperso, sem concentração, alheio) só pode ser ultrapassada por meandros de incorporações, desvios, ou tentativas de: hoje tudo é possível - a ideia de que os acessos estão facilitados - ao mesmo tempo em que nada é possível - a sensação de que tudo já foi esteticamente realizado, e de que a arte está esgotada em um sentido negativo, rebaixado, niilista.

Como vimos, o desastre blanchotiano não se deixa pensar. Algumas experiências realizadas na literatura a partir da segunda metade do século XX (como as do grupo francês OuLiPo ${ }^{19}$ ), e principalmente a dita "escrita não-criativa" (do inglês uncreative writing) praticada a partir do início do século XXI por escritores como o estadunidense Kenneth Goldsmith, e que tem no ambiente virtual da internet importante e singular local de divulgação e propagação ${ }^{20}$, apontam para este espaço de indiscernibilidade entre senso e não-senso, coerência e incoerência, utilidade e inutilidade, criação e transcrição.

Uma parte da literatura brasileira da década de $80 \mathrm{em}$ diante, e ao falarmos de um processo que se deu no Brasil acreditamos que seja também uma fala extensiva ao âmbito internacional, - já

\footnotetext{
${ }^{19}$ OuLiPo (Ouvroir de Littérature Potentielle) - grupo de experimentos em escrito, espécie de laboratório matemáticoliterário, formado por escritores como Georges Perèc e Raymond Queneau.

${ }^{20}$ Indicamos a consulta da seminal base de dados de arte fundada por Goldsmith: a $u b u w e b$.
} 
que cada vez mais vemos nacionalismos sendo eclipsados e substituídos por uma ideia sempre global de mundo, de miscigenações e cosmopolitismos os mais variados - se configurou por um afastamento cada vez maior das vanguardas, de escolas como o surrealismo e o concretismo a recortes geracionais como na poesia do Brasil da "geração de 45" (tendo aqui uma relação com o recorte histórico promovido pelo fim da segunda guerra). Identificam-se as décadas de 60 e 70 como fundamentais para tais movimentos, da poesia de Torquato Neto e Waly Salomão, sob signo da Tropicália, à prosa de José Agrippino de Paula e Renato Pompeu. Estes autores nos transportaram e nos aproximaram de uma noção como a de "pós-moderno", sendo um dos processos desencadeados pós década de 70 o de misturar, confundir e diluir cada vez mais conceitos de forma e conteúdo como poesia, prosa, ensaio, crítica, desejando assim um distanciamento de vontades inclusivas e nomeadores de grupos e movimentos.

Por sua vez, estas literaturas já começaram a dar pistas também de uma transformação em curso, que não se limitava mais a uma definição como a de "pós-modernidade". As reverberações de uma cyberliteratura, que se deixa contaminar pelas novas formas virtuais de relação e mediação pelo maquinário, e de como estas transformaram a própria produção da escrita - além de passar a ser veiculada, na publicação e divulgação de formatos digitais - podem ser observadas em livros como Favelost: (the book) de Fausto Fawcett, e Todos os Cachorros são Azuis de Rodrigo de Souza Leão. Estes escritos estão em consonância com uma forma de transformação elementar - na escrita -, através de estímulos de tempos históricos e não históricos, sendo a cria de "poderes impessoais, representados pela intervenção nos fenômenos de massa, pela supremacia do jogo maquinal, e em terceiro lugar, pela apreensão das forças constitutivas da matéria” (BLANCHOT, 2007, p.275).

Maurice Blanchot se apresenta como pensador seminal do contemporâneo na medida em que suas conceitualizações abrem margens para processos que observamos nos tempos atuais, - a demarcação de territórios nômades, nas artes multilinguagem, de spoken words aos grafitis de intervenção urbana - manifestações estas que apresentam indícios do desastre, por meio, por exemplo, de uma mistura, do transtornar de ideias estabelecidas, e em uma ação catalisadora dos seus elementos. O pensador francês aponta direções para a relação que pode haver entre nossos tempos e a literatura, neste novo contexto de crises e conflitos, loucura e desrazão. Nos tempos do desastre a pergunta que paira é justamente: como conviver com a instabilidade, com a estranheza do que não dominamos e do que não podemos dominar?

Dos movimentos de transformação aderidos aos eventos disparados a partir do século XX e desaguados no contemporâneo, identificamos um que vai ao encontro com o pensamento de Maurice Blanchot e de outros autores. O erigir do conceito de comunidade, diálogo iniciado pelo filósofo Jean-Luc Nancy em La Communauté Descuvrée na primavera do ano de 1983, terá uma 
espécie de continuação (um processo próprio ao conceito) com Blanchot em $A$ Comunidade Inconfessável e posteriormente com Giorgio Agamben em A Comunidade que vem. Diferentemente da ideia de comunidade proposta e almejada pelos românticos alemães de Iena, que visavam uma vontade coletiva presente em tempo e espaço, dotada de ensejos ao mesmo tempo universais e locais, regionais, o conceito de comunidade trabalhado por estes três autores mencionados diz mais respeito a uma espécie de $\operatorname{amizade}^{21}$ não necessariamente presencial que se dá e é transmitida fraternalmente através do pensamento, de escritos, da literatura, da filosofia ou mesmo da arte. Nesta comunidade, a relação pode ser efetivada à distância, em separações de tempo e espaço de qualquer escala. Nietzsche chegou a pensar a força de um pensamento ou de uma obra de arte como o lançar de uma flecha (ou o próprio filósofo ou artista como catapultado pela natureza) que atinge no final das contas outros poucos seres, que poderão por sua vez reaproveitar, remodelar e relançar outras flechas. Nesta espécie de continuidade, que não necessita exatamente se fiar a uma noção de continuísmo, relações e conversas são traçadas podendo formar o que Jean-Luc Nancy chamaria de uma "comunidade do pensamento".

A natureza joga o filósofo como uma flecha no meio dos homens, ela não visa, mas espera que a flecha venha a se cravar em algum ponto. Fazendo isso, ela se engana um número infinito de vezes e fica exasperada com isso. (...) O artista e o filósofo testemunham contra o sentido prático da natureza na escolha de seus meios, ainda que estes sejam a mais excelente prova da sabedoria de seus fins. Eles só afetam poucas pessoas, quando deveriam afetar a todas, e mesmo estas poucas pessoas não são afetadas pela força que o filósofo e o artista deram a seu projétil.

(NIETZSCHE, 2003, p. 201)

Estas comunidades que almejamos reunir são, portanto, invisíveis e atemporais. Tal qual o desastre, suas presenças e seus encontros se dão por intuições, em um espaço virtual não-histórico ou trans-histórico - seria este o espaço do pensamento, onde se operam os conceitos e onde ocorrem as trocas entre artistas, filósofos e escritores? Talvez em um plano de imanência do qual falam Deleuze e Guattari? Diz Jean-Luc Nancy (1999, p.104, tradução nossa): “... textos intercalados, alternados, compartilhados, como todos os textos, oferecendo o que não pertence a ninguém e que retorna a todos: a comunidade da escrita, a escrita da comunidade”. Aqui, uma maneira de aproximação se dá na sensação de pertencimento, mesmo quando não há uma identificação clara ou uma vontade que caminhe neste sentido. O que faz com que dado autor escreva sobre ou a partir de outro? Para Nancy, tudo parte do conceito de desobramento proposto primeiramente por Blanchot:

A comunidade tem necessariamente lugar naquilo que Blanchot nomeou como

\footnotetext{
${ }^{21}$ Blanchot possui inclusive um livro fragmentário com o uso da palavra em seu título: L'Amitié.
} 
desobramento. Na obra ou para além dela, o que se retira da obra, o que não tem mais a ver nem com a produção, nem com a resolução, mas que encontra a interrupção, a fragmentação, o suspenso. (NANCY, 1999, p.78/79, tradução nossa)

Estas são ligações que passam pelo compartilhar do desencadeamento de paixões em comum, que não tratam de ou devem necessariamente e a todo instante concordar, mas que estão postas em conversa, em diálogo. Se é possível colocar autores dentro de uma ideia de comunidade, cremos ser também válido pensar que suas ideias, conceitos e proposições podem entrar em um movimento da construção de redes - noção bastante em voga no século XXI. Mesmo quando utilizando vocabulários, palavras e expressões diferentes, há a impressão de que falam, senão da mesma coisa, de coisas semelhantes ou próximas, de uma pulsão hereditária (tal qual mencionado, por exemplo, nos casos da aproximação entre conceitos de Nietzsche e Blanchot).

Dentro especificamente da literatura, Nancy relaciona esta comunhão da escrita e do pensamento com uma forma de "comunismo literário" que incide, como não poderia ser diferente, em uma nova leitura para o próprio marxismo. O que nos interessa aqui é como ele extrai dos conceitos de Marx e de releituras posteriores de sua obra (pois as flechas aqui também foram relançadas com o passar dos tempos) o que pode haver de mais fraterno no pensamento comunista, em sua verve afetiva, em que são valorizadas tanto a individualidade quanto a coletividade, mas só na medida em que ambas possam se alimentar mutuamente, em coexistência:

É por que há a comunidade - desobrada, sempre, e que resiste no seio de toda coletividade e no coração de todo indivíduo -, e é por que o mito se interrompe, suspendido, sempre, e dividido por sua própria enunciação - que há essa exigência: o "comunismo literário". Quer dizer: o pensamento, a prática de um compartilhamento de vozes, de uma articulação pela qual só há singularidade se exposta em comum, e só há comunidade se oferecida no limite das singularidades. (ibid., p.197, tradução nossa)

Assim como Blanchot - na esteira de F. Schlegel e Nietzsche - o autor de La Communauté Descuvrée evidencia um pensamento de torção, no qual o paradoxo age não para contrapor, mas para justapor ideias, perspectivas.

É curioso notar como nos tempos atuais vemos a aparição cada vez mais evidente da constituição, criação e organização de comunidades alternativas, por assim dizer, que buscam escapar de um sistema social urbano, e da própria ideia de sociedade construída principalmente a partir do final do século XVIII, do ideal iluminista e subsequentemente moderno. Estes grupos, conjuntos de con-vivência, surgem dos mais diversos campos de identificação: religioso, político, agrário, ambiental (e na maioria das vezes de mais de um destes ao mesmo tempo), mas 
transbordam estas fronteiras na busca por uma relação singular - e coletiva - com os seres e o meio que os circundam. Mesmo não fazendo exatamente parte principal integrante da fala de Nancy, da noção de comunidade que engendra, se torna oportuna a percepção de tal movimento, pois este também acaba por se coadunar com algumas de suas perspectivas, dizendo algo das lógicas internas de relação dentro das comunidades, algo que ainda está por ser plenamente identificado. Segundo Nancy (1999, p.30, tradução nossa) a comunidade

... não é somente constituída de uma justa distribuição de tarefas e de bens, nem de um feliz equilíbrio de forças e de autoridades, mas ela é feita antes de tudo do compartilhar e da difusão ou impregnação de uma identidade em uma pluralidade onde cada membro, por aí mesmo, não se identifica que pela mediação suplementar de sua identificação no corpo vivo da comunidade.

Tendo em mente então o conceito de comunidade proposto por Nancy, visualizamos a existência de um grupo de escritores dentro da literatura brasileira que configura uma espécie de comunidade da desrazão - capaz de realizar um desobramento, ato de fazer escapar, tornar visível algo dado ao invisível, colocar forças em operação por meio do fragmentar, criar a partir de uma ausência de obra útil, discursiva etc., através da desrazão. Estes autores possuíam quadros clínicos que foram identificados como pertencentes à loucura, o que gerou em todos eles a necessidade de internações - voluntárias e involuntárias - em hospitais psiquiátricos. Destas condições de isolamento, surgiram escritos que expõem de forma exemplar tanto as substâncias componentes de um corpo do desastre, quanto suscitam indagações referentes a diferenças e semelhanças entre a loucura e a desrazão, e o testemunho e a ficção. Em todos os casos a serem aqui estudados, as internações tinham o intuito de possibilitar a organização, a chance de "colocar as ideias no lugar", a tentativa de controle de atitudes extremadas. Surgem assim, pela perspectiva por nós adotada, duas vias para a ideia de comunidade: 1 - a comunidade forjada no internamento, da reunião de seres díspares que são considerados como uma só massa homogênea, reunião firmada no tempo e no espaço; 2 - o partilhar daquilo que não se pode dar ou receber, através de uma literatura catalisada pelo desatino e pelo delírio, a ideia de uma união das palavras da desrazão, dadas ao infinito.

Optamos por um recorte que - no movimento proposto dentro do pensamento de Blanchot e do desastre - iniciado no século XX alcançasse o século XXI, o contemporâneo. Estes escritores (alguns deles já previamente mencionados em algum momento deste estudo) são: Lima Barreto, Maura Lopes Cançado, Torquato Neto, Renato Pompeu e Rodrigo de Souza Leão. Não se trata, evidentemente, já que seria necessário um trabalho muito mais extenso para tal, de perpassar toda a bibliografia destes escritores, mas sim de salientar seus escritos frutos de internações, evidenciando 
aspectos próprios as poéticas de cada um, sendo consonantes ou dissonantes, e buscando visualizar como o espectro da desrazão se fez presente em parte da literatura brasileira, na construção desta comunidade. Em um primeiro momento, passaremos pelo processo de distinção entre loucura e desrazão, e da forma como - destes estados - algo producente, no caso a literatura, pode advir. Depois, visitaremos a ideia de testemunho na tentativa de compreender de que maneira o relato pode se misturar com a ficção, e o modo como cada um destes escritores transmitiu suas experiências de internação, na reconfiguração de aspectos autobiográficos transtornados que dialogam com a ideia de desastre por meio da escrita.

\subsection{Loucura e Desrazão: desvio e distinção}

Este subcapítulo surge da ânsia de realizar uma distinção bastante pertinente para compreender os escritos aos quais estamos dispostos a nos debruçar. O filósofo húngaro-brasileiro Peter Pál Pelbart realizou uma rica pesquisa na qual coloca em questão as confusões existentes entre as definições de loucura e desrazão, e este trabalho será fatalmente a maior fonte de apoio para nossas indagações neste terreno.

A primeira pergunta que para nós surge é: seria possível criar diante da loucura? De prontidão responderíamos que sim, pois temos inúmeros exemplos que nos fazem afirmar tal - Sade e Lautréamont seriam dois clássicos neste sentido, trabalhados inclusive por Blanchot. O que acontece é que a resposta a essa pergunta muda drasticamente quando levemente alterada a indagação: seria possível criar mergulhado na loucura? Aí diríamos que não, pois a loucura é total impossibilidade de produção, restrição geral do ser, estado em que ele já não consegue minimamente organizar seus pensamentos ou mesmo agir (o ato de empunhar uma caneta, ou o de levar os dedos às teclas de uma máquina de escrever ou computador se torna inviável). A loucura é o ultrapassar dos limites. Anteriormente, evidenciamos uma perspectiva da experiência-limite a qual nos leva a todo instante o desastre e seus elementos, condições em que nos encontramos em uma região fronteiriça, caminhando em uma corda bamba, mas que não chega a ser rompida. $O$ seu romper seria justamente a queda livre no abismo da loucura (ou da própria morte).

Indagamo-nos então o que seria este estar diante de que mesmo dado a um estado de loucura, em constante iminência, ainda consegue inventar, criar: é a desrazão.

Quando o pensamento e a escrita estão atuantes, a loucura se dilui - mesmo que temporariamente - para que um jogo dito desarrazoado emerja. Nos momentos em que uma carga, mesmo que mínima, de sobriedade advém é possível ao indivíduo concentrar energias para a 
produção de algo - no nosso foco de atenção - a literatura. Blanchot (2007, p.176) diz que no mundo da desrazão, “a loucura é apenas uma parte”. É quando uma espécie de campo magnético do delírio consegue ser absorvido e transmitido através da escrita que a desrazão encarna em uma matéria potencial para a literatura, pois dispara uma forma de apreensão de forças - de uma dada irresponsabilidade da ficção que entra em processo de simbiose com uma fidelidade ao registro, ao testemunho (fenômeno que investigaremos mais a fundo no subcapítulo a seguir) - como que colhidas da loucura. As forças do delírio são aquelas que colocam as coisas invisíveis para agir, cria do inexistente, e é o que os autores brasileiros aqui evidenciados realizaram.

Todos estes escritores em pauta escreveram sobre seus estados de delírio, e parecem a partir deles, no retorno desta profundidade, deste abismo no qual se corre o risco de permanentemente mergulhar, transportar as dadas experiências-limite. A desrazão funcionaria aqui como o estado que pode tornar produtora a loucura.

No direcionamento destes delírios para a escrita é natural que haja uma contaminação da própria linguagem. Nos versos de Torquato Neto, por exemplo, podemos pressentir ou mesmo sentir a intensa angustia e o espesso fel provenientes de seus espasmos suicidas, da dificuldade em se doar e desfrutar dos afetos do amor e da vida (sem mencionar o fato de todo o contexto sociopolítico brasileiro da época, em meio à ditadura militar):

\author{
Agora não se fala mais \\ toda palavra guarda uma cilada \\ e qualquer gesto é o fim \\ do seu início; \\ Agora não se fala nada \\ e tudo é transparente em cada forma \\ qualquer palavra é um gesto \\ e em sua orla \\ os pássaros de sempre cantam \\ nos hospícios. \\ (...) \\ (não se fala. não é permitido: \\ mudar de ideia. É proibido. \\ não se permite nunca mais olhares \\ tensões de cismas crises e outros tempos. \\ está vetado qualquer movimento (NETO, 2004, p.168)
}


Por conta mesmo destas "ciladas das palavras" e da proximidade das relações (Pelbart afirma mesmo uma forma de relação de vizinhança entre as duas) é que uma distinção entre loucura e desrazão se faz problemática, o que incide por vezes no erro de dizermos loucura ao queremos dizer desrazão, e desrazão ao queremos dizer loucura. Nestes casos, damos uma certa dose de desconto para o teórico/escritor, pois cremos também caber mais uma necessidade de perspicácia e atenção do leitor para poder discernir o que está em questão - o que evita também más intenções em leituras e interpretações. Uma das dificuldades em se pensar a desrazão está contida na própria formação da palavra, já que em sua grafia ela "desfaz a razão" (o uso do prefixo des), ou está ausente dela, sem a contradizer, já que ela escapa ao sujeito, ao Humano.

A proeza principal da aparição da ideia de desrazão se localiza no fato de ter, ou pelo menos de surgir como opção para tal, operado uma dissolução de um racionalismo bastante nocivo. Este diz respeito a oposição existente entre a refutação e o menosprezo completo das criações provenientes de delírios ou estados de loucura, e a sua idealização e excessivo vangloriar. Não se trata nem de diminuir ou ignorar a importância destas invenções, nem tampouco de elevar elas a tal grau de elogio que passe a ser objeto de veneração e busca de alcance do estado; ou seja, nem entregar o louco aos leões (como Foucault evidenciou em parte de sua História da Loucura), nem colocá-lo em um pedestal (querer se transformar em louco ou forjar ser um é evidentemente uma grande tolice). A desrazão define condições passageiras e escapes. Vendo a dificuldade e o perigo de por vezes misturar as duas coisas, e para evitar este transtorno nocional, Peter Pál Pelbart preferiu ao se indagar sobre produções artísticas fruto do desatino (notadamente no caso da linguagem e da literatura) -, pensar a partir do conceito de fora concebido por Blanchot, e noção presente em L'Écriture du Désastre.

Esta aproximação do conceito do pensador francês faz com que as criações desarrazoadas se avizinhem bastante das órbitas do desastre, ao ponto de Pelbart nos deixar com a impressão de, ao falar de uma, estar na verdade falando da outra, ou das duas - e é justamente assim em uma rede, rizoma ou comunidade de pensamento. Quando ainda dizendo da distância entre loucura e desrazão, afirma o filósofo $(2009$, p.57):

(...) enquanto a desrazão é a experiência percebida como inumana, atemporal, imaginária e onipresente, que enuncia, no silêncio ou na desforra, uma verdade $d o$ mundo, a loucura remete à experiência temporal, de um tipo social excluído, e que exprime, no excesso de suas paixões, a verdade do homem.

Aí se encontra, na esteira da desrazão, mais um motivo da dificuldade em aprisionarmos o desastre em qualquer forma mais racional de expressão: ele diz de uma verdade que não se encontra necessariamente no homem, que apesar de poder participar de suas experiências, não diz 
diretamente dele, e somente a ele. As experiências da desrazão podem operar como expoentes do desastre, pois ela é "afetiva, imaginária e atemporal" (PELBART, 2009, p.55), ao contrário da loucura que se limita ao "temporal, histórico e social" (ibid., p.55). A confusão entre tempos, a impossibilidade em se situar se faz marca. Dois trechos retirados do diário escrito por Maura Lopes Cançado em um de seus períodos de internação, traçam relações com esta ideia do tempo diferenciado, próximo ao esquecimento próprio ao desastre blanchotiano:

(...) Ainda que só diante do louco tenha experimentado a sensação de eternidade. Nele não encontramos a falta. Nos parece excessivo, movendo-se noutra espécie de vibração. Junto dele estamos sós. Não sabendo situá-lo fica-se em dúvida: onde se acha a solidão? O louco é divino na minha tentativa fraca e angustiante de compreensão. É eterno.

(...)

Visitei-me no futuro: a memória não tem culpa. Sou a desocupada no tempo, a não fixada. (CANÇADO, 1988, p.26/131)

Nestes trechos, a eternidade e a confusão entre divisões temporais (passado, presente, futuro) nos faz recair em mais um dos enigmas próprios ao desastre, e que são próximos à loucura. A escrita proveniente do disparate se aproxima vertiginosamente do desastre, colocando em jogo e nos fazendo deparar com outros de seus elementos. Novamente uma citação de Pelbart, ao mencionar o trajeto que percorreria em seu livro, pode nos auxiliar a compreender essa afirmação:

Veremos, por exemplo, como a arte, quando se expõe ao Acaso e à Força, gera o Caos-germe; ou como a linguagem ao entrar em contato com a Ruína, implode num Desobramento; ou ainda, de que modo o Desconhecido, quando irrompe na experiência cotidiana, o faz sob o signo do Neutro. Nomes distintos (e insólitos) para se falar, afinal, de um mesmo feixe de "experiências" e "modalidades de funcionamento". Ocorre que em cada campo essa turbulência "funciona" de um modo específico e cada autor a "experimenta" e designa a seu modo. (PELBART, 2009, p.67)

Somados a estes elementos mencionados, e remontando ao início desta pesquisa, identificamos como o fragmento e a força fragmentária estão mais do que vivos nos escritos da desrazão, inclusive em suas reuniões, já que os livros dos autores brasileiros aqui lidos quando não são inteiramente compostos por uma obra póstuma fruto da reunião de escritos os mais variados, de uma miscelânea de gêneros e anotações dispersas (como com a Torquatália de Torquato Neto), conferem em sua estrutura aparentemente romanesca um claro inacabamento (como no $O$ Cemitério dos Vivos de Lima Barreto), em cortes cronológicos desiguais (o livro-diário Hospício é Deus de Maura Lopes Cançado), ou ainda em intensas rupturas, digressões e fragmentações capitulares (como em A Saída do Primeiro Tempo e Quatro Olhos de Renato Pompeu ou Todos os Cachorros são Azuis e O Esquizoide - Coração na Boca de Rodrigo de Souza Leão). Vale lembrar que não se 
trata apenas do caráter híbrido que este conjunto de textos suscita, mas como no próprio desbravamento de cada um destes textos vemos a constante visitação de elementos do desastre. A característica do inclassificável passa a fazer parte destes autores, que dificultam ao máximo a categorização e a plena compreensão, dadas à análise cientificista e racional.

O louco se vê exposto a questões com as quais não pode criar grande resistência, e quando estes são ou se tornam escritores, a literatura passa a ser mais uma dessas questões. Impulsos nos quais acabam se entregando inteiramente, embutindo em cada um deles energias bastante peculiares, insensatas e obstinadas. O escritor e jornalista campineiro Renato Pompeu relata momentos em que percebia em si fortes indícios de delírio que se tornavam cada vez mais perniciosos a ele (em termos sociais, de convívio) na medida em que embaralhavam as fronteiras entre realidade e ilusão. Foi a partir daí que diz ter buscado tratamento mais intensivo, sendo uma de suas estratégias para controlar seus desatinos transportar para, e como que isolar estas ocasiões, a criação literária e teórica. Somente assim, através da linguagem, é que o escritor pôde como que “... descolar-se de si ...” (PELBART, 2009, p.49). Ciente da condição de conviver até o final de sua vida com a simultaneidade entre consciência e inconsciência, sobriedade e delírio, sono e vigília, a literatura se torna válvula de escape (um fora?) que não o livra do perigo da loucura (pode até muitas vezes aproximá-lo e levá-lo a um ponto sem volta, como foi talvez o caso de Nietzsche), mas o direciona para uma forma de produção (o próprio Pompeu afirma ser extremamente necessário para o controle da loucura que o louco esteja sempre ocupado, se mantendo em movimento de alguma maneira).

Com Rodrigo de Souza Leão, particularmente em Todos os Cachorros são Azuis, este “descolar-se de si” é incessante. O autor descreve instantes nos quais há um movimento intenso de vai e vem, como se entrasse e saísse de si em ações fugazes, como em rajadas desarrazoadas. Sua projeção em outros animais e objetos, espécies de devires que o invadem, é uma constante em seu texto. Crer ser um golfinho deitado ao divã, virar uma planta durante uma sessão com sua psicóloga, fumar um cigarro de maconha dentro de um elefante e soltar a fumaça por sua tromba, quebrar e desordenar tudo por ser feito de cacos, se transformar em uma máquina que só escreve o que ele quer, e procurar no mundo de fora todo dia o seu nome no obituário, são alguns dos exemplos destes movimentos ${ }^{22}$.

Os acessos de loucura, assim como aqueles da literatura e da escrita, são forças com as quais muitas vezes não se pode lutar, mesmo se debatendo, e é provavelmente também por isto que a obstinação dos loucos componha tantas invenções admiradas (os exemplos na literatura são variados, assim como na arte pictórica com Van Gogh e a experiência brasileira do Museu do

\footnotetext{
${ }^{22}$ Todos eles retirados de diferentes momentos de Todos os Cachorros são Azuis.
} 
Inconsciente, ou no teatro com Qorpo Santo e Artaud). É como diz Pelbart (2009, p.133) ao lidar com a literatura: "Com efeito, os escritos loucos comprovam que a escritura se presta a ser um jogo intensivo de formas e gestos, impulsos, violências e graças". A necessidade pura de uma escrita da desrazão é permeada por uma força incontrolável, inapelável e inadiável, em plena sintonia com a escrita do desastre.

Gostaríamos, por um breve instante, de ressaltar alguns pontos de encontro entre os autores brasileiros aqui reunidos, não para forjar biografismos, mas com o mero intuito de poder reuni-los de forma mais consistente em torno da ideia de comunidade aqui proposta, na identificação de movimentos similares em seus escritos, que possibilitam diálogos, ou mesmo alguma fala em comum - no caso, a da desrazão.

Existem evidentemente inúmeros motivos e enfermidades pelos quais as pessoas passam para enfim decidirem se internar em hospitais psiquiátricos (ou em casos mais drásticos quando outras pessoas necessitam decidir por elas). Além do fato comum de perpetuarem a paixão e o afeto pela literatura, e de identificarem a aparição de delírios em seu cotidiano, estes autores se cruzaram [há inclusive uma breve menção no diário de Torquato Neto ao livro de Maura Lopes Cançado: "tem um livro chamado: o hospício é deus. eu queria ler esse livro. foi escrito, penso, neste mesmo sanatório. vou pedir a alguém para me conseguir esse livro.” (NETO, 2004, p.324)] na própria razão de suas internações. Lima Barreto e Torquato Neto, por exemplo, sofreram ambos com as tentações do alcoolismo, Barreto por profetizar um porvir, um futuro de desgraça social e econômica para si, e Torquato por sentir cada vez mais presentes vontades suicidas, desestímulos para seguir com a vida. O partilhar de fármacoexperiências ocorre no caso de Renato Pompeu e Rodrigo de Souza Leão, que mencionam uma mesma medicação, o Haldol, pílula utilizada com o intuito de controlar e desaparecer com as alucinações. As reações quanto ao uso deste remédio, no entanto, são divergentes entre os dois: enquanto Pompeu credita ao uso desta medicação a atenuação e o controle dos delírios, Souza Leão culpa o uso da mesma como catalisadora de um de seus surtos - no qual entrou em colapso paranoico, invadido pela vontade de quebrar tudo o que via pela frente, causando grande estrago na casa de seus pais e o levando à internação que parece ser a mais relatada em Todos os Cachorros são Azuis. Há ainda uma analogia encontrada tanto em Lima Barreto quanto em Rodrigo de Souza Leão: a relação de semelhança entre os hospitais psiquiátricos e os cemitérios. Em Barreto isto está presente tanto no próprio título de seu romance O Cemitério dos Vivos, quanto na impressão de que esse era um local em que as pessoas apenas vagavam, quase como mortosvivos; já em Souza Leão temos um trecho que diz dessa ligação, da similaridade inclusive das paisagens: "Havia muitas flores em toda clínica. Era um lugar bonito. Por isso digo que hospícios são lugares bonitos que lembram os cemitérios. Aqueles cemitérios onde há enormes jardins" 
(SOUZA LEÃO, 2010, p.53).

Estas identificações em comum, que admitimos serem de ordem mais de diagnóstico médico, psicológico e social do que literário ou filosófico, nos interessam ainda, pois nos possibilitam a construção de uma ponte direta com algo que Foucault afirmou e que Pelbart coloca em evidência: a de que os sintomas da loucura em uma sociedade são o espelho de sua própria condição (ao ponto das medicações ou métodos de tratamento serem parecidos ou iguais). As formas de loucura advindas refletem a sociedade vigente, e vice-versa. Esta afirmação incide em uma relação entre doença e cultura. Sabemos que este não é necessariamente o caso da literatura, onde um autor pode forjar uma dada época em seu tema ou estilo de escrita, sem necessariamente viver nela, no entanto nos interessa este espelhamento criador e sem um contato de domínio ou mera denúncia realista.

Falando do século XX, e provavelmente possamos estender para pelo menos o início do século XXI, Pelbart se apoia na tese de Foucault e de Georges Devereux para dizer que "a sociedade contemporânea é esquizoide e a esquizofrenia é sua caricatura" (PELBART, 2009, p.181). Sendo o esquizofrênico o ser que mergulha na profundidade do delírio, ao ponto de chegar à indiscernibilidade, para o escritor, a literatura proveniente deste estado deve retornar a qualquer custo - da imersão no desvario - com espécies de infrassentidos possíveis: “A esquizofrenia seria o colapso da superfície e a queda na profundidade, segundo um modo específico" (ibid., p.130). É importante ressaltar que esta noção de superfície está ligada à sobriedade - o que seria a possibilidade de conseguir carregar da imersão a uma profundidade, através de zonas de turbulência sem dúvida, estes infrassentidos. Neste caso não há como não lembrar principalmente de Rodrigo de Souza Leão.

O escritor carioca foi diagnosticado com esquizofrenia, e este seu estado claramente se transporta para sua escrita. O detalhamento de acontecimentos pelos quais passou, assim como a leitura que realiza do ambiente que o cerca - com especial ênfase no cotidiano de confinamento estão atados a sua enfermidade. Pelbart, na esteira de Devereux, indica a semelhança que pode haver entre a estrutura da psicose e o da sociedade contemporânea, e no caso do esquizofrênico isto se torna ainda mais evidente, pois ele "concentra traços de comportamento típicos da civilização que o rodeia" (PELBART, 2009, p.176). O filósofo lista ainda cinco desses traços sendo o primeiro o que mais nos chama atenção, notadamente a partir da leitura de Todos os Cachorros são Azuis e $O$ esquizoide: "sexualidade restrita à fornicação, sem conteúdo afetivo, ou, mais prosaicamente, incapacidade de amar” (ibid., p.176). São inúmeras as aparições de exemplos deste traço no livro do escritor carioca, no que diz respeito à masturbação e ao infortúnio no amor, nas paixões por figuras femininas com as quais convive quando da clausura. 
Além desta constatação, outro aspecto que parece espelhar a escrita de Souza Leão com o contemporâneo é a maneira visceral com que despeja as frases. Em um paralelo com a edição imagética ou ainda audiovisual, diríamos que a velocidade alucinada com que se dá seu texto se aproximaria bastante de uma linguagem videoclípica. Os cortes que imprimi se aproximam de faux raccords ou jump cuts cinematográficos. É sabida também a influência direta da tecnologia e da informática no século XXI, componentes já da experiência e do próprio corpo do ser, o persistente leitmotif catalisador do delírio: "engoli um chip quando tinha 15 anos" em Todos os Cachorros são Azuis ou a bomba que diz ter alojada dentro de si em $O$ esquizoide. Curioso é notar como apesar de se transportar desregradamente no texto para os mais diversos tempos e espaços, o autor continua de alguma maneira a estar situado, ou ao menos em relação direta com a época em que viveu. As interações entre o dia a dia do hospício com os amigos literário-imaginários do escritor, Rimbaud e Baudelaire, é muito interessante, pois carregam marcas biográficas dos próprios poetas franceses que viveram no século XIX. Nesta forma de escrita - descontínua, incessante e fragmentária Souza Leão escreve de tal maneira que "o efeito de linguagem torna-se para o esquizofrênico, linguagem-afeto" (PELBART, 2009, p.128).

É importante finalmente frisar que nossa intenção não é a construir um gênero, ou o de enquadrar estes autores em uma categoria, o que nos parece fator de enfraquecimento de diversas ordens durante as possibilidades de interpretação e produção a partir destes escritos. Seria, em nossa visão, altamente empobrecedor reunir estes autores apenas por supostas similitudes, renegando assim um caráter singular a cada um deles e que pode ainda sempre estar em processo por pensar. Assim, mantivemos em vista uma frase do próprio Rodrigo de Souza Leão (2010, p.51): "Há um enigma por detrás de cada louco". Não nos interessa a plena definição, preferimos optar e desbravar trilhas em direção ao que afirma Peter Pál Pelbart (2009,p.156): “Os poetas loucos não realizam a síntese entre um gênero literário e outro psiquiátrico, mas expressam a desrazão com as máscaras que esse século e outros talvez lhe reservaram: a arte e a loucura".

Para tanto observamos a possibilidade de trabalharmos com um aspecto específico e bastante rico nos livros dos escritores brasileiros aqui reunidos, o dado do testemunho, e como ele opera em cada um dos autores.

\section{$\underline{3.3}$ O Testemunho-Ficção}

Em 1998 o filósofo Jacques Derrida escreveu um livro intitulado Morada - Maurice Blanchot, a partir de um dos últimos textos publicados em vida por Blanchot: O Instante da minha 
morte. Este texto consta do testemunho de um acontecimento passado no crepúsculo da segunda guerra mundial, quando a França já estava sendo retomada pelos aliados, mais precisamente no dia 20 de julho de 1944, quando, por muito pouco, Blanchot não fora fuzilado por soldados russos (que pensava até quando próximo da morte serem alemães). Em seu livro, Derrida se debruça sobre este intrigante ato que dispara relações entre a ficção e a verdade autobiográfica, portanto, entre a própria literatura e o testemunho. É em meio a dúvida e a especulação que o filósofo francoargelino vai desenvolver seu pensamento, afirmando logo no início do livro: “... não sei se [o texto de blanchot] pertence ou não, de modo puro e próprio e estrito e rigoroso, ao espaço da literatura, se é uma ficção ou um testemunho, e sobretudo até que ponto põe em causa ou faz tremer todas estas partilhas" (DERRIDA, 2004, p.20).

O ponto de partida para Derrida é a compreensão de como é tomada a ideia de testemunho dentro do senso comum. De pronto, sua definição está ligada a questões referentes ao campo jurídico, a um pronunciamento oral que se dá em frente a um tribunal, e que diz respeito a um contrato e uma atestação da garantia de verdade e boa fé na transmissão de informações que se tornam públicas na medida em que estão sendo proferidas. Durante um julgamento, a mentira é tida como altamente perniciosa, é necessário que ela se torne temida como nenhum outro fator (quem mente está apto a sofrer severas punições) para que advenha a verdade, e somente ela. Neste caso, a obra de arte não poderia aparecer de forma alguma, já que nela não há garantia de veracidade, assim, apenas a realidade pode estar presente, ao custo da ilegitimação. A lei teme então a mínima probabilidade de ficção, pois é ela quem "assombra, como sua própria possibilidade, o testemunho dito verídico, responsável, sério, real. Essa assombração é talvez a própria paixão, o lugar passional da escrita literária, como projecto de dizer tudo (...)" (ibid., p.76).

Blanchot opera um desvio desta faculdade jurídica, colocando mais uma vez a literatura em risco, na esperança de habitar, permanecer mesmo que provisoriamente (há aqui o jogo com a palavra demeure no francês que se perde ao utilizarmos a língua portuguesa) entre a pequena fissura que pode existir entre a verdade e a mentira, o verdadeiro e o falso. Diz Derrida (ibid., p.32):

É desta possibilidade sempre em aberto - e que deve continuar a sê-lo, para melhor e para pior - é que vamos ocupar-nos. É aí que uma paixão da literatura teria lugar, é aí que ela teria um dos seus lugares senão o seu próprio lugar.

Localizando-se nesta tensão entre a realidade e a ilusão, a invenção, é que o relato transformado em texto vai ganhar espaço. É talvez principalmente por seu caráter passional (dizemos comumente quando alguém age impensadamente, de maneira como que irracional, que este indivíduo está agindo de forma "passional") que a literatura invade um escrito, e no caso do 
testemunho ela sempre estará passível de sofrer acusações difamatórias, por não estar interessada pura e simplesmente em atestar, em dar prova de algo sob contrato firmado com a verdade. Trata-se então de deixar recair sobre o testemunho a possibilidade da literatura, que ela possa se infiltrar e injetar suas substâncias, fazendo com que ele passe a operar em uma nova lógica.

Mas não é apenas da dissonância entre o relato e a ficção que sobrevive a relação entre testemunho e literatura. Existem certamente características em ambas que acabam alimentando e potencializando esta mistura. Aqui, a ideia de experiência é bastante valiosa, pois como escreve Derrida (2004, p.29): “Ocular, auditiva, táctil, a percepção sensível da testemunha deve ser uma experiência". Quando transmitida para a escrita, livre do fardo do pronunciamento presente e público, o testemunho pode enfim especular outras formas de efetuação, sem necessariamente perder este caráter da transmissão do acontecimento de uma experiência. Derrida convoca também neste sentido do testemunho, de uma completa entrega pessoal que pode haver no relato, a figura do mártir, aquele que "quando testemunha, não conta uma história, oferece-se" (ibid., p.35). É nessa força que os escritores brasileiros trabalhados neste capítulo parecem habitar, principalmente Rodrigo de Souza Leão e Maura Lopes Cançado, pela intensa exposição de si com que relatam, ou melhor, se oferecem.

No caso de Blanchot, o grande fantasma ou a grande presença que assombra suas palavras está contida na possibilidade da morte, no ultrapassar do que nomeou como uma "experiência inexperimentada". Como observado por Derrida (ibid, p.45), apesar de estar mais claramente perceptível em $O$ Instante da minha morte, esta ideia já está presente em L'Écriture du Désastre, e o testemunho de Blanchot talvez seja mesmo fruto desta escrita (parece até que o pensador francês só se sentiu pronto a relatar este acontecimento depois de ter realizado todo um trajeto de pensamento, pois se não foi esse o caso, por que esperar tanto - 50 anos separaram o evento do texto - para escrevê-lo?). Por meio de mais uma de suas expressões que levam a nós aparentemente impossíveis de serem desatados, o pensador francês transmitiu a sensação, a presunção, a impressão de ter se sentido levado pela e para a morte, entregue a seus enigmas, e a um estado no qual o ser vivente não teria como testemunhar. Este estado se assemelha bastante da condição da loucura (talvez ao ponto de podermos usar as mesmas palavras para também dizer dela). $\mathrm{O}$ pensador francês confessou o inconfessável por meio de sua quase-morte, enquanto os autores brasileiros aqui mencionados o fizeram através da quase-loucura. O desarrazoado fala da loucura a partir do mesmo sentimento de ter vivido uma "experiência inexperimentada", já que é sem retorno também o mergulho total e irreversível que pode haver neste movimento. É provavelmente neste estado sempre provisório, que ainda se pode trazer algo para a vida ou para a produção. Neste suposto retorno sem chegada é a literatura que faz com que a autor-narrador-personagem - veremos adiante como opera esta tríade - 
possa se aproximar do estado pressentido.

Nesta pesquisa em curso, nos autores brasileiros que aqui destacamos, o mediador entre testemunho e ficção é o delírio. Pela aproximação que observamos entre morte e loucura, torna-se facilitado o diálogo com as perspectivas de Blanchot e Derrida. Cabe salientar que não pretendemos de forma alguma descobrir o que é verdadeiro e o que é falso em cada fala, pois não se trata de levantar véus ou descortinar partes do texto no intuito de revelar uma distinção entre mentira a verdade (isto evidentemente é a tarefa jurídica, investigativa, da lei). Trata-se então de pensar como as definições de fatos verdadeiros ou falsos passam a uma condição de desimportância, pois são eclipsadas por outros parâmetros, como é notadamente o caso da experiência na audição destas vozes exiladas. Talvez seja o momento de falarmos não em desimportâncias, mas em inverdades. Esta palavra - retirada do título de um dos livros do escritor brasileiro André Sant'Anna - faz referência à fuga de uma ideia factual: das inverdades nada se pode confirmar, ao contrário do que ocorre com os fatos, que só podem ser verídicos ou falsos. Esta característica se assemelha bastante com a força de um testemunho transportado à ficção. Em um trecho de $O$ Esquizoide, de Rodrigo de Souza Leão, vemos a exposição desta queda da condição factual: “- Tenho uma bomba na cabeça. É uma bomba imaginária? - Imaginária no sentido de que é uma coisa que modificou a minha estrutura celular. Meu corpo não responde aos mesmos chamados do mesmo jeito" (SOUZA LEÃO, 2011, p.73). Neste caso, a acepção da palavra "imaginária” sofre uma turbulência, é transtornada na medida em que é indicada como força desestruturadora da lógica interna do organismo; para o narrador, esta bomba que ele possui alojada em sua cabeça não é mera ilusão ou metáfora para outras significações, mas passa a fazer parte de sua anatomia, mesmo que inexistindo materialmente, de forma palpável.

Interessa-nos a rachadura que pode ser produzida no transporte do testemunho para a literatura, nesta possibilidade de "falar verdade aqui e mentir além, entretecer uma série de interpretações, conotações, de reflexões, de incidências inverificáveis em torno de uma trama ou de uma cadeia objectivamente provada e insuspeita" (DERRIDA, 2004, p.56). O testemunho transformado em literatura segue o movimento próximo ao de uma "ficção teórica" (ou "teoria fictícia" como preferiu Blanchot em L'Écriture du Désastre), aquela que ao despejar todo um arsenal conceitual, o faz por meio de invenções, de certos meios e feições literárias (introdução de cenários e personagens, uso de metáforas, desmantelar do discurso etc.), por exemplo. Afirma Peter Pál Pelbart (2009, p.140):

Contra o platonismo científico dominante, a questão não é mais a de saber se aquilo que aqui leva o nome de ficção teórica corresponde ou não à realidade, mas em que sentido ela funciona, que efeitos gera e que desdobramentos ela trava. É o que se 
deveria entender quando Foucault diz que em toda sua vida só escreveu ficções (e que escrever, como o disse Deleuze sobre ele, é lutar, devir, cartografar).

Gostaríamos de analisar, neste momento, de que modo se dá a mistura entre testemunho e ficção nos autores brasileiros referidos por nós como registradores de dados testemunhos da desrazão. Todos estes escritores registraram suas experiências de internação em hospitais psiquiátricos, e sobre (ou ainda sob) estados de delírio, e acreditamos ser bastante pertinente a maneira como cada um deles o fez, e em qual grau de relação com a fíção e a literatura.

Lima Barreto esteve internado em um hospital alienista do Rio de Janeiro e registrou em um diário vivências e conhecimentos da rotina neste espaço, durante o início da década de 20 . Nota-se em seu Diário do Hospício uma curiosidade atenta quanto aos personagens que o circundavam, deixando o leitor como que avisado de que daquele ambiente certamente poderia advir um romance, um conto ou etc. Interessante também é a lucidez do autor nas recorrentes análises que faz do ofício dos alienistas no Brasil (realiza inclusive breves comentários sobre figuras importantes na história da psiquiatria brasileira com quem teve contato pessoal) e de que maneira cada um deles absorvia e praticava os novos métodos de tratamento que surgiam com o passar dos anos. Este material configura certamente valiosa fonte para estudiosos da área, pois traça o cenário de um período histórico da psiquiatria e de novos tratamentos com loucos que brotavam aos montes - desde sua recepção, provenientes que eram de teóricos europeus, quanto de sua adaptação ou não-adaptação ao contexto brasileiro.

Em uma breve visita de um jornalista que fora ao local para entrevistá-lo, Barreto já dava algumas pistas e adiantava uma ficção por vir a partir de sua internação, o que ocorrera parcialmente (pois este texto ficou, e acabou sendo mesmo publicado, de forma inacabada) na obra batizada de $O$ Cemitério dos Vivos. Percebe-se como salta aos olhos do autor as mazelas do homem que se situa à margem de uma sociedade, e a particularidade das histórias e dos atos de cada um deles. Quase como em um estudo, Barreto (2010, p.210) anota: "(...) o horror misterioso da loucura é o silêncio, são as atitudes, as manias mudas dos doidos". Neste ponto identificamos nele uma espécie sempre atenta de desrazão sociológica, onde o meio que o circunda, o momento histórico pelo qual atravessa a sociedade, influencia bastante o olhar e consequentemente a escrita do autor. Como já dito, Barreto se entrega ao alcoolismo - e acaba encontrando os delírios, a ausência de separação entre realidade e ilusão - por se ver próximo de uma situação de marginalidade e malogro social. Mesmo ainda contendo um estágio de alta separação entre diário e romance, testemunho e 
ficção - para Barreto o diário acaba funcionando como um livro de consulta e referência para a construção de um romance - vemos como o autor deixa escapar indícios de sua ficção no próprio diário (não podemos precisar exatamente se isto se passa dentro do equívoco, da indefinição do inacabado, da dúvida, ou até de um delírio, no borrar das distinções). Menciona por vezes uma esposa e uma mãe que não existiram em sua biografia (o autor nunca se casou e perdeu a mãe ainda menino), mas que passam a existir em $O$ Cemitério dos Vivos (título bastante sugestivo quanto a visão construída pelo escritor no período de sua internação). Além destas aparições fíccionais em seu diário temos ainda rasuras em algumas palavras, como no caso de nomes que eram reais, mas que o autor optou por ocultar. É como se o testemunho servisse de base para estruturar a ficção, e a ficção para desestruturar o testemunho, através de um diálogo ativo. Em Lima Barreto temos um testemunho ainda sob contrato firme com a realidade, nele, as forças que o delírio pode alcançar na literatura ainda estão atenuadas, mantidas em quietude, apenas pressentidas por leves espasmos. Seu texto testemunhal serve, portanto, como objeto de estudo laboratorial para a ficção, em forma quase total de espelhamento, sem grande fusão criadora.

Um trecho do prefácio de Hospício é Deus escrito pelo jornalista e colega de Maura Lopes Cançado, Reynaldo Jardim, expõe de forma bastante sagaz o modo pelo qual a experiência da desrazão ocupou o livro da autora, atravessando de forma cabal a relação aqui em evidência entre testemunho e ficção:

O desvario é farsa? Mas a que ponto atinge a farsa? A farsa despedaça o próprio corpo no fio da gilete e tranca, entre grades, a alma em sangue? Como a própria língua? Acende em holofotes os próprios olhos e os torra no espelho da memória? Então é desvario. Mas o desvario esquadrinha os meandros da linguagem e expõe o verbo sofrer em forma substantiva? Explica o sentido de gesto não concluído, deduz a equação mal esboçada, dá sentido ao Céu e, deliberadamente, provoca pânico entre os anjos?

Existe a fronteira. Existe? A mentira é tão verdadeira quanto a verdade, pois a verdade é uma convenção de mentirosos. (CANÇADO, 1988, p.9)

Neste trecho, a primeira porção de frases interrogativas nos abre para a dúvida, em uma especulação que desemboca em uma primeira afirmação: a de que há o desvario. Novas interrogações então se sucedem, chegando a uma segunda afirmação: a de que há sim uma fronteira (entre mentira e verdade, sanidade e insanidade), mas que logo depois, no segundo parágrafo citado, desconfia de si, se trai, retornando e devolvendo a pergunta, ao limiar onde ao mesmo tempo em que se afirma, se duvida, em um lugar onde é possível afirmar a dúvida, ou melhor, local onde a dúvida se afirma. Nos escritos de Maura - e podemos estender a dos outros autores que estudamos mentiras e verdades se equivalem, importando mais a força sensível e a carga de poeticidade que 
podem exprimir nelas e entre elas.

A escritora mineira manteve - por sugestão de seu psiquiatra, pelo qual nutria uma projeção romântica - durante o final da década de 50 e o início da década de 60 um diário no qual registrava a experiência de uma de suas passagens pelo Centro Psiquiátrico Nacional, no bairro do Engenho de Dentro localizado no Rio de Janeiro. Chama a atenção a lucidez com que relata seus próprios acessos de loucura e violência. Seu texto se aproxima, principalmente no início, de uma autobiografia, já que remonta a sua infância, sem a marcação de datas, até chegar ao presente instante de internação e registro do diário, no dia 25-10-1959. Talvez por este caráter de inventário, de rememoração, este relato serviu bastante para que os profissionais de psiquiatria que cuidavam de Maura pudessem de alguma maneira definir uma enfermidade e cravar um diagnóstico a respeito de sua condição - ou seja, se tornou provavelmente objeto de estudo científico.

Percebe-se claramente em Cançado como a memória é uma forma de ficção, um olhar sobre uma situação, uma perspectiva, uma farsa altamente legítima. Apesar de ser bastante pessoal, seu testemunho já ganha leves contornos de uma mistura de gêneros, pois a autora insere partes de contos seus, assim como de poemas, se aproximando assim de uma colagem textual. A essência autobiográfica do testemunho da qual fala Jacques Derrida está muito presente em Hospício é Deus. Assim como em Lima Barreto, as personagens com as quais conviveu Maura em sua internação se tornam matéria literária para sua ficção, como no livro (junto com este livro-diário os únicos publicados da autora até hoje) $O$ Sofredor do $\mathrm{Ver}^{23}$ - bastante aclamado na época de lançamento, suscitando a atenção de escritores já ativos e hoje bastante reconhecidos como Carlos Heitor Cony e Ferreira Gullar, sendo Maura tida como uma escritora de grande talento e futuro promissor.

Iniciando uma questão que se repetirá em Renato Pompeu e Rodrigo de Souza Leão, Maura Lopes Cançado põe em xeque a forma com que nossa sociedade define e lida com seus ditos "loucos", sendo esta maneira bastante oportuna e hipócrita. $\mathrm{Na}$ incorporação de personagens sociais, o louco passa a ser um indivíduo marginalizado já que não se enquadra em padrões objetivos e dados à utilidade, na produção de alguma coisa na qual a sociedade considera "útil” para seu pretenso desenvolvimento. Diz Cançado (1988, p.87): "Que se deve fazer destas pessoas para as quais não existe nenhum cargo funcional? Eu me visto de doida, desempenho meu papel com certa elegância, sobretudo muita graça. Seria mais fácil fantasiar-me de funcionária pública, trabalhando em hospício". Neste exemplo, como em outros trechos de seu texto nos perguntamos: como uma louca pode ser dona de e portar tanta lucidez? Não estaria a própria definição de loucura distorcida em nossos saberes? Foucault nos mostrou que sim em seu História da Loucura apontando, na esteira de uma genealogia/arqueologia a partir do fim da idade média, as formações/construções e

\footnotetext{
${ }^{23}$ CANÇADO, Maura Lopes. O Sofredor do Ver. Rio de Janeiro: José Álvaro Editor, 1968.
} 
os desenvolvimentos das maneiras como se lidou com os loucos na sociedade ocidental, chegando enfim a uma melhor compreensão do porquê os tratamos do jeito que os tratamos - neste pensamento de uma mera "inutilidade" supostamente inerente.

A sensibilidade e a escrita de Cançado caminham por uma direção portadora da pulsão e do peso do desabafo, da confissão, por se tratar de um olhar tão subjetivo e peculiar. Tanto as personagens companheiras internas da escritora mineira, quanto as funcionárias que as vigiavam, são referidas diretamente, sem qualquer omissão identitária, o que não ocorre com os médicos que são denominados apenas por letras, ou provavelmente iniciais, como é o caso do Doutor A - o que demonstra uma certa hierarquia considerada talvez pela própria autora, na garantia deste anonimato. A descrição realizada por Maura das personagens que a circundam nos remetem a uma cena clássica do cinema: a chegada de Irene, interpretada por Ingrid Bergman, ao hospital psiquiátrico em Europa 51 de Roberto Rosselini, onde a câmera passeia pelos rostos das internas, capturando a intensidade e o estranho fascínio de seus olhares e gestos.

A vigília do desastre parece ser elemento bastante vivaz na escrita e na própria relação que Maura tem com a produção de seu testemunho. Não é raro encontrar em seu livro/diário menções a estados próximos à imagem de uma insone do dia como colocada por Blanchot, que vê em tudo o que olha, e no que pensa olhar, intensidades que podem levar a captações literárias, condição onde não há descanso, em uma motricidade incessante que inquieta aquele que é afetado. Quando a escritora se vê inapta a colocar estas sensibilidades no papel, se sente esgotada, impotente, infeliz: suas forças se encontram completamente acossadas.

Os escritores Torquato Neto e Renato Pompeu viveram períodos de internação durante a década de 70. O poeta piauiense e o jornalista e romancista campineiro não chegaram a incluir mais diretamente em seus trabalhos considerados ficcionais experiências de confinamento, mas escreveram relatos acerca destes períodos - Torquato em um breve diário que manteve quando da internação no Centro Psiquiátrico Nacional no Rio de Janeiro e Pompeu com um pequeno livro chamado Memórias da Loucura.

Por meio dos escritos do poeta vemos como sua internação era realmente uma tentativa desesperada - nas palavras do organizador de sua obra Paulo Roberto Pires - de "cimentar uma experiência que apontasse alguma saída existencial ou estética” (NETO, 2004, p.319). Talvez esta busca fosse mesmo a procura por algum norte, já que tanto na vida quanto na arte se sentia deslocado - e não haveria também aí para ele uma ausência de separação (o famoso verso de “desafinar o canto dos contentes")? Isto se reflete na diversidade de escritos que constam na espécie de antologia de sua produção, a Torquatália, dividida em dois volumes, que concentra escritos da 
época em que estava envolvido com o movimento tropicalista (sobretudo em textos para televisão, teatro e cinema), de sua poesia (a ativa participação em revistas literárias como a Navilouca, ao lado de seu amigo Waly Salomão), de seu cancioneiro, de sua correspondência (as cartas trocadas com Hélio Oiticica são bastante sintomáticas dos anos de Tropicália) e de anotações soltas e esparsas (como é o caso de seu breve diário do engenho de dentro).

Este caráter híbrido, de múltipla colagem, reunião de escritos esparsos anotados em cantos e nesgas de papel as mais diversas (um maço de cigarros, um guardanapo, um caderno ou uma agenda, não importava) apontam para uma pluralidade com a qual se debateu incansavelmente, na busca talvez por aquela saída estética, que acaba encontrando neste movimento de perseguição a sua própria efetuação. Torquato nos deixa o legado deste múltiplo que, mesmo disperso, pode produzir, deixando a impressão de que os processos são sempre mais relevantes do que supostos inícios ou fins (predisposições e objetivos). Valoriza, assim, a exposição de uma potência do fragmentário.

Em Memórias da Loucura, Renato Pompeu descreve o que para ele seriam métodos eficazes de controle dos delírios, expondo suas experiências em internações, e o que considera ter funcionado em seu caso para conter o desatino. Ele foi o único destes autores a ter passado - ou ao menos relatado - pelas chamadas comunidades terapêuticas, ambientes onde os loucos convivem com liberdade, se reunindo em um grupo de ajuda mútua, que recebe a visita de profissionais da área de psicologia e médica. Não há neste caso a situação de uma clausura - a opção por esta vivência parece ser bastante voluntária. Afirma que este tipo de comunidade tem papel fundamental para o louco, pois atua onde ele mais necessita: "Para evitar a loucura, que é uma coisa estática e cronificadora, você tem de estar sempre ativo, estar sempre produzindo coisas, interagindo com outras pessoas ou com a natureza, ou com o produto que você está criando" (POMPEU, 1983, p.83), fazendo com que ele possa então "conviver produtivamente com a loucura" (ibid., p.86). O autor campineiro também expõe a conveniência de nossa sociedade ao lidar com a obsessão da loucura, preservando-a e enaltecendo-a quando suas obstinações estão voltadas para o que lhe é útil (quando estava centrado intensamente em seu trabalho como jornalista editor, com a revisão de textos etc., era considerado extremamente competente e sábio, a ponto de receber prêmios de louvor); mas repelindo-a quando imposta sobre algum ato que escapa de uma pretensa normalidade. Esta constatação vai de encontro novamente com as iluminações do pensamento de Foucault, que percebe como a loucura pode ser interpretada e absorvida por uma sociedade ou civilização de diversas maneiras, por vezes bastante opostas e oportunas.

O testemunho de Pompeu se dá de forma muito pragmática, concebido por um olhar de caráter jornalístico-investigativo ou mesmo sociológico, que aparece devido ao próprio trajeto do 
autor (que foi jornalista premiado, e cursou durante alguns anos Ciências Sociais na Universidade de São Paulo). É interessante, pois apesar de parecer bem racional em certa medida, sentimos no escritor uma vontade de escapar das dialéticas, em uma posição de se manter entre e escapar ao reacionário e o revolucionário, o conservador e o progressista. Em A Greve da Rosa, por exemplo, Pompeu rompe com dualismos e gera uma força de escape a estes através da personagem principal, que em sua simplicidade e ignorância - o desconhecimento de quem fosse Hegel - se desvia à pergunta do filósofo, mostrando uma nova percepção possível:

Maria Rosa não sabia, mas um filósofo alemão chamado Hegel comparou certa vez o Ocidente com a rosa e o Oriente com a montanha. No Ocidente tínhamos tido uma sucessão de impérios, que nasciam, ascendiam, entravam em decadência e morriam, enquanto no Oriente a sociedade permanecia aparentemente a mesma através dos milênios. Mas, perguntava Hegel, que é mais belo, a rosa efêmera ou a montanha eterna? Maria Rosa responderia que olhar uma rosa dura a eternidade. (POMPEU, 1980, p.74)

Na ficção de Pompeu, os delírios são transmitidos em pacto forte com o meio social: Rosa em seu trabalho na fábrica e na relação com um líder sindical (indagamos-nos a esmo quão interessante não teria sido uma adaptação deste livro por um cineasta como Carlos Reichenbach); ou a exposição em todo um capítulo em separado da tese "O Futebol - crítica da economia política" pelo narrador de $A$ Saída do Primeiro Tempo, onde realiza uma rica analogia entre a lógica marxista e a lógica do esporte bretão, demonstrando como uma pode ser associada e aplicável a outra.

Entretanto, o texto que talvez imprima com o mais alto grau de força os delírios, a desrazão, está, para nós, em Quatro Olhos. A própria estrutura do livro parece dizer desta relação conflituosa entre o delírio e o ser, já que é dividido em três partes: Dentro (com 24 capítulos), Fora (com 4 capítulos) e De volta (com capítulo único). Este movimento, dentro-fora-de volta soa como os espaços percorridos entre as alucinações, e como cada um deles é contagiado pela condição do desvario ao ponto de se confundirem. Escrito nas duas primeiras partes em primeira pessoa, tal qual um testemunho, e na última em terceira pessoa, como se o narrador-personagem "Quatro-Olhos" estivesse "de volta" à condição de personagem literária acompanhada e observada - que não havia antes tido no livro - através de uma conversa com seu médico. O autor retrata uma série de obstinações deste personagem tanto nas relações cotidianas que trava, quanto na própria escrita: "Mais ou menos dos 16 aos 29 anos passei no mínimo três a quatro horas todos os dias, com exceção de um ou outro sábado e de certa segunda-feira, escrevendo não me lembro bem se um romance ou um livro de crônicas" (POMPEU, 1976, p.15). Ele afirma, entretanto, um desprendimento ao dizer que perdeu os originais desses escritos e que não convinha expor como isso se deu. Além de suas obstinações, seu texto é escrito de forma bastante singular, inundado por 
um delírio como que consciente e conflituoso, no qual o empírico se perde na imaginação e na farsa da literatura:

Eu colecionava multidões para pô-las por escrito. Esculpia, das massas de rostos, um, pleno em sossego, quantidades de pele em arranjo regulado, e me incriminava por fantasiar, por não descrever o vivido mas o imaginário. Magotes de ombros reflexionavam e eu queria dirigir esse movimento, simbolizá-lo no papel em ondulações firmes. Música de motores afetava os ouvidos e eu pretendia anotar a escala dos sons metálicos em cheio. Vulgarizava. (...)

Me era dado então escrever. (POMPEU, 1976, p.94)

Quão rico é este trecho no trabalho que o autor realiza no diálogo entre a literatura, as artes musicais, visuais e audiovisuais (o desenho, a fotografia ou o registro cinematográfico dos movimentos). O discernimento pouco importa, na medida em que a ficção testemunhal sobrevém em seu jogo artístico-especulativo. As ficções de Pompeu acabam por nos mostrar a carga de importância do esquecimento componente do desastre. Quando se trata de fazer emergir um inventário de lembranças, suas memórias da loucura, o autor é extremamente racional e direto, porém, quando se torna possível a ele esquecer, quando ele se põe enfim a produzir, a inventar, advém então o jogo da desrazão, com sua poeticidade irresponsável e criadora, onde não se trata mais de ser um louco ou um insensato, mas de um artista.

Todos os Cachorros são Azuis de Rodrigo de Souza Leão teve sua primeira publicação no ano de 2008, depois de alguns anos de espera pelo lançamento. À parte estas datas estanques, durante o livro do escritor carioca temos uma ausência total de fixidez no tempo e no espaço. Somos transportados durante o transcorrer do texto às mais diversas épocas do que parece ser a vida do autor, na essência autobiográfica própria a todo testemunho, de episódios de sua infância e juventude até eventos ocorridos durante algumas de suas internações na vida adulta. Os relatos da desrazão são participantes deste processo testemunhal aliado a narrativa sem gênero plenamente definível: "perturbação da medida do tempo e paradoxia desses instantes que são outros tantos tempos heterogêneos. Nem sincronia nem diacronia, uma anacronia de todos os instantes" (DERRIDA, 2004, p.87). Souza Leão está sintonizado com o que chamamos previamente - ao tratar da escrita do desastre - de fluxografia, um movimento na e da escrita que vai se construindo processualmente, sem um enredo ou definição previa em mente. Temos a impressão de - ao lermos seu texto - estarmos segurando um controle remoto, onde após cada frase, parágrafo ou capítulo mudamos de canal, em um incessante zapear, podendo inclusive acontecer de cairmos em canais que estão fora do ar, um fora do ar da linguagem e do sentido, ruídos e chiados sonoros em preto e branco: "Já falei pra esse doutorzinho que ele vai quebrar a cabeça. Vai ter um derrame sério. Eu 
blsjdsomdkm0ooooeeirrrriruuuuruuiirrriiirii” (SOUZA LEÃO, 2010, p.37). Nestas quebras ainda encontramos por vezes quase-aforismos que realizam aberturas escapes ao próprio texto, como em uma composição a que faz referência Blanchot (2007, p.13) ao afirmar que: "Cada frase é um cosmos".

Pressentimos no escritor carioca uma forma de irresponsabilidade hospitaleira da fícção, hospitaleira pois somos convidados a adentrar experiências da vida do autor, por vezes bastante íntimas e confessionais (é sabido que ele fora diagnosticado com esquizofrenia, e que realmente passou por algumas internações em hospitais psiquiátricos), e irresponsável, pois resguarda o teor de manuseio da ficção que nunca nos é possível precisar, o testemunho irreal, a paixão da literatura: nela tudo acaba por acontecer, mesmo sem nunca ter tido lugar. Talvez só na literatura e na arte é que exista este local onde ao mentir, se está sendo honesto - torção do pensamento puramente blanchotiana. Diferentemente dos autores trabalhados anteriormente - todos escritores do século XX - já não encontramos no escritor carioca o relato cerrado e separado em diários ou anotações, sua escrita se dá na mistura direta entre testemunho e ficção, estando ambas perdidamente espelhadas em um só texto.

O estado de delírio, do que pode carregar a desrazão está em Souza Leão de forma bastante semelhante, em consonância com Maura Lopes Cançado, com o elemento da vigília no desastre de Blanchot, condição de indiscernibilidade entre sonho e realidade, o escritor como um insone do dia, como se para ele não houvesse uma separação entre dormir e acordar. São os tempos de ociosidade, entregues ao vazio, que acabam por fornecer as matérias da força de alucinação e criação. A dúvida e a imprecisão são também novamente protagonistas, como que a partir de uma das flechas disparadas por Nietzsche, arremessadas mais adiante por Blanchot e recepcionadas pelo escritor carioca, que diz em outro de seus relatos: "Eu não peço que ninguém vá acreditando na veracidade de minhas palavras. Peço que duvidem de mim" (SOUZA LEÃO, 2011, p.17). O próprio caráter autobiográfico, que inegavelmente existe, não escapa assim dos tremores de um terreno de uma escrita do desastre, de imprecisão e estranheza.

Os personagens de uma pseudo-trama que por vezes parece ocupar Todos os Cachorros são Azuis são figuras importantes para a confecção de algumas leituras. Além das já mencionadas personagens literárias e amigas imaginárias do narrador/autor - Baudelaire e Rimbaud - temos os próprios loucos com os quais ele convive em suas internações, e que também se tornam matéria para o jogo testemunhal. Uma destas personagens, nomeado como o "Temível Louco" é assassinado dentro do hospital, sem que nada garanta ao leitor que o fato tenha realmente acontecido, mas isto não importa, já que a força deste acontecimento opera no leve desvio que imprime na narrativa, que toma contornos de romance policial durante um capítulo, e em algumas frases e parágrafos do 
restante do texto.

Assim como Renato Pompeu, na ideia de uma visão mais panorâmica do que é tido e separado pelo meio social como útil ou inútil, Souza Leão escreve sobre um dos internos que observa:

Eu sempre dava um cigarro para um louco que, na hora do almoço, dava cabeçada nas paredes. Imagina se esse doido fosse jogador de futebol. A cabeçada dele ia ser poderosa. Acostumado a cabecear paredes, ele ia estourar todas as bolas que cabeceasse. Quem sabe a seleção brasileira não o convocaria? (SOUZA LEÃO, 2010, p.21)

Segundo Jacques Derrida, a figura do narrador nos casos do testemunho, e isto fica mais claro no texto de Souza Leão, transita por uma tríade, formada pela personagem, pelo narrador e pelo autor. Adentrando o campo da literatura o sujeito acaba dividido nesta forma tripartite, no hesitar entre três pontes que se confundem, assim como nos casos dos pontos dúbios (verdade ou farsa, gênero ou hibridismo). A distinção entre estas três partes se torna então insípida, entrando em questão mais uma vez a carga de paixão, de intensidade que pode haver em um texto. Diz o filósofo franco-argelino (2004, p.76):

O deslizar destes três quer dizer metonímicos, o jogo destes três eus, é uma paixão da literatura como paixão da morte e compaixão entre estas três instâncias (autor, narrador, personagem), é a paixão em literatura, o que sofre, padece, tolera e cultiva o limite perverso entre Dichtung und Wahrheit.

Observamos finalmente, através destes parágrafos no qual nos debruçamos em cada um dos autores aqui propostos para pesquisa, o próprio movimento no qual configurou a literatura no século XX até a chegada no contemporâneo. Os níveis de costura entre testemunho e ficção, entre a obra literária e a realidade, se encaminharam de forma crescente através dos autores (por isso talvez faça sentido a abordagem de alguma maneira cronológica) atingindo então um maior grau de mistura com Rodrigo de Souza Leão, que parece se furtar - de maneira ainda mais intensa que nos outros casos - à desrazão, à entrega ao delírio escritural, isto já no século XXI, portanto, em um autor dito contemporâneo. 


\subsection{Uma língua-outra: todog}

Ao final do terceiro capitulo de Todos os Cachorros são Azuis de Rodrigo de Souza Leão, temos a abertura de um epílogo final, intitulado "[Do gr. epílogos]". Ao relatar brevemente o retorno ao lar após mais uma internação, por meio de uma escrita construída através de pequenos blocos de texto, o autor-narrador-personagem afirma um dia ter acordado de súbito, ouvindo o eco de uma palavra: Todog. Da insistente repetição de um sonho que trazia ecos de palavras diferentes e desconhecidas, absorvidas e como que sendo transmissoras de alguma mensagem especial, celestial ou extraterrena, o narrador publica um recado, pelos classificados de um jornal, contando sobre esta manifestação. A partir deste anúncio, ele passa a receber em sua casa desconhecidos que dizem ter sido tocados por sua mensagem, e então iniciam reuniões - batizadas de Todog - para conversar a respeito do fenômeno. Esta palavra inicia um curso de significação de duas entradas: $1^{\mathrm{a}}$ a da criação de uma espécie de seita, da qual o narrador passa a ser considerado líder; $2^{\mathrm{a}}$ a de uma nova língua, de uma inédita forma de comunicação idiomática dita universal. O rumor de sons, de palavras sem significado, de murmúrios vindos não se sabe bem da onde (do sonho? Da desrazão? De um alémmundo?) desatam a união entre pessoas.

Nas características deste grupo - ou poderíamos dizer comunidade - criada pela personagem, são inseridas inúmeras ocorrências de reuniões cada vez mais comuns no contemporâneo, podendo estas serem de caráter religioso, ambiental, político etc (tal qual em uma comunidade presentificada). Do culto ao Todog nos interessa pensar de que forma este novo código de linguagem se constrói. Segundo Peter Pál Pelbart, ao analisar um texto de Foucault a partir das experiências com os jogos de linguagem realizados por Jean-Pierre Brisset, há duas vias por onde se pode vislumbrar os tremores os quais a linguagem pode enfrentar. Diz o filósofo:

(...) a linguagem se nos apresenta como uma totalidade dada e estruturada, em que dificilmente percebemos o tremor de uma origem ou de um exterior. Michel Foucault entendeu, porém, que é através desse tremor que a linguagem pode se colocar em xeque (com o que ela se avizinha da loucura) e estudou-a sob este aspecto nas duas direções mencionadas acima, a da origem e a do exterior. (PELBART, 2009, p.97)

Diferentemente de Brisset que desmantela a língua francesa em seus significados gerando novos sentidos para ela, principalmente através do jogo da sonoridade e do ritmo, o todog se foca mais nos dados de uma origem. Seus poderes de designação (expressão definida por Foucault) se mantém em aberto, no todog não há códigos específicos a serem decifrados para que a comunicação 
possa ser efetivada, seus significados são livres para a interpretação dos seres comunicantes ou em diálogo, e todos parecem entender o que o outro diz: "Todog olambolic Todog. O que significa? Não costumamos traduzir. Ou as palavras penetram em você ou não. Xuma me entende, não é Xuma? Sim, Todog” (SOUZA LEÃO, 2010, p.77). Em uma estranha confiabilidade que parece existir entre os seres pertencentes ao grupo, as coisas são sempre ditas e imediatamente absorvidas através de uma pretensa semiótica da sensibilidade, baseadas em intuições.

Nesta rejeição, ou negação de uma tradução, o indivíduo se ausenta da responsabilidade de gerar um significado que fecharia a compreensão. Em Brisset, há um quebra-cabeça múltiplo a ser decifrado, já na língua criada por Souza Leão este quebra-cabeça é livre, o desenho que ele revela é próprio a cada ser, e o entendimento se dá em outro campo, como que em um pacto ao mesmo tempo subjetivo (pois há um emissor que "recebe" as palavras e as emite) e universal entre os seres. Nesta abertura que não quer dizer todo e qualquer sentido, posto que os indivíduos se comunicam e dizem se compreenderem, há algo que fala mais do que a codificação e a descodificação de signos verbais. O todog funciona então exatamente como uma língua da loucura, pois:

\begin{abstract}
A loucura não tem um sentido oculto. Ela tem uma reserva de sentido, o que deve ser entendido de forma particular: não como provisão, estoque resguardado à espera de um decifrador, mas como retenção e suspensão do sentido, como criação de um vazio onde possa se alojar não um, mas vários e diferentes sentidos (PELBART, 2009, p.102)
\end{abstract}

Nesta reserva de sentido, de um vazio que não está dado ao nada, mas à apreensão de um significado particular, é que habita o chamado todog. Em filigranas, na fronteira sempre tênue entre o perigo da compreensão e o da não-compreensão é que este novo idioma se encontra. Mas até onde está dito por este personagem-autor-narrador, o desentendimento acaba por nunca acontecer. O entrave na comunicação, que é uma das possibilidades dos idiomas vigentes no mundo, já que alguém pode querer dizer alguma coisa e o outro não compreender por uma série de fatores (vocabulário restrito, não-compreensão de uma lógica, desconhecimento de um idioma etc.) não ocorre. Trata-se de uma língua que opera em outro nível, que não o da funcionalidade comunicativa. Diríamos que ela é portadora de uma espécie de linguagem mística - no rastro de uma sensibilidade invisível, a ser captada -, pois sua compreensão (talvez seja até complexo usar esta palavra nesse caso, mas admitimos e tomamos o risco) se dá de outra forma, em uma lógica da intuição pressentida e certeira, onde todos se entendem, apesar de falarem cada um a sua maneira: "Havia uma liga que congregava todos os seres do universo. Mas cada um falava a sua língua. $\mathrm{K} \mathrm{d}$ pocua besourfez biologic Todog" (SOUZA LEÃO, 2010, p.69). Esta língua se aproxima talvez de uma das linguagens excluídas, tal qual definida por Michel Foucault, a partir das criações resultantes da 
loucura em contato com a linguagem. Nesta linguagem que é excluída, ejetada, podemos observar uma aproximação de elementos do desastre, como no caso do silêncio que porta cada palavra. Essa exclusão faz referência ainda mais uma vez a um temor humano de deixar jorrar pela fala e pela escrita aquilo que lhe causa estranheza, que busca controlar por não saber como se portar a partir destas provocações. Assim como na linguagem excluída, no todog

Pouco importam, então, o que se diz em uma semelhante linguagem e as significações que aí são liberadas. É essa liberação obscura e central da palavra no coração dela própria, sua fuga incontrolável para uma moradia sempre sem luz, que nenhuma cultura pode aceitar imediatamente. Não é em seu sentido, não em sua matéria verbal, mas em seu jogo é que uma tal palavra é transgressiva. (FOUCAULT, 2006, p.215)

À língua criada por Souza Leão pode ser associada uma forma de comunicação em multiplicidade una ou subjetividade múltipla, próxima ao conceito de comunidade proposta por Nancy, Blanchot e Agamben; e ainda de uma impessoalidade neutra, pois na medida em que alguém pode tudo ou nada dizer, ele passa a não forçosamente emitir uma fala de si, mas também a de um outro, improvável e impensado. Aí se encontra uma forma na qual a noção de esquizofrenia pode habitar a língua: o ser é desdobrado, multiplicado, esvaziado na confusão, no delírio de uma fala.

Gilles Deleuze analisou certa vez os procedimentos linguísticos operados pelo escritor Louis Wolfson por meio de combinações fonéticas e sonoras que realizam desvios na língua materna levando-a para outras regiões idiomáticas. Deste movimento que chamou de uma esquizolíngua, o autor estadunidense se aproximou de dois outros escritores: do já mencionado Jean-Pierre Brisset e do poeta Raymond Roussel. Diz Deleuze (1997, p.19): "Nos três casos extrai-se da língua materna uma espécie de língua estrangeira, sob a condição de os sons ou fonemas continuarem sempre semelhantes". O procedimento (se é que podemos chegar a chamá-lo assim) de Souza Leão não recai necessariamente na semelhança com sons ou fonemas da língua portuguesa, que até ocorrem, mas por vezes também acontecem com sonoridades de outros idiomas como no caso do latim, ou mesmo com o uso de onomatopeias. Acreditamos então que nos momentos em que há semelhanças com línguas existentes, trata-se de coincidências, de fortuitos encontros fonéticos. Os códigos linguísticos são para ele secundários. A abertura para um acaso, para um livre balbuciar, como em um jogo quase automático da fala é o que parece mais notório na língua todog. Sua atração se fixa mais em questões de entendimento semântico, posteriores ao proferir de uma mensagem, do que na construção fonética. Os códigos linguísticos habitam, portanto, para o escritor carioca, uma "(...) região branca da auto-implicação onde nada é dito" (FOUCAULT, 2006, p.217). Há assim a 
composição de uma semântica que é dotada de uma vizinhança que extrapola territórios e fronteiras nacionais, por isso é que talvez o todog seja a língua mais estrangeira possível, extraída de um vai e vem exterior que não se pode situar ou identificar, algo cósmico, interstelar.

A língua todog se avizinha ainda do delírio e da desrazão, pois a cada instante em que é proferida inventa para si uma nova forma de expressão idiomática: "Ao criar a língua a cada fala, a loucura diz a possibilidade infinita da criação de línguas, e na enunciação e criação de um código, por mais efêmero e indecifrável que ele seja (...)” (PELBART, 2009, p.102). Por meio de uma relação sem gramática, as palavras podem trabalhar sem o fardo classificador e organizador de suas operações, sem uma lógica aparente, em um processo de organização desordenada - tal qual o fragmento - ao compor a escrita e o pensar particionados, deixando assim a linguagem como que completamente desnuda e aberta a uma livre composição.

Aí reside um ponto nevrálgico nesta criação de Souza Leão: através da invenção do Todog, ele acaba por atacar a base mais firme da possibilidade de comunicação entre os seres humanos, pois em nossa civilização (pelo menos por ora), a linguagem é a mediadora principal das relações. A língua talvez seja a forma mais direta e portadora de maior fixidez na construção do próprio indivíduo já que é através, por exemplo, de um idioma, que somos definidos em grande medida sobretudo culturalmente. Criar uma nova língua é produzir todo um novo universo. Atacá-la, ao mesmo tempo, talvez seja a maneira mais audaz de delírio escritural, pois violenta o entendimento considerado em sua fundação dita mais sólida.

Retornando finalmente ao epílogo/capítulo, com o passar do tempo o grupo Todog cresce vertiginosamente se transformando em uma efetiva comunidade - são criados campings para reunir seus integrantes. A compreensão desta forma de agrupamento diz diretamente da relação entre o grupo e sua língua: "Pois a comunidade não é nada além do que a comunicação de 'seres singulares' separados, que só existem como tal através da comunicação" (NANCY, 1999, p.256), sendo esta uma comunicação bastante peculiar, como vimos. A analogia do narrador com um líder religioso ou unívoca figura de comando principal se torna cada vez mais presente (ele começa a proferir discursos em Todog para crescentes multidões) até o dia em que policiais o levam para ser enclausurado - tal qual em uma prisão - em um hospital psiquiátrico. Atirado violentamente em face das instituições de controle e disciplina de nossa sociedade, o narrador é condenado por “incitação popular”. O desenlace, se é que assim pode ser denominado, de mais uma das pseudotramas que engendra Souza Leão, ocorre quando a seita Todog acaba sendo incorporada à forma institucional, entrando em condição de legalidade e acabando por ser considerada como religião, baseada na liberdade de culto. O final abrupto desta narrativa se dá quando um fanático fundamentalista Todog assassina o líder com dois tiros - as associações aqui são evidentemente 
múltiplas com figuras públicas mitigadas, cultuadas e que sofreram da mesma agressão, como por exemplo John Lennon e John Kennedy. Daí em diante a história se esvanece como uma fagulha, ou como se alguém houvesse apertado de uma só vez e ao mesmo tempo inúmeros botões, talvez sem querer, de um controle remoto literário.

Princilimpimpotus todog todog todog e grilos e eletrodos e casa devastada e cachorro azul e bolo de laranja e policiais B e Lembra-vovó e eu vou pra Paracambi se eu não comer, vou pro caju e Procurador brilhantina e Xuma e agora o agora. Dia D. Hora H. A bomba e seu cogumelo de endorfinas explodem em meu corpo baionetado e com a química dos anjos. A ogiva. E depois, Rodrigo? O que fez do depois? Aqui onde as nuvens se encontram, levo sempre um choque maior do que os que levei no hospício. (SOUZA LEÃO, 2010, p.78) 


$$
\begin{aligned}
& 6 \\
& 5 \\
& 5
\end{aligned}
$$

4

$$
\text { Quarto Capítulo/Conclusão }
$$

[ Fukushima mon amour: um upgrade atômico ]

$$
\begin{aligned}
& 65 \\
& 3,9
\end{aligned}
$$


Buscamos no capítulo anterior salientar a força de uma literatura da desrazão, que operou como fulcro vivo da escrita do desastre, dentro de parte da literatura brasileira. Permeados pela ideia de uma comunidade do pensamento, ou ainda de um comunismo literário, perseguimos composições em literatura pautadas pelo testemunho autobiográfico que, em nossa visão, romperam de forma crescente, no passar do tempo, com a distinção mesmo de biografismos e da garantia da pura transposição memorialista. Vimos como, a partir do início do século XX com Lima Barreto até o início do século XXI com Rodrigo de Souza Leão, os aspectos da distinção entre real e ilusão, testemunho e ficção, e o de diversas outras instâncias (como as de gênero literário) foram sendo cada vez mais embaçadas, enevoadas a ponto da indiscernibilidade. Nestes relatos, uma primeira pessoa vai sendo aos poucos corroída, alterada e dinamitada ao ponto da perda de referências pessoais.

Ora, esta talvez seja a potência maior do desastre blanchotiano: ele é o movimento impessoal, imperceptível e invisível que, lento e veloz; certeiro e sem direção, incorpora em tudo o que nos soa estranho, deixando-nos estarrecidos. Uma escrita do desatino parece então se firmar a partir do que o desastre mais anseia, sem desejo posto que sem ego, - o escritor finalmente funcionando como veículo, como mediador dos elementos de composição de uma alquimia literária que entram em ebulição, já não mais buscando colocar em rédeas, domar a linguagem. Sem a garantia de posições hierárquicas, não há mais um amo ou um servo. Não sendo mais um agente disciplinador e controlador, o escritor pode então trazer para a literatura e para o pensamento a voz neutra (ninguém fala), da passividade (ninguém age) e do esquecimento (ninguém lembra).

$\mathrm{Na}$ liberação de forças inconscientes da desrazão fragmentária nenhum segredo é revelado, e o enigma maior está aí. Silenciosas, as potências de uma comunidade nunca reunida fisicamente se espalham, chegando ao local aonde escrever é essa “(...) morte diferida: desastre” (BLANCHOT, 1980, p.220).

O livro que se posicionou como ponte principal a esta pesquisa, como passagem para atravessamentos - da questão do fragmento e posteriormente do pensamento da comunidade e da desrazão - é texto infinito, um livro sempre por vir. Ao retornarmos e consultarmos, pelos mais diversos motivos, L'Écriture du Désastre, a sensação permeada era a de que estávamos lendo algo que preservava seu estado de ineditismo, de desconhecimento, mantendo-se como que incólume, porém com a impressão de nos soar familiar. Este livro de Maurice Blanchot se assemelha com uma mina de metais nobres que, de tempos em tempos, parece se reinventar, se refundar, na produção como que miraculosa - de novas preciosidades. Ali, o pensador francês parece dizer bastante do contemporâneo, pois lida com limiares, se portando como um propulsor de misturas, como, por 
exemplo, na confusão de gêneros, expondo talvez o fator desnecessário de categorizações e engessamentos. Sua trajetória aponta para a liberação do inumano, no sentido daquilo que não se enquadra mais em humanismos de aporte puramente racional.

Uma breve digressão metodológica: queríamos, durante todo o período de estudo e escrita, por meio de intervalos irregulares, nos trair, nos surpreender - o que foi certamente fonte de momentos de tensão e de aporias. Não nos furtamos a um olhar voltado ao descobrimento e à utilização de aspectos novos e inesperados que foram aparecendo, mesmo impensados na confecção do projeto, e que acabaram por desmontar e remodelar o que havíamos previamente pensado (esse foi o caso ao lidarmos com o conceito de comunidade, que acabou por alterar nossa percepção da desrazão, amplificando o recorte proposto antes da efetiva execução da escrita na pesquisa). Compreendemos que nesta constante reinvenção, corríamos o perigo de talvez perder de vista importantes questões, mas mantivemos em perspectiva a ideia de que seria mais rico um trabalho que aceitasse e optasse por correr riscos - como se, seguindo a sugestão do desastre, deixássemos a pesquisa falar um pouco por si, lançando ela mesma os dados do acaso.

Gostaríamos de considerar este trecho final como uma espécie de fecho ou conclusão apenas na medida em que encerra a digitação de um texto (a exemplo de Bartleby), mas que não interrompe um pensamento e uma escrita. Enfim, mas não por fim, este trabalho pretende ser considerado - pois é ele mesmo quem parece o dizer - como algo que subjaz ao impossível.

Respeitando e seguindo a linha do recorte produzido anteriormente nesta pesquisa, para ser mais exato no início do último subcapítulo da Corporificação do Desastre - segundo a sentença de Blanchot na qual se afirma a necessidade de dar corpo ao invés de sentido ao desastre - visamos continuar a perseguir os traços de uma tensão ou perigo atômico, do abalo nuclear como corpo do desastre que incidiu em uma quebra na história e em seus fatores. Dada a identificação da marca de uma fissura atômico-artística realizada na metade do século XX por Hiroshima mon amour, e a percepção de um suposto início do fim da história a partir daí - a história pensada como uma grande narrativa esgotada e transitória - abrem-se vãos para a aparição da novidade do que é chamado de tempos trans-históricos, ou seja, de pulsões que escapam à história, aquelas em que, no avanço das dissoluções promovidas pelo desastre, a própria noção de história como (de)marcação temporal e humana vai perdendo suas definições e todo um novo campo de potencialidades passa a ser exposto - por exemplo a arte, a filosofia, a literatura, aumentando ainda mais seus movimentos de simbiose. O desastre (e o caso nuclear é exemplo disto) se configura ainda como procedimento temporal 
sempre ambíguo que - apesar de apontar para uma eterna iminência - já está instalado.

Enxergamos então a possibilidade de produzir uma peça artística que gerasse uma força próxima e análoga ao trabalhado no desenvolver do terceiro capítulo, em uma trans-história permeada pelo testemunho e a desrazão, que estivesse em sintonia e trouxesse

O inusitado, o novo, porque ele não pode tomar lugar na história, é também aquilo que há de mais antigo, alguma coisa de não histórico ao qual somos chamados a responder como se fosse o impossível, o invisível, aquilo que desde sempre tem desaparecido sob os escombros. (BLANCHOT, 1980, p.63/64)

Em maio de 2014 demos vida ao material poético-audiovisual Fukushima mon amour que possuía em sua composição elementos textuais (oralizações), visuais (videografias) e sonoros (audiosensitivos). A partir dos eventos ocorridos no início deste século na cidade de Fukushima, no Japão, onde ocorreu o vazamento de material radioativo de uma usina de produção de energia nuclear para o lençol freático que abastecia e habitava sob toda a cidade ${ }^{24}$, percebemos a oportunidade de realizar uma forma de releitura do ocorrido no final da segunda guerra mundial, dada a repetição do desastre atômico, e como as diferenças entre os dois casos espelhavam aspectos das mudanças tramitadas com o passar das décadas que separaram os eventos. Destas apreciações é que surgiu o estímulo para a produção do texto a ser lido e do material audiovisual composto.

Cabe, entretanto, salientar que não se trata de uma simples reformulação ou repaginação a partir do evento de Hiroshima, já que o ocorrido quase 70 anos depois possui contornos bastante singulares. Acreditamos assim que se trata muito mais de um atravessamento, de um radical upgrade. Notamos como uma diferença crucial entre os dois acontecimentos está em relação direta com os processos de marcações estanques das duas grandes guerras do século XX e o gerar de múltiplas crises e tensões locais e globais no século XXI (aspecto especulado na abertura do terceiro capítulo). Em 1945, a bomba enviada pelos EUA para Hiroshima se impôs em grande escala e de uma só vez - em um movimento direto vindo de cima, um nefasto míssil-cometa desabando do ar para a terra. Já em 2011, na cidade de Fukushima, um desastre natural, um tsunami, foi responsável pela danificação de parte da usina nuclear da cidade, sendo então liberado material radioativo para o lençol freático. Neste caso, a contaminação, o ataque sem rosto, veio de forma sorrateira, paulatina e subterrânea, tal qual os elementos do desastre. Em um movimento reverso ao de 45, a contaminação em Fukushima se deu da terra para o ar. Isto entra em consonância com o fato de, nos dias atuais, vivermos processos como que diluídos, mas tão letais, ou mais, que aqueles plenamente captáveis aos olhos. Estes processos se dão também nas artes, onde as

24 Para maiores informações e aprofundamentos no caso, sugerimos o acesso ao endereço virtual: http://www2.uol.com.br/sciam/artigos/resumo_de_fatos_sobre_a_radiacao_em fukushima.html 
mudanças já não são tão diretas e radicais, mas que, no entanto, continuam a existir.

Vejamos agora alguns dos procedimentos adotados para a construção da apresentação por nós realizada: se faz presente nela a utilização de citações, o usurpar de textos externos que em composição com outros blocos textuais ganham contornos muitas vezes diferentes daqueles originais. Vislumbrando a própria escrita do desastre - portadora de seus elementos e de um fazer fragmentário sempre em atuação - e as manifestações produzidas nos últimos anos alinhados com estas noções (como exemplo podemos citar novamente o trabalho do escritor espanhol Agustín Fernandéz Mallo), buscamos de alguma maneira materializar, mesmo que por vultos, pressentimentos e evocações, dados do desastre blanchotiano. A voz que se ouve na oralização do texto está no rastro do neutro e da passividade de uma fala que soa a partir de um lugar indiscernível, onde uma poeticidade é força motriz para sua emissão, sem que se possa fixar claramente a imagem de um ser, de seu rosto. Na fuga de humanismos, não se tratava de denunciar a penúria do humano, mas de atentar inventivamente para algumas de suas tolas atuações no mundo. Na manutenção de uma aura ritualística buscamos os dados de uma desrazão que espantasse a piedade e o puro teor apocalíptico que o tema pode suscitar. As imagens e os sons apresentados trazem a força de composição do cinema e da música em sintonia com estas proposições.

Tentamos ainda nuançar a ideia de desastre como pura e simples catástrofe causada por um Humano sempre predador e maléfico. Mesmo colocando a perspectiva do ser humano e do acidente atômico como produtor de traumas e tensões para o ecossistema, nosso foco se concentrou, em maior escala, na proposição e no oferecimento de experiências diversas e estranhas quando pensado o atômico - como a ideia de uma psicodelia ou lisergia nuclear - indo além de esferas já em voga desde o século XX, e que correm, elas mesmas, o risco de recair sobre humanismos empobrecedores para a arte.

Outras experimentações artísticas parecem ainda dialogar em certa medida com a proposta de Fukushima mon amour, ao menos quanto ao apontamento de dados de transformação e amplificação do campo artístico através de desenvolvimentos e abalos científicos ocorridos após os anos 80 do século XX e a entrada no século XXI. Dois casos nos chamam particularmente a atenção: $1^{\mathrm{o}}$ o trabalho do artista multimídia Eduardo Kac, conceituador de uma bioarte na qual se torna possível instaurar a arte transgênica, que, fazendo uso da engenharia genética, opera na criação de novos seres vivos portadores de movimentos que recompõem a própria ideia de arte, além do levantamento de discussões e colocação de questões éticas e simbólicas para a compreensão da abertura de novos campos na ciência ${ }^{25} ; 2^{\circ}$ os atos e as palavras do escritor Márcio-

\footnotetext{
${ }^{25}$ Apesar de nossa criação não se enquadrar propriamente na ideia de "arte dialógica", bastante valorizada por Kac apoiado em autores como Martin Buber e Mikhail Bakhtin, acreditamos que o apontamento de questões de tensão e ética científica e das mudanças na invenção artística e estética, já constrói uma ponte relacional entre os trabalhos.
} 
André autoproclamado o primeiro poeta nuclear por ter, em uma arriscada visita aos terrenos da cidade fantasma de Pripyat, Ucrânia, contaminados no ano de 1986 pela eliminação de material radioativo proveniente da usina de Chernobyl, declamado poemas seus e de outros autores (além de abandonar livros no local) em frente ao antigo Ministério da Cultura daquele país, no ano de 2007. Este ato foi nomeado pelo poeta como a primeira "Conferência Poético-Radioativa de um homem só".

Algo parece advir - uma tensão, uma iminência - da operação de troca que pode haver entre a impostação da voz poética, de seu ressoar, com as energias infecciosas que continuam a se espalhar pelo terreno atingido. Incidem, pois, sobre o trabalho destes autores os elementos do desastre, proeminentes de fragmentações e de novas formas combinatórias de arte aderidas ao contemporâneo (a multiplicidade das vias de atuação). Na esteira dos corpos materializados na mediação do conceito de Blanchot, observamos como suas forças são potencializadas ainda pela ideia de comunidade, com as flechas em questão - as setas do desastre - sendo lançadas pelo pensador francês, e como que atingindo e se reprojetando nas passagens (nunca iguais e sempre remodeladas) por Kac, Márcio-André e Mallo, até a chegada em Fukushima mon amour; e da desrazão, principalmente no que tange a ideia do desobramento, da experiência-limite que faz com que algo escape às formas meramente empíricas e racionais, ao mesmo tempo em que se materializa, tendo lugar em um espaço-tempo performático.

Indo de encontro ao caráter plural no qual estas peças artísticas podem figurar, além da apresentação realizada ao vivo - passível de improvisação, acasos e erros das mais diversas ordens - optamos por garantir uma força hipertextual ao escrito composto como fonte de leitura durante a execução dos áudios e vídeos. Por isso, além da possibilidade de se ater a apresentação in loco, decidimos por oferecer ao espectador/ouvinte/leitor o acesso a este trabalho em um endereço virtual, localizado em: https://vimeo.com/122833781.

A seguir reproduzimos - como mote final - o texto criado para a leitura poético-audiovisual, como arquivo a ser baixado, download para um desastre atômico-artístico: Fukushima, mon amour. 


\section{“FU-KU-SHI-MA}

Fukushima, mon amour

Foram despejados os últimos dejetos nas águas. 0s restos remanescentes das ruínas em abandono. Silêncio completo silêncio completo.

\section{Espectros...}

0 Testemunho é um acontecimento.

Relatar... Relatar... Relatar...

Venda de telefones celulares proibidas para crianças

“Desde 1 de Março de 2014, os celulares que são concebidos especialmente para as crianças já não poderão ser introduzidos no mercado belga. Trata-se de telefones móveis personalizados e adequados para crianças menores de 7 anos de idade. A partir desta data, nenhuma publicidade poderá ser feita para uso do telefone celular entre a mesma faixa etária. A Taxa de Absorção Específica (SAR) passa a se tornar informação obrigatória ao consumidor. A partir de agora, quando comprar um novo telefone celular, será possível escolher o novo dispositivo com base na taxa de absorção específica. "

Texto retirado de notícia de jornal

Caiu o mundo.

Corpos se derretem, se dissolvem com a espessura do mel.

Os objetos são os novos seres viventes. 
0 radioativo é psicodélico.

Fractais contaminados provocam arrepios através do olhar.

"Eu consigo sentir tanta alegria... é quase igual... quando eu era criança, a visita para os mortos era um passeio lindo para mim, lindo. Eu nunca ficava triste quando visitava os mortos, eu me dizia: eles não sentem mais nada, e eu estou aqui respirando e dentro de mim havia um frescor, eu respirava várias vezes, sempre repetindo: eu estou viva, eu estou viva... e tudo em volta de mim era vida, apesar dos mortos..." Hilda Hilst em As Aves da Noite

Fukushima está em todo lugar!” 


\section{BIBLIOGRAFIA}

AGAMBEN, Giorgio. A Comunidade que Vem. Tradução de António Guerreiro. Lisboa: Editoral Presença, 1993.

. O que é o Contemporâneo? e outros ensaios. Tradução de Vinicius Nicastro

Honesko. Chapecó: Argos. 2010.

ALVIM, Luiza; OLIVEIRA, Nilson; QUEIROZ, Andre (orgs.). Apenas Blanchot! Rio de Janeiro: Pazulin, 2008.

ANTONIOLI, Manola. Nietzsche et Blanchot: Parole de fragment. In: HOPPENOT, Érik e MILON,

Alain (orgs.). Maurice Blanchot et la philosophie. Paris: Presses Universitaires de Paris Ouest, v.1, 2010, p.103-110.

BARRENTO, João. O Mundo está cheio de Deuses - crise e crítica do contemporâneo. Lisboa: Assírio \& Alvim, 2011.

BARRETO, Lima. Diário do Hospício e O Cemitério dos Vivos. São Paulo: Cosac Naify, 2010.

BECKETT, Samuel. En attendant Godot. Paris: Les Éditions de Minuit, 2012.

BIDENT, Christophe. Maurice Blanchot, partenaire invisible. Seyssel: Champ Vallon, 1998.

BLANCHOT, Maurice. L'Écriture du Désatre. Paris: Gallimard, 1980.

. A Conversa Infinita 1 - A palavra plural. Tradução de Aurélio Guerra Neto.

São Paulo: Escuta, 2001.

. A Conversa Infinita 2 - A experiência limite. Tradução de João Moura Jr.

São Paulo: Escuta, 2007.

. A Conversa Infinita 3 - A ausência de livro. Tradução de João Moura Jr. São

Paulo: Escuta, 2010.

. A Parte do Fogo. Tradução de Ana Maria Scherer. Rio de Janeiro: Rocco,

1997. 
. A Comunidade Inconfessável. Tradução de Eclair Antônio Almeida Filho.

Brasília: Editora Universidade de Brasília; São Paulo: Lumme Editor, 2013.

. L'Instant de ma mort. Paris: Gallimard, 2002.

. Pena de Morte. Tradução de Ana Maria de Alencar. Rio de Janeiro: Imago,

1991.

. The Writing of Disaster. Tradução de Ann Smock. Nebraska: University of

Nebraska Press, 1986.

. Une voix venue d'ailleurs. Paris: Gallimard, 2002.

BORNHEIN, Gerd. Aspectos Filosóficos do Romantismo. Porto Alegre: Cadernos do Rio Grande, 1959.

BRANCO, Lúcia Castello; BARBOSA, Márcio Venício; SILVA, Sérgio Antônio (orgs.). Maurice Blanchot. São Paulo: Annablume, 2004.

CANÇADO, Maura Lopes. Hospício é Deus - Diário I. São Paulo: Círculo do Livro, 1988.

COLLIN, Françoise. Maurice Blanchot et la question de l'écriture. Paris: Gallimard, 1986.

CUNHA, Graciane. A urgência do ser: uma análise da escrita autobiográfica em Todos os Cachorros são Azuis e Hospício é Deus. Disponível em: http://www.rodrigodesouzaleao.com.br/files/hor/sobre ele/sobre ele43.htm. Acesso em 30 Mar. 2015.

DANTO, Arthur C. Após o Fim da Arte: A Arte Contemporânea e os Limites da História. Tradução de Saulo Krieger. São Paulo: Odysseus Editora, 2006.

DE PAULA, José Agrippino. Lugar Público. São Paulo: Papagaio, 2004.

DELEUZE, Gilles. Crítica e Clínica. Tradução de Peter Pál Pelbart. São Paulo: Ed. 34, 1997.

. Foucault. Tradução de Claudia Sant'Anna. São Paulo: Brasiliense, 2005.

. Lógica do Sentido. Tradução de Luiz Roberto Salinas Fortes. São Paulo:

Perspectiva, 1974.

. Nietzsche e a Filosofia. Tradução de Edmundo Fernandes Dias e Ruth Joffily Dias. Rio de Janeiro: Editora Rio, 1976. 
. Sobre o Teatro. Trad. de Fátima Saadi, Ovídio de Abreu e Roberto Machado.

Rio de Janeiro: Jorge Zahar Ed., 2010.

DERRIDA, Jacques. Morada - Maurice Blanchot. Tradução de Silvina Rodrigues Lopes. Lisboa: Vendaval, 2004.

$$
\text { Blanchot. Disponível }
$$

em:

http://www.jacquesderrida.com.ar/frances/blanchot.htm. Acesso em 08 Abr. 2014.

DUBOIS, Philippe. Cinema, vídeo, Godard. Tradução de Mateus Araújo Silva. São Paulo: Cosac Naify, 2004.

DURAS, Marguerite. Hiroshima Mon Amour. Paris: Gallimard, 2010.

FAWCETT, Fausto. Favelost: (the book). São Paulo: Martins Editora, 2012.

FOUCAULT, Michel. As Palavras e as Coisas. Tradução de Salma Tannus Muchail. São Paulo: Martins Fontes, 2007.

. História da Loucura. Tradução de Teixeira Coelho. São Paulo: Perspectiva, 2007.

- A Loucura, a Ausência da Obra. In: Problematização do Sujeito: Psicologia, Psiquiatria e Psicanálise. Tradução de Vera Lucia Avellar Ribeiro. 2ed. Rio de Janeiro: Forense Universitária, 2006, v.1, p.210-219.

. O Pensamento do Exterior. In: Estética: literatura e pintura, música e cinema.

Tradução de Inês Autran Dourado Barbosa. 1ed. Rio de Janeiro: Forense Universitária, 2009, v.1, p.219242.

GARRIGUES, Pierre. Poétiques du Fragment. Paris: Klincksieck, 1995.

HARTMANN, Anna. A arte da linguagem e do estilo em Nietzsche. Ideação, Feira de Santana, n. 12, p.25-44, Jul./Dez. 2003.

. O Duplo Olhar: escrita e filosofia em Nietzsche. 1991. 127f. Dissertação (Mestrado em Filosofia) - Pontifícia Universidade Católica do Rio de Janeiro, Rio de Janeiro, 1991.

HEJINIAN, Lyn. Minha Vida. Tradução de Maurício Salles Vasconcelos. São Paulo: Dobra Universitária, 2014.

HILL, Leslie. Maurice Blanchot and fragmentary writing: a change of epoch. Disponível em: http://ndpr.nd.edu/news/35433-maurice-blanchot-and-fragmentary-writing-a-change-of-epoch/. 
Acesso em: 17 Nov. 2013.

HILST, Hilda. Teatro Completo. São Paulo: Globo, 2008.

KAC, Eduardo. Telepresença e Bioarte. São Paulo: Edusp, 2013.

KLOSSOWSKI, Pierre. Nietzsche y El Circulo Vicioso. Tradução de Néstor Sánchez e Teresa Wangeman. Barcelona: Seix Barral, 1972.

LACOUE-LABARTHE, P; NANCY, J.-L. L'Absolu Littéraire - théorie de la littérature du romantisme allemand. Paris: Seuil, 1978.

LEÃO, Rodrigo de Souza. Todos os Cachorros são azuis. Rio de Janeiro: 7Letras, 2010. . O esquizoide - coração na boca. Rio de Janeiro: Record, 2011.

LISPECTOR, Clarice. Água Viva. São Paulo: Círculo do Livro, 1973.

LOPES, Silvina Rodrigues. Sobretudo as vozes. Lisboa: Vendaval, 2004.

MACHADO, Roberto. Foucault, a filosofia e a literatura. Rio de Janeiro: Jorge Zahar Ed., 2005. . Nietzsche e a Verdade. São Paulo: Graal, 1999.

MALlO, Agustin Fernández. Nocilla dream. Tradução de Joana Angélica d'Avila Melo. São Paulo: Companhia das Letras, 2013. . Nocilla experience. Tradução de Joana Angélica d'Avila Melo. São Paulo: Companhia das Letras, 2013.

MÁRCIO-ANDRÉ. Ensaios Radioativos. Rio de Janeiro: Confraria do Vento, 2008.

MARTON, Scarlett. Nietzsche - das forças cósmicas aos valores humanos. São Paulo: Brasiliense, 1990.

MELVILLE, Herman. Bartleby, o escrivão. Uma história de Wall Street. Tradução de Cássia Zanon. Rio de Janeiro: Nova Fronteira, 2009.

MORAES, Fabiana de; QUEIROZ, Andre; VELASCO E CRUZ, Nina (orgs.). Barthes/Blanchot: um encontro possível? Rio de Janeiro: 7Letras, 2007.

MORAES, Reinaldo. Tanto Faz \& Abacaxi. São Paulo: Companhia das Letras, 2011.

NANCY, Jean-Luc. La Communauté Desœuvrée. Paris: Christian Bourgois Éditeur, 1999. 
NEHAMAS, Alexander. Nietzsche: la vida como Literatura. Tradução de Ramón J. García. Madrid: Turner, 2002.

NETO, Torquato. Torquália: do lado de dentro - obra reunida de Torquato Neto vol. 1. Rio de Janeiro: Rocco, 2004.

NIETZSCHE, Friedrich. A Gaia Ciência. Tradução de Paulo César de Souza. São Paulo: Companhia das Letras: 2001.

. Escritos sobre Educação. Tradução de Noéli Correia de Melo Sobrinho.

Rio de Janeiro: Ed. PUC-RJ; São Paulo: Loyola, 2003.

. Vontade de Potência. Tradução de Mário Ferreira dos Santos. Petrópolis:

Vozes, 2011.

NOLL, João Gilberto. Mínimos, Múltiplos, Comuns. Brasília: Francis, 2003.

PARENTE, André (org.). Tramas da Rede: novas dimensões filosóficas, estéticas e políticas da comunicação. Porto Alegre: Sulina, 2004.

PELBART, Peter Pál. Da clausura do fora ao fora da clausura: loucura e desrazão. São Paulo: Iluminuras, 2009.

PEREC, Georges. A arte e a maneira de abordar seu chefe para pedir um aumento. Tradução de Bernardo Carvalho. São Paulo: Companhia das Letras, 2010.

PIVA, Roberto. Paranóia. São Paulo: IMS, 2000.

POMPEU, Renato. A Greve da Rosa. São Paulo: Alfa-Omega, 1980.

. A Saída do Primeiro Tempo. São Paulo: Alfa-Omega, 1978. . Memórias da Loucura. São Paulo: Alfa-Omega, 1983.

. Quatro-Olhos. São Paulo: Alfa-Omega, 1976.

PUCHEU, Alberto. A Fronteira Desguarnecida - Poesia reunida (1993-2007). Rio de Janeiro: Azougue Editorial, 2007.

RICKELS, Laurence A. (org.). Looking after Nietzsche. Nova Iorque: State University of New York Press, 1990.

SANT'ANNA, André. Inverdades. Rio de Janeiro: 7Letras, 2009. 
SALOMÃO, Waly. Poesia Total. São Paulo: Companhia das Letras, 2014.

SCHLEGEL, Friedrich. Conversa sobre Poesia e outros fragmentos. Tradução de Victor-Pierre Stirnimann. São Paulo: Iluminuras, 1994.

. O Dialeto dos Fragmentos. Tradução de Márcio Suzuki. São Paulo:

Iluminuras, 1997.

TABAROVSKY, Damian. Literatura de izquierda. Rosario: Beatriz Viterbo, 2004.

VASCONCELOS, Mauricio Salles. Blanchot, paradoxo plural. Caligrama, Belo Horizonte, n.07, p. 143-160, 2001.

. Espiral Terra: poéticas contemporâneas de língua portuguesa. São

Paulo: Annablume, 2013.

- Genealogias da Literatura ou Imaginar Foucault. In: PASSOS,

Izabel F.; BELO, Fábio (orgs.). Na Companhia de Foucault - 20 anos de ausência. Belo Horizonte:

FALE/UFMG, v.1, 2004, p.66-73.

XAVIER, Valêncio. Rremembranças da menina de rua morta nua: e outros livros. São Paulo:

Companhia das Letras, 2006. 